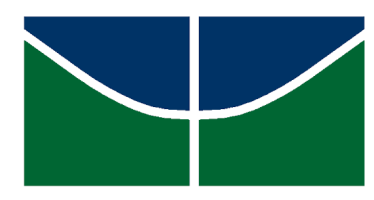

Universidade de Brasília

Instituto de Relações Internacionais

Programa de Pós-Graduação em Relações Internacionais

Mestrado em Relações Internacionais

\title{
A IMPOSIÇÃO DO ALINHAMENTO: \\ a política externa dos governos Dutra e Vargas (1946-1954)
}

DANIEL COSTA GOMES 


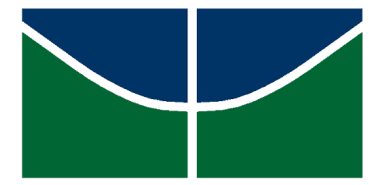

Universidade de Brasília

Instituto de Relações Internacionais

Programa de Pós-Graduação em Relações Internacionais

Mestrado em Relações Internacionais

A IMPOSIÇÃO DO ALINHAMENTO:

a política externa dos governos Dutra e Vargas (1946-1954)

\section{DANIEL COSTA GOMES}

Dissertação apresentada ao Programa de PósGraduação em Relações Internacionais da Universidade de Brasília como requisito parcial para a obtenção do título de Mestre em Relações Internacionais.

Orientador: Prof. Dr. Antônio Carlos Lessa. Co-orientador: Prof. Dr. Thiago Gehre Galvão. 


\section{AGRADECIMENTOS}

A Tarsila, que contribuiu direta e indiretamente para a elaboração deste trabalho e que me proporcionou apoio e incentivo incondicionais.

A Alfrêdo e Germana, que serviram de inspiração para essa trajetória e a quem sou extremamente grato pela generosidade.

A Danilo, que me acompanha aonde for.

A Héctor, Iury, Giuliana, Cristina, Igor e Ianes, que enriqueceram essa jornada.

A Jaidir, Edilene, Elisana e Priscila, que me acolheram genuinamente.

A Daniel, Diego, François, Leonardo, Mateus, Rosana e Thaciano, cuja amizade nem o tempo, nem a convivência conseguiram afastar.

A Alexandre Moreli, que lançou as primeiras luzes sobre este trabalho e, em nome de quem, agradeço à Fundação Getúlio Vargas e, especificamente, ao Centro de Pesquisa e Documentação de História Contemporânea do Brasil.

A Demétrio Weber, cujo humanismo é inspirador e, em nome de quem, agradeço à Organização das Nações Unidas para a Educação, a Ciência e a Cultura.

A Sombra Saraiva, Pio Penna, Cristina Inoue, Vanessa Bottazzini, em nome de quem agradeço à Universidade de Brasília e, especificamente, ao Instituto de Relações Internacionais.

À Coordenação de Aperfeiçoamento de Pessoal de Nível Superior, que me proporcionou uma bolsa de estudos.

AAntônio Carlos Lessa e Thiago Gehre Galvão, que me orientaram neste trabalho. 


\section{RESUMO}

O presente trabalho analisa a política externa adotada pelos governos de Eurico Dutra (1946-1950) e de Getúlio Vargas (1951-1954), valendo-se de fontes primárias e secundárias. A hipótese defendida é a de que, durante esses dois governos, a política externa brasileira foi caracterizada pela "imposição do alinhamento". Consequentemente, influenciada por forças internas e externas, a política alinhada aos Estados Unidos impôs-se como a opção efetivamente viável ao Brasil desses dois presidentes. No desenvolvimento dessa caracterização, debatem-se os conceitos tradicionais para a interpretação da política externa daqueles dois governos. As premissas desses conceitos são analisadas e interpretadas segundo estudos recentes desenvolvidos no âmbito da História Mundial, da História do Brasil, da História das Relações Internacionais, da História da Política Exterior do Brasil, da Economia Mundial e da Economia Brasileira.

Palavras-chave: Política Externa Brasileira. História das Relações Internacionais. História do Brasil. Eurico Dutra. Getúlio Vargas. 


\begin{abstract}
This paper analyzes the foreign policy adopted by the governments of Eurico Dutra (1946-1950) and of Getúlio Vargas (1951-1954), resorting to primary and secondary sources. The hypothesis it defends is that, during these two governments, Brazilian foreign policy was characterized by the "imposition of alignment". Consequently, influenced by internal and external forces, the policy of alignment to the United States imposed itself as the effectively viable option to the Brazil of theses two presidents. Along the development of that characterization, the traditional concepts to the interpretation of the foreign policy of those two governments are debated. The premises of these concepts are analyzed and interpreted according to recent studies developed in the field of World History, Brazilian History, International Relations History, Brazilian Foreign Policy History, World Economy, and Brazilian Economy.
\end{abstract}

Keywords: Brazilian Foreign Policy. Brazilian History. International Relations History. Eurico Dutra. Getúlio Vargas. 


\section{LISTA DE SIGLAS}

ABDE Associação Brasileira de Escritores

AGNU Assembleia Geral das Nações Unidas

AHI Arquivo Histórico do Itamaraty (Rio de Janeiro)

AHMRE-B Arquivo Histórico do Ministério das Relações Exteriores - Brasil

CIA Central Intelligence Agency

CMBEU Comissão Mista Brasil - Estados Unidos para o Desenvolvimento Econômico

CPDOC Centro de Pesquisa e Documentação de História Contemporânea do Brasil

FEB Força Expedicionária Brasileira

FGV Fundação Getúlio Vargas

FMI Fundo Monetário Internacional

FRUS Foreign Relations of the United States

FTA Fast Track Authority

GATT General Agreement on Tariffs and Trade

GV Arquivo Getúlio Vargas, CPDOC

IBGE Instituto Brasileiro de Geografia e Estatística

MNA Movimento dos Não Alinhados

OA Arquivo Oswaldo Aranha, CPDOC

OEA Organização dos Estados Americanos

OMC Organização Mundial do Comércio

PEI Política Externa Independente

PIB Produto Interno Bruto

PRE Pragmatismo Responsável e Ecumênico

PSD Partido Social Democrático

PSB Partido Socialista Brasileiro

PTB Partido Trabalhista Brasileiro

RTAA Reciprocal Trade Agreements Act

SUMOC Superintendência da Moeda e do Crédito

TIAR Tratado Interamericano de Assistência Recíproca

TSE Tribunal Superior Eleitoral 
UND União Democrática Nacional

UNE União Nacional dos Estudantes

USIA United States Information Agency 


\section{SUMÁRIO}

Introdução

Capítulo I - Política externa brasileira no pós-1945: imposição do alinhamento 14

1.1. Imposição do alinhamento: parâmetros e definição 15

1.2. O mundo de 1945: nasce uma nova ordem mundial 18

$\begin{array}{ll}\text { 1.2.1. A "era das superpotências" } & 19\end{array}$

1.2.2. A decadência europeia 20

1.2.3. A nova ordem econômica ocidental 23

1.2.3.1. Analisando o adjetivo ocidental 23

1.2.3.2. Analisando a nova ordem $\quad 24$

1.2.4. Balanço da nova arena internacional 30

1.3. O Brasil de 1945: a dicotomia entre Estado e governo 31

1.4. A insustentabilidade política do governo Vargas 34

1.4.1. Autonomia da política em relação à economia 35

1.4.2. Opinião pública e sociedade civil organizada 37

1.4.3. Os passos finais da transição 42

1.5. O novo e inescapável projeto político: liberalismo 43

1.6. Conclusões parciais $\quad 47$

Capítulo II - Imposição do alinhamento: o governo Dutra 50

2.1. Elementos do contexto internacional para a imposição do alinhamento $\quad 51$

2.1.1. A bipolaridade como imposição 53

2.1.2. O arranjo ocidental $\quad 60$

2.1.2.1. O domínio dos Estados Unidos $\quad 60$

2.1.2.2. A força do liberalismo 64

2.1.3. O grau de liberdade no interior do bloco ocidental 65

2.2. Exercício do alinhamento $\quad 67$

2.2.1. Os chanceleres de Dutra 69

2.2.1.1. João Neves da Fontoura $\quad 70$

2.2.1.2. Raul Fernandes $\quad 72$

2.2.3. Da regra geral para as medidas específicas $\quad 74$

$\begin{array}{ll}\text { 2.3. Resistência ao alinhamento } & 78\end{array}$

2.3.1. A racionalidade do alinhamento $\quad 79$

2.3.1.1. A "ilusão" política $\quad 80$

2.3.1.2. A "ilusão" econômica $\quad 81$

2.3.2. A prática da resistência $\quad 83$

2.3.2.1. No âmbito político 83

2.3.2.2. No âmbito econômico $\quad 85$

$\begin{array}{ll}\text { 2.4. Conclusões parciais } & 87\end{array}$

Capítulo III - Imposição do alinhamento: o governo Vargas 90

3.1. Notas conceituas: Dutra e Vargas 91

3.2. A "imposição do alinhamento" pelo contexto internacional 92 
3.2.1. A Guerra da Coreia 93

3.2.2. A ascensão de Eisenhower e Kruschev 95

3.2.3. A emergência de novos polos de poder 98

3.3. Retorno de Vargas, continuação do alinhamento 100

3.3.1. Configuração política nacional após as eleições de $1950 \quad 101$

3.3.2. A "barganha nacionalista" e o "pragmatismo impossível" 104

3.3.3. Resistência ao alinhamento 104

3.3.3.1. O palco: a Conferência de Washington 107

3.3.3.2. O meio: a Comissão Mista Brasil - Estados Unidos 109

3.3.3.3. Outras manifestações de resistência 110

3.3.4. Exercício do alinhamento 112

3.3.4.1. Os chanceleres de Vargas $\quad 113$

3.3.4.2. Da regra geral para as medidas específicas $\quad 116$

3.4. Conclusões parciais 120

$\begin{array}{ll}\text { Conclusão } & 123\end{array}$

$\begin{array}{ll}\text { Bibliografia } & 128\end{array}$

$\begin{array}{ll}\text { Anexos } & 145\end{array}$ 


\section{INTRODUÇÃO}

O presente trabalho insere-se no campo de estudo da História das Relações Internacionais e, nesta, na História da Política Exterior do Brasil, especificamente. Como tal, seu objeto de análise é a política externa adotada pelos governos de Eurico Dutra (1946-1950) e de Getúlio Vargas (1951-1954).

A hipótese que se pretende comprovar é que, durante esses dois governos, a política externa brasileira poderia ser entendida pela "imposição do alinhamento". Assim, propõe-se que, influenciada por forças internas e externas, a política alinhada aos Estados Unidos ter-seia imposto como a opção efetivamente viável ao Brasil desses dois presidentes. Nesse sentido, pode-se mesmo argumentar que o alinhamento se teria colocado independentemente de qual personagem estava à frente do Catete.

O desenvolvimento dessa hipótese justifica-se como uma tentativa de avançar o conhecimento científico. Afinal, diante da vasta literatura sobre a política externa de Dutra (1946-1950) e a de Vargas (1951-1954), questiona-se se não haveria espaço para outras leituras. Procurando argumentar que há, sim, espaço, intenta-se desenvolver interpretação que, beneficiando-se da literatura existente, se esforça para acrescentar novos pontos de vista.

Em relação a essa literatura, no caso de Dutra, há uma tendência de interpretar o alinhamento que seu governo adotou como inépcia política. Assim, a política externa alinhada aos Estados Unidos não teria angariado recompensas (MOURA, 1990), sendo um passo fora da cadência na trajetória desenvolvimentista brasileira (CERVO, 2008a, p. 46; BUENO; CERVO, 2012, p. 394). Nesse sentido, a adoção do alinhamento teria sido consequência antes de considerações ideológicas que de ponderações quanto ao desenvolvimento nacional (PINHEIRO, 2004, p. 65). Inclusive, tal orientação política teria resultado da ausência de autonomia decisória pelo Brasil (CERVO, 2008a, p. 72), interpretação que lança dúvidas sobre a própria independência do país.

Há, ainda, a tendência de associar o alinhamento aos Estados Unidos a uma falha de caráter de Dutra. Dessa forma, a política externa alinhada seria o reflexo de um presidente subserviente (VISENTINI, 2013a, p. 21), "sem qualquer avaliação objetiva e deixando de lado os próprios interesses brasileiros". Por isso, seria entreguista (VISENTINI, 2013b, p. 198). Segundo fórmulas variadas, essa subserviência é retratada em outros autores também, 
como Cervo (2007) e Bandeira $(1973,2003)$. Um dos sinais dessa subserviência seria o suposto retorno à vocação agrícola como modelo econômico brasileiro (MOURA, 2012; SKIDMORE, 1982; VISENTINI, 2013b).

Uma premissa partilhada, implícita ou explicitamente, pela maior parte dessas interpretações é a de que haveria outras possibilidades de inserção internacional. Afinal, se há um julgamento tão depreciativo é porque Dutra poderia ter feito outras escolhas. Assim, o alinhamento teria sido uma opção deliberada de seu governo. A ideia de "imposição do alinhamento", no entanto, procura debater essa premissa, propondo-se que, como não haveria alternativas efetivamente exequíveis ao alinhamento, o papel de Dutra teria sido praticamente irrelevante para a conformação dessa política. Assim, este trabalho desenvolve caminho sugerido por Lima (2006, p. 46), que questiona "governo Dutra: alternativa equivocada ou ausência de alternativas?".

Além disso, o conceito de "imposição do alinhamento" procura incorporar ao estudo da História da Política Exterior do Brasil os avanços verificados na História Econômica do Brasil. Afinal, vários estudos recentes (BASTOS, 2012; VIANNA, 2014; ABREU, 2013; GONÇALVES, 2016) apontam para conclusões contrárias a premissas que balizam interpretações da política externa de Dutra. Por exemplo, Abreu (2013, p. 205) registra que, nesse governo, o PIB industrial cresceu a uma média anual de 11,4\%, o que não parece coerente com a ideia de retorno à vocação agrícola. Gonçalves $(2016$, p. 8), por sua vez, informa que, com Dutra, a taxa média de crescimento econômico brasileiro foi de 7,6\%, índice que não aparenta refletir um governo subserviente, desprovido de autonomia decisória, sem considerações com os interesses nacionais.

No caso de Vargas, apesar de a sua política externa também ter sido alinhada, a caracterização é praticamente oposta. Nesse sentido, o retorno de Getúlio ao Catete teria implicado a retomada do paradigma desenvolvimentista (CERVO, 2008a). Em consequência, após o hiato liberal que teria definido o governo Dutra (BUENO; CERVO, 2012; CERVO, 2008a), o governo Vargas ter-se-ia caracterizado pela busca da barganha nacionalista (VISENTINI, 1996; VISENTINI, 2013b).

A política externa brasileira, dessa forma, retomaria sua racionalidade, de modo que a relação do país com as grandes potências, em especial com os Estados Unidos, voltaria a apresentar caráter instrumental, visando ao desenvolvimento econômico nacional 
(PINHEIRO, 2004, p. 29). O alinhamento brasileiro, então, teria retomado seu formato pragmático, segundo define Pinheiro (2004, p. 66-65).

Essa interpretação persiste, sendo ecoada em outras obras (CERVO, 2007; CERVO, 2008a; BANDEIRA, 1973; BANDEIRA, 2003), a despeito do reconhecimento de que, no governo Vargas, o pragmatismo foi impossível (HIRST, 1990). Ainda, o retorno de Vargas à Presidência continua a ser caracterizado pela retomada do desenvolvimentismo e apresentado em oposição ao governo Dutra, embora as taxas médias anuais de crescimento econômico e de expansão industrial deste tenham sido maiores $(7,6 \%$ e $11,4 \%$, respectivamente) que as de Getúlio (6,2\% e 7,3\%, respectivamente). Igualmente, a política externa adotada por Vargas permanece sendo conceituada como antítese da implementada por Dutra, a despeito de admitir-se que, durante os anos desses dois governos, o alinhamento foi inevitável (PINHEIRO, 2004, p. 27).

Diante desse cenário contraditório, a ideia de "imposição do alinhamento" procura ressaltar as semelhanças entre essas duas presidências, derivando-lhes uma linha de continuidade - nomeadamente, a política externa alinhada, que, argumenta-se, se teria imposto independentemente do presidente à frente do Catete. Dessa forma, o objetivo deste trabalho não é proceder-se a uma crítica da natureza do tipo de inserção internacional do Brasil, nem dos impactos que tal tipo de inserção exerceu sobre o desenvolvimento econômico nacional.

Objetiva-se, sim, analisar como se manifestou o alinhamento brasileiro aos Estados Unidos no imediato pós-1945. Ante a semelhança desse alinhamento durante os governos Dutra e Vargas, o conceito de "imposição do alinhamento" dá continuidade à hipótese de Doratioto e Vidigal (2014, p. 71) de que, em seu segundo governo, "Vargas foi levado à adoção de uma política externa que se aproximava mais daquela adotada por Dutra do que da implementada da era Vargas (1930-1945)", quando se empreendeu a equidistância pragmática (MOURA, 1980).

Para tentar comprová-lo, o presente trabalho divide-se em três capítulos. No primeiro, analisam-se as transformações que caracterizavam o Brasil e o mundo na primeira metade da década de 1940. Como consequência, argumenta-se que essas transformações teriam resultado em um "clamor liberal", que constituiria o fundamento do qual emanariam o governo e o 
próprio regime político brasileiros de 1946 . Assim, o liberalismo ${ }^{1}$ seria a tônica a ser legada a esse governo e regime.

No segundo capítulo, o governo Dutra é analisado, com vistas a analisar como se materializou o "clamor liberal" que the havia sido legado e que the constituía a própria justificativa. Diante de tal cenário, a "imposição do alinhamento" teria emergido como consequência lógica para a política externa brasileira entre os anos 1946 e 1950. A propósito, embora tenha durado até o dia 31 de janeiro de 1951, o governo Dutra é mencionado neste trabalho como vigente entre 1946 e 1950; caso seja necessário referir-se à sua atuação como presidente em 1951, isso é explicitado.

No terceiro capítulo, por fim, o objeto de análise é o governo Vargas, e o objetivo é argumentar que a "imposição do alinhamento" também se teria verificado nesse período. A propósito, neste trabalho, "governo Vargas" equivale à segunda passagem de Getúlio na Presidência, entre 1951 e 1954; na eventualidade de ser necessário referir-se à primeira passagem, isso é evidenciado.

Todos esses três capítulos são estruturados de modo a contemplar as esferas internacional e nacional, pois, como dito, argumenta-se que a "imposição do alinhamento" teria resultado de influências domésticas e estrangeiras. Na esfera nacional especificamente, analisam-se os âmbitos político e econômico. No âmbito político, são investigadas iniciativas de política doméstica e de política externa.

Essa estrutura perpassa os três capítulos, mas é fundamentalmente desenhada para o segundo e o terceiro capítulos. Afinal, a justificativa primária desse arranjo é possibilitar a comparação entre os governos Dutra e Vargas segundo parâmetros semelhantes. Sua justificativa secundária é ilustrar que, em coerência com o "clamor liberal" do período, o alinhamento se manifestou em diversos setores, como nas políticas doméstica, externa e econômica. De tal forma, reforça-se a ideia de "imposição do alinhamento", que não seria uma mera casualidade, mas uma orientação geral a guiar esses governos.

\footnotetext{
${ }^{1}$ É difícil caracterizar o liberalismo, que pode assumir uma variedade extremamente ampla de significados. No caso do Brasil do pós-1945, o liberalismo foi antes de tudo retórico, instrumental, utilizado como discurso político. Além da dimensão retórica, esse liberalismo à brasileira assumiu contornos essencialmente econômicos, de modo que não implicou necessariamente ganhos em termos de liberdades civis, direitos humanos, garantias individuais. Inclusive, não é esse o objeto do presente trabalho, mas como se deu o alinhamento externo aos Estados Unidos durante os governos Dutra e Vargas. De toda forma, pode-se argumentar que o liberalismo, principalmente econômico, já se colocava sobre a política brasileira há bastante tempo - segundo alguns, desde a própria fundação do Brasil. Assim, o liberalismo poderia ser interpretado como uma espécie de força profunda (RENOUVIN, 1953; DUROSELLE; RENOUVIN, 1967) sobre a política brasileira.
} 
Por oportuno, registra-se que "orientação geral" não significa "orientação de sempre", como se os governos Dutra e Vargas tivessem sido homogeneamente alinhados nas respectivas iniciativas, políticas e atitudes. Dessa forma, este trabalho também é estruturado a partir da premissa de que os dois governos foram complexos, de modo que a política externa alinhada comportou nuances. Em ambas as presidências, houve, inclusive, iniciativas, políticas e atitudes que estavam em desacordo com interesses norte-americanos. Mesmo assim, apesar dessas manifestações pontuais de resistência ao alinhamento, a política externa alinhada ter-se-ia imposto, reforçando a ideia de "imposição alinhamento".

Assim, para capturar essas complexidades e para evitar simplificações, a presente dissertação procura elaborar uma interpretação abrangente acerca dos governos Dutra e Vargas. São analisadas manifestações que ilustram tanto a orientação geral do alinhamento quanto resistências pontuais a esse alinhamento. Naturalmente, não se pretende (nem se conseguiria) esgotar essas manifestações, registrando-lhes todas neste trabalho. Objetiva-se, sim, recorrer a essas manifestações na medida de sua utilidade para o desenvolvimento e a corroboração do conceito de "imposição do alinhamento", capturando-lhe as nuances.

Em relação às fontes, por fim, o presente trabalho recorre a fontes secundárias. Nesse sentido, são utilizados artigos e livros sobre história mundial, história brasileira, política internacional, política externa brasileira, economia mundial, economia brasileira, direito internacional público, direito constitucional brasileiro.

Também se recorre a fontes primárias. Assim, são utilizados jornais da época; documentos pessoais presentes nos arquivos Eurico Dutra (ED), Getúlio Vargas (GV) e Oswaldo Aranha (OA) constantes no Centro de Pesquisa e Documentação de História Contemporânea do Brasil (CPDOC), da Fundação Getúlio Vargas (FGV); correspondência diplomática e relatórios oficiais constantes no Arquivo Histórico do Ministério das Relações Exteriores (AHMRE, Brasília); correspondência diplomática e relatórios oficiais constantes no Office of the Historian do Foreign Relations of the United States (FRUS); relatórios sobre eleições, bem como programas e manifestos de partidos políticos constantes na Coordenaria de Gestão Documental do Tribunal Superior Eleitoral (TSE); discursos políticos e mensagens oficiais constantes na Biblioteca da Presidência da República [do Brasil], bem como nas Truman Library e Eisenhower Library. 
Capítulo I

\section{Política externa brasileira no pós-1945: a imposição do alinhamento}

A política externa brasileira do pós-1945 tem sua primeira manifestação no governo do general Eurico Gaspar Dutra (1946-1950). Esse período é, tradicionalmente, conceituado como alinhamento sem recompensas, segundo a chave analítica cunhada por Gerson Moura (1990). Nesse conceito, estão registradas, explicitamente, duas características fundamentais.

A primeira característica é a estratégia adotada pelo Brasil, no imediato pós-Segunda Guerra Mundial, de atrelar sua política externa aos Estados Unidos como forma de maximizar os ganhos nacionais - essa é a interpretação, por exemplo, de Cervo (2008a, p. 46-47); há, no entanto, autores, como Visentini (2013b, p. 198-200), que não mencionam esse caráter instrumental, como se o alinhamento de Dutra tivesse sido apenas uma liberalidade gratuita, desmotivada e sem propósito. A segunda característica explicitada pelo conceito é o fracasso dessa estratégia. Por isso, alinhamento sem recompensas (MOURA, 1990).

Essas duas características balizam a interpretação de que a política externa do primeiro governo após a Era Vargas (1930-1945) constituiria uma espécie de "passo fora da cadência"2, quando analisada diacrônica e comparativamente no contexto dos "sessenta anos de política externa"3 desenvolvimentista. Assim, o imediato pós-1945 teria assistido a um descolamento da tendência observada entre os anos 1930 e 1989 de prevalência do "paradigma nacionaldesenvolvimentista" (CERVO, 2008a), pois lhe faltariam elementos fundamentais desse paradigma. Notadamente, sua política externa seria desprovida de autonomia decisória, já que estaria alinhada aos Estados Unidos; e seu projeto econômico seria liberal, em contraste com o nacionalismo econômico adotado pelas grandes potências (CERVO, 2008a, p. 72).

Argumenta-se, neste capítulo, que é necessário sejam feitas ressalvas a essa caracterização. Não se pretende negar que a política externa brasileira no pós-1945 tenha sido alinhada aos Estados Unidos, o que parece ser uma questão factual, praticamente imune a revisões interpretativas. Objetiva-se, sim, argumentar que esse modelo analítico-interpretativo

\footnotetext{
${ }^{2}$ Essa expressão é utilizada, originalmente, por Bueno e Cervo (2012, p. 394) para qualificar a política externa do governo Castelo Branco. A utilização, no entanto, dessa expressão para a política externa de Dutra também é possível, pois o próprio Cervo (2008a, p. 46) estabelece essa comparação.

${ }^{3}$ Expressão que entitula obra organizada por José Augusto Guilhon Albuquerque (1996), analisando a política externa brasileira entre 1930 e 1990, que seria marcada pela tônica desenvolvimentista.
} 
(política alinhada de Dutra) é embasado, explícita ou implicitamente, em uma premissa frágil, nomeadamente a de que havia opções alternativas viáveis ao alinhamento.

É diante desse cenário que se propõe o conceito de "imposição do alinhamento" para caracterizar a política externa brasileira do imediato pós-Era Vargas. Essa conceito sintetiza a ideia de que, após 1945, fatores externos e internos restringiram as opções de inserção internacional do Brasil. Isso significa que a política externa alinhada seria adotada independentemente do presidente que viesse a assumir em 1946. Assim, o alinhamento aos Estados Unidos, mais que uma opção pessoal de Dutra, foi uma imposição do período.

\subsection{Imposição do alinhamento: parâmetros e definição}

O esforço de elaboração do conceito de "imposição do alinhamento" tem por parâmetros duas premissas. A primeira é a ideia de que definir a política externa brasileira de Dutra ou de qualquer outro governo do Brasil independente como "desprovida de autonomia decisória" (CERVO, 2008a, p. 72) não tem precisão técnica. A única forma de aceitar esse tipo de caracterização é como uma figura de linguagem de força retórica.

Afinal, segundo o Direito Internacional, a perda da autonomia decisória em política externa só ocorre em Estados vassalos, protetorados, Estados clientes, Estados satélites e Estados associados ${ }^{4}$ (MELLO, 2004, p. 381-385). Nenhuma dessas situações jurídicopolíticas foi observada na história do Brasil independente, a partir de 1822 . Consequentemente, adotando-se rigor técnico, não se pode dizer que a política externa brasileira, em qualquer momento, se viu "desprovida de autonomia decisória" (CERVO, 2008a, p. 72). Isso implica que as formas de inserção internacional adotadas pelo Brasil resultaram do exercício do poder soberano nacional. Em outros termos, todas as manifestações da política externa brasileira decorreram da autonomia decisória nacional.

A segunda premissa, por sua vez, é a de que, muitas vezes, as análises acerca da política externa brasileira do pós-Era Vargas reproduzem, indistintamente, as caracterizações já estabelecidas - fenômeno conceituado por Durossele (2000) como reificação. Com isso, não se quer que todo trabalho sobre o pós-1945 deva procurar contestar essas caracterizações.

\footnotetext{
4 Todas essas entidades eram formas de Estado semissoberano e que, por isso, têm autonomia e atuação internacional restritas (MELLO, 2004, p. 381-385). Para definição mais abrangente de cada uma dessas entidades, consultar Anexo 01.
} 
Ressalta-se, sim, a importância de, ao se utilizar dessas caracterizações estabelecidas, não apenas reproduzi-las, mas investigar sua fundamentação - até para compreendê-las melhor.

Nesse sentido, verifica-se que, na literatura, são utilizadas, exaustivamente, fórmulas como alinhamento sem recompensas (MOURA, 1990), entreguista (VISENTINI, 2013b), hiato liberal (CERVO, 2008a) para definir a política externa brasileira do imediato pós-1945. Muitas vezes, no entanto, essa utilização é uma reificação (DUROSELLE, 2000), de modo que os conceitos são empregados acriticamente, principalmente por meio de uma visão retrospectiva. Assim, julga-se essa política externa com os olhos de hoje, ignorando-se os fundamentos e os condicionantes históricos internos e externos que foram postos à época e que levaram à adoção daquela estratégia.

Partindo-se desse diagnóstico, argumenta-se que a primeira etapa necessária para se compreender a política externa brasileira do pós-1945 é apresentar esses fundamentos e condicionantes históricos postos à época. Por isso, serão apresentadas e analisadas, ao longo deste capítulo, as transformações ocorridas nos âmbitos mundial e nacional.

Essas mudanças, conforme se argumentará, foram de magnitude tão expressiva que a política externa brasileira se viu constrangida em termos de opções. Alinhar-se aos Estados Unidos impôs-se como a consequência lógica daquelas transformações. Daí, vem a ideia de "imposição do alinhamento".

Neste trabalho, o que se entende por "imposição do alinhamento" é uma situação em que não havia alternativas exequíveis ao alinhamento. Essa situação foi derivada das variáveis (internas e externas) que compuseram o processo decisório relativo à formação da política externa nacional da época. Não decorreu, então, de nenhuma força estrangeira que impôs sua vontade sobre uma nação submetida. Ao contrário, o alinhamento foi resultante de uma decisão soberana perante um quadro de falta de opções alternativas viáveis. O termo "imposição", dessa forma, refere-se justamente a isto: inexistência de alternativas efetivamente concretas. Assim, como não havia opções viáveis, o alinhamento impôs-se, e não foi imposto (por uma potência imperial estrangeira).

A partir dessa definição, sobressai-se a necessidade de se analisarem as variáveis (externas e internas) que levaram à "imposição do alinhamento". No âmbito internacional, a vitória dos Aliados na Segunda Guerra Mundial implicou a derrota dos regimes autoritários. Isso foi instrumentalizado, no Brasil, como impulso ao ideário liberal, que exigia a 
redemocratização do país. A conformação de uma nova ordem mundial, caracterizada, inicialmente, pela era das superpotências (WATSON, 1992), também serviu de impulso às forças liberais brasileiras. Afinal, diante das superpotências vitoriosas na Segunda Guerra Mundial, era com os Estados Unidos que a sociedade brasileira tinha mais afinidade cultual e ideológica - e mesmo política, principalmente, a partir da gestão do Barão do Rio Branco (1902-1912), quando se formou a aliança não escrita (BURNS, 2003).

Ainda no marco da bipolaridade que emergia no pós-1945, o bloco comunista, o outro polo dessa nova ordem, era profundamente rejeitado pela maior parte da sociedade brasileira (MENDES, 2012, p. 117). Isso implicou que o perigo comunista se tornou um referencial negativo - a ser combatido, evitado, rejeitado - em torno do qual gravitou a ação interna e externa do Brasil. Assim, as transformações internacionais exerceram influência significativa para a assimilação do liberalismo como princípio da política externa brasileira.

No âmbito nacional, por sua vez, o desgaste do longo governo Vargas, que estava no poder desde a Revolução de 1930, alimentava a oposição política e, principalmente, ideacional a esse regime. Afinal, embora os grupos oposicionistas a Getúlio fossem bastante heterogêneos político, social e ideologicamente, havia um denominador comum que unia a todos: a contestação ao autoritarismo.

Em termos ideacionais, a oposição a Vargas era traduzida em liberalismo, que, embora registrado no singular, assumia diversos formatos. Alguns exemplos de manifestação do liberalismo eram: a volta dos partidos políticos, a restauração da democracia, a liberdade de expressão, a liberdade de imprensa, a autonomia estadual. Independentemente do significado, havia um "clamor liberal" na sociedade brasileira. O ápice desse movimento foi a destituição de Getúlio Vargas, em 1945, e a emergência da República Liberal-Conservadora.

Diante desse cenário, argumenta-se que o governo Dutra nasceu, ideacionalmente, em oposição ao regime varguista autoritário - embora deste fossem oriundos muitos dos membros do novo governo, inclusive o próprio Dutra. Consequentemente, houve a "imposição do liberalismo" também por via do âmbito interno, uma vez que a própria justificativa para a fundação de uma nova ordem político-institucional no Brasil foi a oposição ao autoritarismo - ou a afirmação do liberalismo.

Sem essas considerações, a análise acerca da política externa brasileira do pós-1945 não consegue responder à seguinte pergunta: por que um militar autoritário, com inclinações 
ao fascismo ${ }^{5}$ e antipático aos Estado Unidos ${ }^{6}$ teria optado por uma política externa liberal, alinhada a esse país? A resposta a esse quase paradoxo é o argumento que se defende neste capítulo: em 1946, não havia opção alternativa efetivamente viável ao liberalismo. Assim, independentemente de quem ocupasse o Catete, as transformações que ocorriam nos cenários nacional e internacional levariam à adoção de uma política externa liberal, alinhada aos Estados Unidos. Por esse motivo, argumenta-se que houve a "imposição do alinhamento" à política externa brasileira no imediato pós-Segunda Guerra Mundial.

\subsection{O mundo de 1945: nasce uma nova ordem mundial}

Para se assimilar o padrão de política externa adotado pelo Brasil no pós-1945, é necessário, inicialmente, compreender o quadro internacional que foi posto ao país. Nesse sentido, é importante ter em vista que o ano de 1945 constituiu um marco de ruptura não apenas para a história brasileira, mas também para a história mundial, já que emergia uma nova ordem internacional. Esse contexto fundador - nos âmbitos interno e externo - teria influência significativa para a conformação do padrão de inserção internacional do Brasil, que se argumenta foi caracterizado pela "imposição do alinhamento" no período imediatamente posterior à Segunda Guerra Mundial.

Analisando-se, inicialmente, as transformações ocorridas no âmbito mundial, pode-se afirmar que duas consequências principais se seguiram ao fim da Segunda Guerra Mundial. A primeira foi a decretação de que os grupos (autoproclamados) liberais/democráticos, constituídos pelas forças Aliadas, haviam vencido a batalha ideológica contra os rivais (identificados como) autoritários/fascistas, constituídos pelas forças do Eixo. Como se verá em sessão seguinte, essa vitória ideológica teve impacto imediato sobre a política brasileira. A segunda consequência foi a passagem da sociedade internacional europeia para a sociedade internacional global (WATSON, 1992), ao que se decida a próxima seção.

\footnotetext{
${ }^{5}$ As caracterizações de Dutra como inclinado ao fascismo são abundantes na literatura, embora sob diversos formatos. Schwarcz e Starling (2015, p. 387) identificam Dutra como "próximo dos integralistas e notório admirador da Alemanha nazista". Visentini (2013a, p. 19) refere-se a Dutra como "o condestável do regime autoritário e ex-simpatizante do Eixo". Em linha similar, Svartman $(2009$, p. 8) registra que "tanto Dutra quanto Góes Monteiro eram notórios simpatizantes do Eixo".

${ }^{6}$ Comentando sobre o fechamento, em agosto de 1944, da Sociedade Amigos da América, Boris Fausto (2013, p. 105) informa: "Dutra, com sua antipatia pelos Estados Unidos, deu cobertura à ação repressiva".
} 


\subsubsection{A "era das superpotências"}

Por mais de quatro séculos (FRANK; GIRAULT; THOBIE, 1993, p. 90), as relações internacionais foram caracterizadas pelo que Watson (1992) conceituou de sociedade internacional europeia. Como o próprio nome sugere, essa foi a época na qual a hegemonia (coletiva ou individual) foi exercida por potências europeias. No século XIX, a sociedade internacional europeia alcançou seu auge, tornando-se mundial. Pela primeira vez na história da humanidade, todo o globo terrestre estava conectado por uma rede de relações econômicas e estratégicas (WATSON, 1992, p. 265).

Essa ordem mundial começou a ruir a partir do fim da Primeira Guerra Mundial (WATSON, 1992, p. 278). A Segunda Guerra Mundial, por sua vez, decretou seu colapso definitivo. Assim, a sociedade internacional europeia foi substituída por uma nova ordem, caracterizada como sociedade internacional global (WATSON, 1992).

A primeira manifestação dessa nova ordem mundial foi a era das superpotências, nomeadamente Estados Unidos e União Soviética (WATSON, 1992). Esses dois países saíram como os grandes vencedores da Segunda Guerra Mundial. Além de terem sido os que empreenderam os maiores esforços para derrotar as forças do Eixo, também foram os que melhor conseguiram instrumentalizar o conflito bélico como promotor do desenvolvimento interno. Assim, União Soviética e Estados Unidos alçaram-se ao topo da hierarquia mundial.

Gradativamente, no entanto, as duas superpotências passaram de aliadas na Segunda Guerra Mundial a rivais na nova ordem mundial. Em março 1946, em seu discurso Sinews of Peace, proferido no Westminster College, nos Estados Unidos, o ex-primeiro ministro britânico Winston Churchill anunciou a emergência de uma "cortina de ferro"7 "from Stettin in the Baltic to Triest in the Adriatic"'s. A partir de então, a Europa (e o mundo) passava a estar separada entre "pró-soviéticos" e "democracias ocidentais"

Apesar de anunciada por Churchill, essa divisão bipolar só ganharia contornos efetivos de rivalidade com a Doutrina Truman, lançada pelo discurso do presidente norte-americano

\footnotetext{
${ }^{7}$ Embora a expressão "cortina de ferro" tenha alcançado popularidade com Churchill, a partir do discurso Sinews of Peace, sua origem é anterior. Mendes (2012), por exemplo, lembra que Joseph Goebbles havia empregado a expressão em 1944. Antes mesmo dessa data, a expressão já tinha sido empregada várias vezes. Está presente, por exemplo, no livro Through Bolshevik Russia, de Ethel Snowden, de 1920. Não é possível, no entanto, precisar a origem exata da expressão, podendo ser, inclusive, muito anterior.
}

${ }^{8}$ Churchill (apud CHURCHILL, 2003, p. 420). 
no Congresso, em 12 de março de 1947. O contexto imediato dessa doutrina foram as guerras na Turquia e na Grécia. Nelas, os soviéticos enfrentavam forças locais que contavam com o apoio inglês. O Reino Unido, no entanto, sofria os efeitos econômicos derivados da Segunda Guerra Mundial. Assim, em fevereiro de 1947, o embaixador britânico nos Estados Unidos informou ao Departamento de Estado que o Reino Unido não conseguiria mais apoiar nem a Grécia, nem a Turquia. Por isso, solicitou auxílio norte-americano (WINKLER, 2003).

Em decorrência, Harry Truman requisitou autorização do Congresso para que os Estados Unidos apoiassem "free peoples who are resisting attempted subjugation by armed minorities or by outside pressures" ${ }^{\prime 9}$. A bipolaridade estava definida, de modo que "nearly every nation must choose between alternative ways of life". Nesse contexto, havia o modo de vida capitalista, "based upon the will of the majority, and is distinguished by free institutions, representative government, free elections, guaranties of individual liberty, freedom of speech and religion, and freedom from political oppression". Em oposição, havia o modo de vida comunista, "based upon the will of the minority forcibly imposed upon the majority. It relies upon terror and oppression, a controlled press and radio, fixed elections, and the suppression of personal freedoms".

Ao Brasil, naturalmente, essa escolha também se colocava. Por isso, esse cenário internacional de bipolaridade é uma das características da nova ordem mundial que iria contribuir para a formação da política externa (e interna) brasileira a partir do governo do general Eurico Gaspar Dutra (1946-1950).

\subsubsection{A decadência europeia}

A nova ordem mundial que emergiu a partir de 1945, caracterizada como sociedade internacional global (WATSON, 1992), teve duas faces. A primeira, como visto, foi a ascensão das duas superpotências mundiais, Estados Unidos e União Soviética. A segunda face, a seu turno, foi, justamente, a decadência das antigas potências (europeias), substituídas pelas novas superpotências (mundiais). Analisando a conjugação desses duas faces decadência das antigas potências europeias e emergência das novas superpotências mundiais -, Vaïsse (2013, p. 5) afirma que o fim da Segunda Guerra Mundial levou a uma ruptura

\footnotetext{
${ }^{9}$ Harry Truman, "Recommendation for assistance to Greece and Turkey" (12 de março de 1947).
} 
fundamental na história da humanidade no plano das relações internacionais - e. naturalmente, ao Brasil também.

Abordando-se especificamente a questão da decadência europeia, ela teve por consequências principais: a migração do centro hegemônico do poder mundial, a emergência de novos valores políticos, ideológicos e sociais, a multiplicação da quantidade de países independentes. Cada um desses fatores exigiu um posicionamento do Itamaraty, de forma que a decadência europeia no pós-1945 e suas consequências também contribuiriam para a elaboração da política externa brasileira.

A decadência europeia pode ser aferida segundo múltiplos critérios. Inicialmente, tomando-se decadência pela acepção de degradação física, pode-se testemunhar a decadência europeia por meio da destruição que a Segunda Guerra Mundial que infligiu ao continente. Nesse sentido, os dados apresentados por Pollard (1997, p. 2) são ilustrativos. Na União Soviética, 17 mil cidades e 70 mil vilas foram destruídas, tendo ocorrido o mesmo com 65 mil quilômetros de estadas de ferro e com 13 mil pontes. O estoque habitacional foi diminuído em 20\% na Alemanha e em 9\% no Reino Unido, devido aos bombardeios. Na França, das 17 mil locomotivas existentes antes da guerra, só restaram 3 mil - uma redução de 82\%. Na Polônia, $60 \%$ de toda a criação de animais foi eliminada.

Em termos demográficos, a destruição do Velho Continente também foi evidente. $\mathrm{Na}$ Segunda Guerra Mundial, ao total, foram perdidas 35 milhões de vidas europeias, o que corresponde a $70 \%$ de todas as vítimas fatais produzidas pelo conflito, estimadas em 50 milhões, segundo Frank, Girault e Thobie (1993, p. 88-89). Para Pollard (1997, p. 1), inclusive, esse número foi ainda maior, alcançando entre 40 e 45 milhões de vidas europeias.

Dados econômicos fornecem outra forma de identificar a decadência europeia. A situação do Reino Unido é bastante ilustrativa. No início do século XX, o país era o banco do mundo, detendo, junto com a França, 70\% de todos os investimentos no exterior (DÖPCKE, 2008, p. 87). Em drástico contraste, após a Segunda Guerra Mundial, o Reino Unido tornouse o grande devedor mundial. Nesse sentido, em dezembro de 1945, o governo britânico recebeu dos Estados Unidos um empréstimo de US\$ 3,75 bilhões - em valores da época. Para se ter uma magnitude do que isso significativa, essa quantia equivalia a $40 \%$ de todos os recursos planejados para o Fundo Monetário Internacional (WYATT-WALTER, 2004, p. 134). Além disso, o Reino Unido foi o maior beneficiário do Plano Marshall (oficialmente 
Programa de Recuperação Europeia), recebendo, aproximadamente, 25\% dos US\$ 13 bilhões (em valores da época) distribuídos entre 1947 e 1951 (PRENTZAS, 2011). Na lista dos maiores beneficiários do Plano Marshall, sucederam ao Reino Unido outros importantes países europeus, conforme se verifica na tabela 1.

\begin{tabular}{|c|c|c|}
\hline & Total (em milhões dólares) & $\%$ \\
\hline Reino Unido & $3.165,8$ & 24,4 \\
\hline França & $2.629,0$ & 20,3 \\
\hline Itália & $1.434,6$ & 11,0 \\
\hline República Federal da Alemanha & $1.317,3$ & 10,1 \\
\hline \multirow[t]{2}{*}{ Países Baixos } & $1.078,7$ & 8,3 \\
\hline & $12.992,5$ & 100 \\
\hline
\end{tabular}

Tabela 1. Traduzida e extraída de Vaïsse (2013, p. 19).

Outro modo de verificar a decadência econômica europeia é pela comparação diacrônica da riqueza, medida pelo PIB. Nesse sentido, em 1939, o PIB das potências europeias beligerantes, do Japão e da União Soviética correspondia ao dobro do PIB norteamericano. Em 1946, o PIB norte-americano torno-se maior que o de todas aquelas economias juntas (FRIEDEN, 2008, p. 284). Mesmo depois de cinco anos após o fim da Segunda Guerra Mundial, o declínio europeu continuou evidente, conforme se verifica comparando-se o PIB das antigas potências europeias com o da superpotência norteamericana. Assim, em 1950, o PIB britânico correspondia a 22\% do norte-americano; estando o alemão e o francês em situação ainda pior, pois correspondiam, cada um, a apenas $14 \%$ do PIB dos Estados Unidos (WYATT-WALTER, 2004, p. 139).

Esse quadro, naturalmente, contribuía para a conformação da política externa brasileira, que também foi influenciada por outros aspectos da decadência europeia. Nesse sentido, a capacidade do continente europeu de importar ficou reduzida a $1 / 3$ do que fora em 1938. A frota de navios mercantes, por sua vez, estava reduzida à metade da americana em 1947, enquanto the era o triplo em 1939. Na produção de aço, tendência similar foi verificada. Em 1946, a produção alemã, britânica e soviética, juntas, também ficou reduzida à metade dos Estados Unidos, enquanto era 15\% maior à deste país em 1939. Em termos de padrão de vida, o índice de 1946 equivalia: na Itália e no Japão, ao de 1910; na Alemanha, ao de 1890; e na Áustria, ao de 1870 (FRIEDEN, 2008, p. 283-284). 
Em decorrência do declínio do Velho Continente, os povos sob jugo colonial europeu foram ganhando independência - e a extensão do domínio colonial foi reduzindo-se. Em 1900, quase $50 \%$ de toda a superfície terrestre do planeta eram colônias, o que correspondia a aproximadamente 70 milhões de quilômetros quadrados (DÖPCKE, 2008, p. 98) sob o domínio de potências coloniais. Uma consequência imediata desse vasto território colonial era o número reduzido de países independentes. Em 1914, por exemplo, o número de Estados soberanos era 59 (FERGUSON, 2001, p. 383). Em 1946, após os dois conflitos mundiais, que tiveram significativo impacto sobre as antigas potências coloniais, esse número aumentou para 74 países independentes. Em mais 5 anos, em 1950, alcançou-se a quantidade de 89, o significa um acréscimo total de quase 50\% ante 1946 (FERGUSON, 2001, p. 383).

Esse quadro ilustra, com nitidez, o processo de decadência europeia medida pela emergência de novos países. Houve, nesse sentido, uma relação inversamente proporcional entre o poder da Europa e as independências nacionais. Assim, quanto menos poder tinha o continente europeu (ou, em outros termos, quanto mais decaia), mais países se formavam nesse vácuo de poder, relação que é demonstrada pelos dados supramencionados.

\subsubsection{A nova ordem econômica ocidental}

As duas seções anteriores analisaram, individualmente, dois movimentos de um mesmo processo. Expuseram, respectivamente, o movimento de ascensão dos Estados Unidos e o movimento de queda da Europa Ocidental. Somados, esses dois processos corresponderam à configuração ocidental da nova ordem mundial - esta, a era das superpotências, nos termos de Watson (1992). O exemplo mais eloquente dessa dinâmica foi a emergência de uma nova ordem econômica ocidental, ditada pelos Estados Unidos, sob cuja dependência ficaram as antigas potências europeias e sob cuja zona de influência se inseriu o Brasil.

\subsubsection{Analisando o adjetivo ocidental}

Antes de se abordar, propriamente, essa nova ordem econômica ocidental, passa-se a justificar o uso do qualificativo "ocidental". Fora dito anteriormente que ao fim da Segunda Guerra Mundial sucedeu a emergência da sociedade internacional global (WATSON, 1992). 
Com isso, aprofundou-se o processo de globalização - entendida, apenas, como o incremento das interconexões entre as sociedade, de modo que eventos em uma parte do mundo afetam, cada vez mais, pessoas e sociedade distantes (BAYLIS; OWENS; SMITH, 2008, p. 8).

Essa trajetória de aprofundamento da globalização poderia sugerir que, após a Segunda Guerra Mundial, o mundo se unificou. Como é sabido, não foi o que ocorreu. É necessário distinguir, então, unidade e interconexão. Dessa forma, apesar de o mundo ter-se tornado cada vez mais interconectado após 1945, sua unidade política não se verificou.

Nesse sentido, como também fora dito, a primeira manifestação da sociedade internacional global foi a era das superpotências (WATSON, 1992). Assim, entre as várias fragmentações políticas do mundo pós-1945, a principal foi a divisão bipolar entre Ocidente (Estados Unidos) e Oriente (União Soviética) que caracterizou a Guerra Fria ${ }^{10}$. Esta, por sua vez, foi uma divisão (e uma disputa) não apenas política, mas também ideológica e econômica (SARAIVA, 2008, p. 200). Desse modo, durante a Guerra Fria, sob o amparo da sociedade internacional global (WATSON, 1997), abrigaram-se duas ordens político-econômicoideológicas antagônicas: uma ocidental e outra oriental.

Embora essas três dimensões (política, ideológica e econômica) formem um conjunto orgânico indissociável na prática, elas podem, em termos analíticos, ser investigadas individualmente. É nesse sentido, então, que se fala em ordem econômica ocidental, para se referir ao regime ${ }^{11}$ econômico vigente na esfera de influência dos Estados Unidos.

A adoção da ordem econômica ocidental nesta seção é pelo fato de ter sido a ela que o Brasil se filiou - e não à oriental. Além disso, o estudo dessa ordem justifica-se, pois ela foi um dos elementos que contribuíram para a "imposição do alinhamento" à política externa brasileira no pós-1945.

\subsubsection{Analisando a nova ordem}

Analisando-a propriamente, a ordem econômica ocidental do pós-1945 começou a ser cunhada antes mesmo do fim da Segunda Guerra Mundial. Como origem remota, pode-se

\footnotetext{
${ }^{10}$ Segundo Odd Westad (2010, p. 3), o termo Guerra Fria foi cunhado pelo escritor britânico George Orwell no artigo "You and the atomic bomb", 19 de outubro de 1945. Com a expressão, Orwell retratou, de maneira negativa, o estado de guerra não declarado entre Estados Unidos e União Soviética.

${ }^{11}$ Por regime, entende-se "sets of implicit or explicit principles, norms, rules, and decision-making procedures around which actor's expectations converge in a given area of international relations" (KRASNER, 1982, p. 2).
} 
mencionar a aprovação pelos Estados Unidos da Lei dos Acordos Recíprocos de Comércio (RTAA, na sigla em inglês), em 1934. A RTAA foi uma espécie de antecessora da figura atual da Fast Track Authority (FTA), permitindo ao Executivo norte-americano a determinação das tarifas aduaneiras sem consulta ao Congresso. Isso, por sua vez, possibilitou a reversão da ultraprotecionista Tarifa Smoot-Hawley, de 1930 (IRWIN, 2008).

A RTAA não é registrada, nesta seção, pelo fato de ter permitido a expansão de mercados para as manufaturas dos Estados Unidos, país que, já em 1936, seria responsável por 32\% da produção manufatureira mundial (POLLARD, 1997, p. 3). Ela é registrada, sim, por revelar o pensamento de seu principal e mais incisivo patrocinador, o secretário de Estado Cordell Hull. Comentando sobre o espírito da RTAA, Hull informou: "to me, unhampered trade dovetailed with peace; high tariffs, trade barrier, and unfair economic competition, with war" $^{12}$. Consequentemente, ao se alcançar um fluxo mundial de comércio mais livre - com menos restrições -, "one country would not be deadly jealous of another and the living standards of all countries might rise, thereby eliminating the economic dissatisfaction that breeds war, we might have a reasonable chance for lasting peace".

Essa perspectiva é, claramente, filiada à tradição liberal clássica de que o livrecomércio é promotor da paz. Com origens remotas em Montesquieu, Kant e Bentham, no século XVIII, e em Stuart Mill e Richard Cobden, no século XIX, essa vertente teórica do liberalismo clássico defende que o livre-comércio, ao promover o desenvolvimento nacional, cria um interesse material concreto pela promoção e manutenção da paz. Paralelamente, o livre-comércio tem uma função civilizadora, ao promover contato e tolerância entre diferentes culturas (MESSARI; NOGUERIA, 2005, p. 62-63). Por um motivo ou por outro, o livrecomércio estaria em relação positiva com a paz - mais comércio, mais paz.

O endosso de Hull a essa ideia foi evidente, mesmo após a Segunda Guerra Mundial, quando o prestígio dessa perspectiva teórica ficou severamente abalado. Nesse sentido, em resposta àqueles que argumentavam os tratados de livre-comércio não haviam impedido a guerra total entre 1939 e 1945, Cordel Hull afirmou: "yes, war did come, despite trade agreements. But it is a fact that war did not break out between the United States and any country with which we had been able to negotiate a trade agreement"13. Além disso, Hull

\footnotetext{
${ }^{12}$ Hull (1948, p. 81).

${ }^{13}$ Ibidem, p. 365.
} 
ressaltou que "with very few exceptions, the countries with which we signed trade agreements joined together in resisting the Axis. The political line-up followed the economic line-up".

Verifica-se que essa crença na promoção da paz pelo comércio era profunda em Hull, que a esposava desde muito cedo, como demonstram várias passagens de suas Memórias. Mais que isso - e, talvez, por isso -, essa rationale iria guiar e pautar a atuação internacional de Cordell Hull durante aquele que foi o mais longo mandato de um secretário de Estado na história dos Estados Unidos - entre março de 1933 e novembro de 1944.

Em consequência, a longevidade de Hull na Secretaria de Estado e sua crença na função pacificadora do livre-comércio teriam, ambas, impacto significativo na conformação da ordem econômica ocidental do pós-guerra - e da política externa brasileira. Dessa forma, durante o mandato de Hull, quanto mais o caráter de superpotência mundial dos Estados Unidos se definia, mais o regime econômico do Ocidente se imbuía de liberalismo. Não à toa, essa vertente teórica seria verificada em muitos dos instrumentos que conformariam esse regime - e nos instrumentos que levariam a ele.

Em agosto de 1941, por exemplo, firmou-se a Carta do Atlântico - que, em 1942, seria incorporada à Declaração das Nações Unidas ${ }^{14}$. Emanada como uma declaração conjunta de Roosevelt e Churchill, a Carta do Atlântico continha "common principles in the national policies of their respective countries on which they base their hopes for a better future for the world". Assim, todos os seus oito princípios eram formas de se construir um mundo melhor o que, naquele momento, podia traduzir-se como alcançar a paz.

É com base nisso que se lhe interpretam o quarto e o quinto princípios como uma homenagem à crença liberal clássica de que o comércio exerce função pacificadora entre as nações. Nomeadamente, o quarto princípio prescreve que Estados Unidos e Reino Unido iriam empenhar-se "to further the enjoyment by all States, great or small, victor or vanquished, of access, on equal terms, to the trade and to the raw materials of the world which are needed for their economic prosperity"15. O quinto, a seu turno, registra o desejo

\footnotetext{
${ }^{14}$ A Declaração das Nações Unidas, de 1942, é, inclusive, uma das referências para o reconhecimento de um país como membro fundador da Organização das Nações Unidas. Nesse sentido, lê-se no artigo 3 da Carta da ONU: "os membros originais das Nações Unidas serão os Estados que, tendo participado da Conferência das Nações Unidas sobre a Organização Internacional, realizada em São Francisco, ou tendo assinado previamente a Declaração das Nações Unidas, de 1 de janeiro de 1942, assinarem a presente Carta, e a ratificarem, de acordo com o Artigo 110."

15 UNITED NATIONS (1947, p. 2). Como se está analisando a construção da ordem econômica ocidental, liberal, foram expostos, apenas, os princípios quarto e quinto. Toda a Carta, contudo, é uma defesa do liberalismo sob diversas formas, como autodeterminação dos povos, liberdade individual, democracia.
} 
daqueles dois países "to bring about the fullest collaboration between all nations in the economic field with the object of securing, for all, improved labour standards, economic adjustment and social security".

Conforme apontado por Gardner (1956, p. 49), esses princípios foram interpretados, já na época, como uma vitória dos pilares da política econômica internacional dos Estados Unidos, como o reconhece o próprio subsecretário de Estado Summer Welles. Isso demonstra a força crescente tanto dos Estados Unidos quanto do pensamento de Hull, que, assim, como Roosevelt, via a Carta do Atlântico como princípios universais (GARDNER, 1956, p. 49; SHERWOOD, 1998, p. 525). Assim, cada vez mais desde a década de 1930, o liberalismo (e, especificamente, o livre-comércio) era identificado como um imperativo a todos os Estados, sentimento que crescia inclusive no Brasil.

Outra demonstração dessa força crescente é o próprio Acordo Geral sobre Tarifas e Comércio (GATT, na sigla em inglês). Apesar de ter sido estabelecido em 1947, após o mandato de Hull à frente do Departamento de Estado, o GATT simbolizou o ápice da crença no livre-comércio. Não só isso: como apontado por Dam (2005), os princípios gerais de Cordell Hull em relação ao comércio insculpidos no RTAA, de 1934, foram a força motriz por trás do GATT. Em relação a esses princípios, Dam (2005) destaca, especialmente, o princípio da não discriminação e o princípio da cláusula incondicional de nação mais favorecida. Essa seria a base do sistema multilateral de comércio do GATT e, posteriormente, da Organização Mundial do Comércio (OMC), que eram, ambos, inspirados na ideia liberal da função pacificadora do comércio.

Para além do livre-comércio - corporificado, a partir de 1947, pelo GATT - dois outros elementos definiram a ordem econômica ocidental: a estabilidade monetária internacional e a recuperação dos investimentos internacionais. Todos os três elementos representavam esforços norte-americanos de construção da nova ordem do pós-guerra (FRIEDEN, 2008, p. 276).

Se o pilar do livre-comércio só foi institucionalizado em 1947 - mesmo que de forma provisória, sob o arcabouço do GATT -, os outros dois pilares foram erigidos ainda durante o transcurso da Segunda Guerra Mundial. Tanto a estabilidade monetária internacional quanto a recuperação dos investimentos internacionais ganharam caráter institucional pelos acordos de Bretton Woods, de julho de 1944, aprovados com o endosso brasileiro. Quanto à estabilidade 
monetária, havia menos resistência nos atores responsáveis, em comparação com a política de livre-comércio. Contra esta, emergiam muitas empresas e indústrias cujas elevadas margens de lucro dependiam de barreiras comerciais.

Em relação a um sistema monetário internacional, a oposição era praticamente inexistente. $\mathrm{O}$ que se colocava era como implementar esse sistema. Duas eram as vertentes principais. A primeira defendia o retorno integral ao padrão ouro - posição dos financistas de Wall Street, por exemplo. A segunda, por sua vez, reconhecia os méritos do padrão ouro, mas opunha-se à inflexibilidade que caracterizava esse sistema, que anulava a possibilidade de se fazer política monetária ativa. Assim, industriais e trabalhadores defendiam a retomada do padrão ouro sob novas bases (FRIEDEN, 2008, p. 279).

Em Bretton Woods, John Maynard Keynes e Harry Dexter White, representantes do Reino Unido e dos Estados Unidos, respectivamente, conciliaram essas duas vertentes, ao instituírem o Fundo Monetário Internacional. (FMI). Por meio dessa instituição, obtinham-se estabilidade monetária, flexibilidade e referência ao padrão ouro sem rigidez (FRIEDEN, 2008, p. 280). Fundava-se, então, o padrão ouro-dólar, que seria referência para o mundo ocidental - e, naturalmente, o Brasil - até 1971, quando o presidente Richard Nixon, unilateralmente, pôs fim à conversibilidade do dólar ao ouro.

Pelo sistema do FMI, os 45 países fundadores fixariam o valor de referência de paridade entre suas moedas e o ouro. Com isso, objetivavam-se a estabilidade cambial, a livre circulação das divisas e a conversibilidade entre as moedas (ALMEIDA, 1996, p. 178). Para evitar que a liberdade de divisas causasse crises profundas na balança de pagamentos dos países e que essas crises nacionais se convertessem em crises sistêmicas, o FMI também teria a função de estabilizador do sistema monetário internacional. Especificamente, concederia créditos de curto prazo para reverter crises no balanço de pagamento nacional.

Em relação aos investimentos internacionais, a solução para a recuperação desses também foi encontrada em Bretton Woods. Tratou-se da criação do Banco Internacional para a Reconstrução e o Desenvolvimento - o Banco Mundial. Como o próprio nome sugere, seu objetivo era financiar a reconstrução dos países devastados pela guerra, bem como promover o progresso econômico dos países menos desenvolvidos (ALMEIDA, 1996, p. 178). Essa necessidade era posta à medida que o fim da Segunda Guerra Mundial se tornava mais claro no horizonte. Essa necessidade, no entanto, defrontava-se com a relutância dos credores em 
financiar grandes projetos, cujo tempo de maturação era tão extenso que estes eram evitados pelos investidores privados (FRIEDEN, 2008, p. 280-281).

A solução a esse impasse foi encontrada pela fundação do Banco Mundial. Por meio dele, obtinham-se empréstimos a juros baixos junto à iniciativa privada, que se disponha a oferecê-los devido às garantias ofertadas pelos governos fundadores do banco. Em posse desses recursos, o Banco Mundial repassava-os a projetos de longo prazo que apresentassem margens de lucro significativas e que facilitassem outros investimentos privados (FRIEDEN, 2008, p. 281). Assim, o Banco Mundial, com capital inicial de US\$ 10 bilhões, era, em essência, um intermediador financeiro entre países receptores de empréstimo e fornecedores privados de capitais (POLLARD, 1997, p. 80).

Naturalmente, a reconstrução dos países europeus devastados pela guerra ganhou mais atenção nos anos iniciais do Banco Mundial. Com o transcorrer do tempo, à medida que esses países se reerguiam, ganhou mais evidência a função de promoção de desenvolvimento econômico dos países de renda média. Nesse sentido, a partir de 1970, esse segundo grupo de países passou a ser beneficiário de mais de $90 \%$ dos empréstimos concedidos pelo Banco Mundial (POLLARD, 1997, p. 81).

Para o Ocidente, esse sistema tripartite - livre-comércio, estabilidade monetária internacional, investimentos internacionais - teve dois significados inter-relacionados. $\mathrm{O}$ primeiro foi a comprovação do ocaso das antigas potências europeias da póstuma sociedade internacional europeia (WATSON, 1992), que davam vez à superpotência mundial ocidental da nascente sociedade internacional global (WATSON, 1992).

Assim, as instituições que emergiram no período e que regulariam a ordem econômica ocidental doravante foram, essencialmente, propostas norte-americanas (POLLARD, 1997. p. 77) - o que sugere a força do alinhamento que se imporia sobre o Brasil no pós-1945. Inclusive, essa manifestação do poder estadunidense era sentida pelos negociadores em Bretton Woods. O próprio Keynes assistia, ressentido, à transformação de seu projeto econômico em instrumento político do poder norte-americano (FRIEDEN, 2008, p. 282).

O segundo significado foi a institucionalização, a nível mundial, do liberalismo norteamericano (VIANNA, 2014, p. 105). Assim, a ordem econômica dos 25 anos posteriores à Segunda Guerra Mundial (FRIEDEN, 2008, p. 283) foi instituída sob dois pilares: os objetivos de desenvolvimento e as convicções da política econômica dos Estados Unidos. 
Para o Brasil, o sistema econômico que se elaborava a partir de Bretton Woods teve impacto significativo. O país, como membro do mundo ocidental, encontrava-se inserido na área de vigência desse sistema. Assim, estava submetido aos aspectos procedimentalinstitucional (GATT, FMI, Banco Mundial) e ideológico (liberalismo) dessa nova ordem econômica ocidental. Prova do primeiro aspecto é manifestada pela participação do Brasil em Bretton Woods, onde esteve, por exemplo, o ministro da Fazenda de Vargas, Artur de Souza Costa. Este, inclusive, presidiu um dos comitês da comissão relativa à fundação do FMI (ALMEIDA, 1996, p. 177).

O segundo aspecto, o ideológico, iria ser mais um elemento a desestabilizar o governo Vargas. Conforme será demonstrado nas seções seguintes, o liberalismo econômico serviu de referência tanto para a oposição ao intervencionismo econômico de Vargas quanto para a fundação de uma nova ordem econômica nacional no período posterior a 1945.

É nesse contexto que o governo seguinte ao de Vargas teve sua política econômica inicial fundamentada na "ideia de um mundo organizado de acordo com os princípios liberais de Bretton Woods" (VIANNA, 2014, p. 105). Afirmava-se, então, a força tanto do liberalismo quanto dos Estados Unidos na política brasileira.

\subsubsection{Balanço da nova arena internacional}

O estudo das transformações no cenário internacional é indispensável para se compreender a ordem - nacional ou internacional - que nasceu a partir de 1945. A decadência europeia, a ascensão norte-americana (especificamente para o Ocidente) e a bipolaridade (com a ascensão da União Soviética) delimitaram a arena internacional na qual os países tiveram de atuar após a Segunda Guerra Mundial.

No tocante às relações internacionais do período, a compreensão dessas transformações profundas é imprescindível para, por exemplo, assimilar-se a força (prática e retórica) do princípio da autodeterminação dos povos, em resposta à decadência das antigas potências coloniais europeias. Nesse sentido, seguiu-se um forte sentimento anticolonialista que, em alguns casos, se confundia com uma oposição ao Ocidente (BRADLEY, 2010) - a exercer pressão sobre a política externa dos países, inclusive do Brasil. 
Igualmente, essas transformações ajudam a explicar o ambiente de rivalidade ideológica que impunha a necessidade da filiação a um dos lados. Auxiliam, da mesma forma, a demonstrar os fundamentos que determinariam a constituição da Organização das Nações Unidas, que se defrontava com a missão de conciliar dois objetivos contraditórios. Por um lado, devia estabelecer um sistema internacional que preservasse "as gerações vindouras do flagelo da guerra, que, por duas vezes, no espaço da nossa vida, trouxe sofrimentos indizíveis à humanidade"16. Por outro lado, era-lhe cobrado que incorporasse nesse novo sistema internacional "o grande cisma"17 trazido pela Guerra Fria, que se delineava e que gerava disputas de poder com a ameaça constante de uma nova - e última - guerra mundial.

Em relação ao contexto específico do Brasil, essas transformações no cenário internacional delimitaram a arena para a qual teve de ser formulada a política externa brasileira no pós-Segunda Guerra Mundial. Elas ajudam a compreender, por exemplo, como os Estados Unidos chegaram a ter participação média de 49,59\% no comércio externo brasileiro, entre 1946 e $1950^{18}$ - o que, naturalmente, exercia grande influência sobre a conformação das opções políticas do Brasil.

Igualmente, contribuem para justificar a adoção pelo Brasil do liberalismo - tanto na política interna quanto na política externa. Assim, ganha-se mais densidade o argumento de que essa adoção não foi um ato gratuito de liberalidade, mas uma imposição do período.

Nesse sentido, entender que, a partir de 1945, o sistema internacional passava por transformações profundas é a primeira etapa para se compreender a atuação internacional brasileira no período. Outra etapa igualmente relevante é entender que o próprio Brasil também passava por transformações, ao que se passa a dedicar-se.

\subsection{O Brasil de 1945: a dicotomia entre Estado e governo ${ }^{19}$}

\footnotetext{
${ }^{16}$ Preâmbulo da Carta da ONU.

${ }^{17}$ Referência ao título do livro de Raymond Aron (1948).

${ }^{18}$ Valor obtido a partir do cruzamento entre dados disponíveis no site IPEADATA (http://ipeadata.gov.br) e em material do IBGE (1987).

${ }^{19}$ É lícito adotar essa divisão analítica, já que Estado e governo são entidades distintas. Inclusive, o primeiro critério adotado por Roberton (2004, p. 357) para definir Estado é sua diferença em relação a governo. A entidade Estado refere-se ao arcabouço jurídico-político-institucional, que é estável e (em teoria) neutro. Nele, operam os sucessivos governos, que são transitórios e vinculados a partidos políticos. Aplicando esses conceitos ao contexto brasileiro de 1945: o governo Vargas atuava no Estado da República dos Estados Unidos do Brasil.
} 
As alterações ocorridas no âmbito mundial são uma parte da explicação para a emergência de uma nova ordem também no Brasil - o que, naturalmente, implicava a emergência de uma nova política externa -, conforme se demonstra nesta seção. A metade restante da explicação é fornecida pelo desgaste do longo governo getulista, bem com pela crescente oposição a esse regime, o que será analisado na seção seguinte. A interação entre esses dois fatores desencadeou um processo que levou à deposição de Getúlio Vargas e, posteriormente, à eleição, em 1945, do ex-ministro da Guerra Eurico Gaspar Dutra para presidente. Para a política externa, esses fatos contribuíram para o bloqueio de outras opções de inserção internacional, o que se caracteriza como "imposição do alinhamento".

Em 1945, as consequências da Segunda Guerra Mundial impactaram o Brasil de maneira imediata. Isso deveu-se, notadamente, à lógica complexa por meio da qual interagiam as esferas políticas doméstica e externa. Por um lado, o país compunha o grupo vencedor, de forma que o Estado brasileiro (República dos Estados Unidos do Brasil) se encontrava na vanguarda da história, posicionado junto às nações vitoriosas no conflito bélico-ideológico da Segunda Guerra Mundial. Por outro lado, o governo brasileiro (Vargas) estava intimamente associado ao lado derrotado, uma vez que vigorava um governo autoritário ou de exceção desde 1930 - ou, pelo menos, desde 1937. Desse modo, o resultado da Segunda Guerra Mundial lançou o Brasil em uma contradição profunda entre Estado (vencedor, forças liberais) e governo (vencido, forças autoritárias).

A dicotomia entre Estado e governo era percebida e capitalizada tanto por tradicionais opositores ao regime em curso quanto por getulistas dissidentes. Exemplo destes, José Américo de Almeida, ex-ministro de Viação e Obras Públicas entre 1930 e 1934, declarou ao Correio da Manhã em 22 de fevereiro de 1945 "embora não queiramos sofrer influências estranhas, evidentemente o Brasil tem de receber os reflexos da guerra, do caráter ideológico da guerra, que é uma luta pela sobrevivência e purificação da democracia"20, de tal forma que "a vitória que os nossos compatriotas da FEB foram buscar na Europa é uma vitória atual para a nossa geração, sim, mas sobretudo uma vitoria para o futuro do Brasil".

Esse diagnóstico era ecoado mesmo entre as fileiras do getulismo, do que Francisco Campos foi um irônico e notório exemplo. Irônico, porque ele havia sido o responsável pela legitimação jurídica da ditadura estadonovista, tendo escrito a Constituição de 1937. Irônico

\footnotetext{
${ }^{20}$ Correio da Manhã, edição de 22 de fevereiro de 1945, p. 1.
} 
também pelo fato de ter sido Ministro da Educação e Saúde ${ }^{21}$ e, posteriormente, Ministro da Justiça (FERNANDES, 2007). Notório, pois o jurista e político descreveu, de maneira bastante clara e direta, o dilema do Brasil de 1945, caracterizado, nesta seção, como dicotomia entre Estado e governo. Em entrevista concedida ao Correio da Manhã em 3 de março de 1945, registrou: "não podemos, vitoriosos na guerra, deixar que subsistam motivos para sermos colocados, do ponto de vista ideológico, no campo dos vencidos. Atualizemos as nossas instituições políticas"22. No mundo que emergia ao se delinear o fim da Segunda Guerra Mundial, "não podemos ter o lugar que hoje nos compete se não comparecermos com trajes que obedeçam aos padrões da propriedade e da decência, estabelecidos pelo comum acordo das nações vitoriosas".

Outros responsáveis pela viabilização inicial do Estado Novo também partilhavam do mesmo diagnóstico. Até no próprio aparato militar, essa opinião era encontrada. Disso são exemplos apontados por Hilton (1987) os generais Renato Paquet, comandante da Vila Militar do Rio de Janeiro; Ângelo de Morais, chefe da diretoria de pessoal do Exército (Diretoria de Armas); Mário Ary Pires, comandante do Quinta Região Militar; Cristovão Barcelos, Chefe do Estado-Maior do Exército; Góes Monteiro, ex-Chefe do Estado Maior (1937-1944) e então representante brasileiro junto ao Comitê de Emergência e Defesa Política da América.

Outro exemplo notório foi o então Ministro da Guerra Eurico Gaspar Dutra. Ele, conforme indica Hilton (1987, p. 11), em 23 de outubro de 1945, ao retornar de uma visita à FEB, ressaltou a Vargas "the incongruity between Brazil's international and national situations, i.e., the fact that the country was an active partner in the Allied coalitions doing battle against fascism in Europe while being governed itself by a dictatorship".

Em consequência de seu diagnóstico, o general Dutra recomendava que Vargas convocasse eleições antes mesmo do fim da guerra. Assim, lê-se em carta secreta enviada a Getúlio Vargas em 27 de dezembro de 1944: "julgo perfeitamente aceitável o alvitre de se promoverem as eleições e a normalização constitucional ainda antes que a guerra termine"23, o que iria permitir "em melhores condições a consulta eleitoral ao povo, pois longe de nossas

\footnotetext{
${ }^{21}$ Francisco Campos, inclusive, foi o primeiro ministro do então recente "Ministério dos Negócios da Educação e Saúde Pública" (FERNANDES, 2007), ministério criado pelo decreto federal nº 19.402, de 14 de novembro de 1930, pouco mais de um mês após a Revolução de 1930.

${ }^{22}$ Correio da Manhã, edição de 03 de março de 1945, p. 1.

${ }^{23}$ CPDOC, GV c 1944.12.27.
} 
fronteiras resta a guerra, e em plena tranquilidade o país, não mais ocorrendo no presente os ponderosos motivos que inspiraram o adiamento dela em 1942".

Esses testemunhos, ao vocalizarem a dicotomia entre Estado e governo, denunciavam e intensificavam a fragilidade da administração Vargas. Dessa forma, verifica-se que a complexa dinâmica de inserção internacional do país em 1945 foi um elemento catalizador para a deslegitimação de Getúlio. Como se demonstrou, elemento fulcral dessa desestabilização era a defesa do liberalismo - posto em oposição ao regime autoritário do Estado Novo. Assim, a "imposição do alinhamento" era gestada, ao que também contribuiu a própria dinâmica interna de desgate generalizado do governo, conforme se passa a analisar.

\subsection{A insustentabilidade política do governo Vargas}

Para se compreender como se deu a "imposição do alinhamento" na política externa, é necessário assimilar a justificativa de política interna que fundamentou a eleição de Dutra para presidente em 1945. Afinal, é em resposta a essa justificativa que serão formuladas as políticas externa e interna desse governo. Nesse sentido, argumenta-se que a República Liberal-Conservadora nasceu tendo um referencial muito claro: a oposição ao autoritarismo do regime varguista, contraposto ao liberalismo.

É bem verdade que o partido vencedor nas eleições de 1945, o PSD, fora formado a partir de quadros da máquina administrativa do Estado Novo (FAUSTO, 2009, p. 385), como o próprio Dutra. Isso leva Fausto (2013, p. 106) a afirmar que o PSD foi uma vertente do getulismo, juntamente com o PTB. Entende-se essa afirmação como, essencialmente, uma referência à origem - de onde provieram essas pessoas. A consequência desse entendimento é que o fato de haver antigos integrantes do governo Vargas no governo Dutra não invalida o argumento de que a República Liberal-Conservadora nasceu por meio da oposição ao autoritarismo do regime varguista.

Três fatos principais amparam esse entendimento. Primeiro, se o PSD fosse uma mera continuidade do governo Vargas, seus líderes não teriam promovido a derrubada deste e, principalmente, não teriam posto fim ao Estado Novo. Afinal, não haveria sentido alterar a estrutura jurídico-institucional brasileira de maneira tão drástica se o objetivo fosse continuar o governo anterior. Segundo, o apoio de Vargas à candidatura de Dutra só foi oferecido na 
última hora e "sem o menor entusiasmo" (FAUSTO, 2013, p. 106), algo que destoa da ideia de continuísmo rigoroso. Terceiro, a formação de uma coalizão nacional entre PSD e UND (uma frente ampla assumidamente liberal e antigetulista) após as eleições presidenciais de 1945 indica a existência de algum grau de comunhão política entre esses partidos - no caso, a oposição àquele autoritarismo.

Esses fatos, a despeito da ressalva de que muitos dos quadros do vitorioso PSD tenham servido ao governo Vargas, permitem defender o argumento de que a República Liberal-Conservadora nasceu pela a oposição ao autoritarismo do regime varguista. A importância desse argumento é que a ele está associado outro ainda mais relevante: a oposição ao autoritarismo varguista tinha por fundamento retórico-ideacional o liberalismo.

A partir dessa referência, iniciou-se, no plano interno, a "imposição do alinhamento" à política externa brasileira do pós-1945 - no plano externo, como visto, a referência foi "a onda de liberalismo que acompanhava o fim da guerra e a consolidação da hegemonia norteamericana no Ocidente" (MENDONÇA, 2000, p. 342). Verifica-se, então, que a "imposição do alinhamento" está intimamente relacionada ao processo crescente de oposição ao regime varguista. Por essa razão, é a esse processo de oposição que se passa a dedicar-se.

\subsubsection{Autonomia da política em relação à economia}

A deterioração da base de sustentação político-social do governo Vargas intensificouse, significativamente, à medida que ficava clara a proximidade do fim da Segunda Guerra Mundial (e a vitória dos Aliados). Inclusive, nessa espiral de perda de sustentação, a esfera político-social revelou-se autônoma perante a esfera econômica, demonstrando que não há relação direta necessária entre governabilidade e economia ${ }^{24}$.

Às vésperas da deposição de Vargas, em 1945, o cenário econômico que se colocava eram anos sucessivos de saldos comerciais e crescimento da indústria e do PIB. A partir de 1941-1942, a balança comercial apresentou expressivos saldos positivos, resultantes, essencialmente, da combinação de três fatores. O primeiro foi a escassez das importações posta pelo contexto do conflito mundial. O segundo foi o aumento das exportações, oriundo de acordos de suprimento de materiais estratégicos para os Estados Unidos, maciças compras

\footnotetext{
${ }^{24}$ No caso, entende-se por relação direta: se a economia prospera, o grau de governabilidade é alto; se há crise econômica, a governabilidade se deteriora.
} 
de carne e algodão pelo Reino Unido. O terceiro foi a melhora dos preços do café, resultante do Acordo Interamericano. Em termos de produto industrial, houve crescimento de 1,6\% entre 1940 e 1942; e de 9,8\%, entre 1943 e 1945. Quanto ao PIB, houve crescimento de 0,3\% entre 1940 e 1942; e de 6,4\% entre 1943 e 1945, não sendo ainda mais alto por causa do baixo desempenho do produto agrícola (ABREU, 2014, p. 95-96).

Esses dados demonstram que a Segunda Guerra Mundial trouxe ganhos econômicos para o Brasil, especialmente a partir de 1942. Isso, contudo, não impediu que, ao fim do referido conflito, se desencadeasse uma escalada oposicionista contra Getúlio, levada a cabo até mesmo pelos setores que haviam prosperado economicamente ao longo desse governo.

A Carta econômica de Teresópolis, de maio 1945, ilustra essa cisão entre o regime varguista e as classes produtivas (que tiveram ganhos econômicos nesse período). Esse documento foi o produto final da I Conferência Nacional das Classes Produtoras, promovida pela Federação das Associações Comerciais do Brasil e da Confederação Nacional da Indústria. Assim, sintetizava o diagnóstico político-econômico das principais entidades produtivas do país. Seu contexto é descrito no próprio preâmbulo: "no momento em que, num clima de profundas transformações mundiais de ordem econômica, social e política, o Brasil se prepara para reestruturar suas instituições de governo"25. Assim, verifica-se a percepção pelas "classes produtoras" de que o país - e o mundo - se encontrava em um momento fundador de sua história.

Esse caráter originário de "reestruturação das instituições" brasileiras passava pelo que, na Carta, se traduzia na defesa tanto da "democracia política" quanto da "democracia econômica" (SARETTA, 1995). Nos termos da Carta, tem-se: "à democracia política, que é a vocação dos brasileiros, deve corresponder uma verdadeira democracia econômica" 26 . Com isso, pode-se depreender que uma das principais características a conduzir essa nova etapa na história do país seria a maior abertura - tanto da sociedade quanto da economia.

Em termos político-ideológicos, essa maior abertura significava mais liberalismo. Defendia-se, assim, maior protagonismo para o sujeito privado - seja o indivíduo, sejam as empresas. Não à toa, o primeiro princípio quanto à ordem econômica brasileira era o de que

${ }^{25}$ CONFERÊNCIA DAS CLASSES PRODUTORAS DO BRASIL. Carta econômica de Teresópolis. Rio de Janeiro: Mauá, 1945.

${ }^{26}$ Ibidem . 
esta "se funda no princípio da liberdade e no primado da iniciativa privada"27. Constata-se, dessa forma, clara manifestação em prol de uma nova e mais aberta ordem políticoeconômica.

Paralelamente ao aumento do protagonismo do sujeito privado, advogava-se a redução da atuação estatal, que, na Era Vargas, havia sido extremamente alargada, alcançando níveis sem precedentes na República. Isso, de forma nenhuma, correspondia à defesa estrita de um Estado mínimo - ou de um liberalismo clássico. Foi o que informou a própria Carta, "esse pensamento não exclue a admissão de um certo grau de interferência do Estado, imposto por necessidade comprovada em certos casos limitados, prudentemente contida"28. Para além de casos extraordinários de segurança, essa interferência estatal seria admitida, essencialmente, para se criarem melhores condições ao desenvolvimento das atividades privadas.

Apesar desses preceitos, que eram uma manifesta oposição aos fundamentos políticoeconômicos do Estado Novo, não se pode ignorar que, nesse período e na própria Conferência de Teresópolis, ainda havia líderes industriais defendendo o governo Vargas. Dois exemplos significativos desse grupo "corporativista-nacionalista" foram Roberto Simonsen e Euvaldo Lodi. Esse grupo e seu projeto, todavia, tendo atingindo o auge entre 1943 e 1944, encontravam-se em relativo declínio quando se aproximava o fim da Segunda Guerra Mundial. Conforme demonstrado pela Carta de Teresópolis, o projeto que ganhava força era o liberal (em diversos matizes), capitaneado por expoentes como Eugênio Gudin e Otávio de Gouveia Bulhões (GUDIN; SIMONSEN; 2010).

\subsubsection{Opinião pública e sociedade civil organizada}

Para além do âmbito das forças produtivas, no âmbito da opinião pública em geral, a dissolução do apoio ao regime varguista foi evidente. Assim apontam diversas manifestações da sociedade civil organizada contrárias aos pilares político-institucionais do Estado Novo e, em sentido contrário, favoráveis a orientações liberais.

Nesse sentido, a posição da Igreja Católica apresentou uma trajetória bastante representativa da ascensão e da queda do prestígio de Vargas. Se havia reticências católicas

${ }^{27}$ CONFERÊNCIA DAS CLASSES PRODUTORAS DO BRASIL. Carta econômica de Teresópolis. Rio de Janeiro: Mauá, 1945.

${ }^{28}$ Ibidem. 
quanto à Revolução de 1930, logo a hierarquia da Igreja se deu conta das vantagens que poderiam advir da aceitação do novo regime. Vargas, igualmente, também logo compreendeu os benefícios que seguiriam à aproximação com a Igreja, por seu caráter de defensora da ordem e por seu potencial de atrair mais adeptos ao novo regime (FAUSTO, 2013, p. 94).

Dois fatos sinalizaram e efetivaram essa aproximação já no início da Era Vargas. O primeiro foi o Decreto $\mathrm{n}^{\circ} 19.941$, de abril de 1931, que facultou "nos ensinos de instrução primária, secundária e normal, o ensino da religião", cujos professores seriam "designados pelas autoridades do culto"29. A possibilidade do ensino religioso era uma clara demonstração de apoio à Igreja. Afinal, desde 1891, com a vigência da primeira Constituição republicana, tinha de ser "leigo o ensino ministrado nos estabelecimentos públicos" ${ }^{30}$, medida tomada em meio a várias outras de laicização do Estado. Posteriormente, após o Decreto de 1931, essa possibilidade de ensino religioso foi alçada à condição de garantia constitucional, quando se converteu no artigo 153 da Constituição de 1934. Para além do novo status jurídico, isso demonstrou a continuidade da parceria Vargas-Igreja Católica.

O segundo fato foi a grande festa de inauguração do monumento ao Cristo Redentor (FAUSTO, 2013, p. 94). Localizada no morro do Corcovado, no Rio de Janeiro, sua inauguração ocorreu em 12 de outubro de 1931, nove anos após o início de sua construção, em 1922. O tamanho da festividade foi apreendido, por exemplo, por reportagem d'O Globo: "assumiu grande imponência a solenidade de bênção do monumento a Cristo Redentor [...]. O ato teve a presença do chefe da Nação, dos altos dignatários da Igreja, tendo à frente o cardeal [Leme], dos ministros e representantes do mundo [...]. A montanha está apinhada" 31 .

Na cerimônia, o cardeal Sebastião Leme foi direto: o "Cristo reina, impera e livrará o Brasil de todos os males" 32 . Nesse momento, uma grande dificuldade para a Igreja era a ainda distância com o Estado, apesar de iniciativas como a troca de visitas recíprocas entre o cardeal Leme e o presidente Vargas, em janeiro de 1931, e a autorização, em abril de 1931, do ensino religioso em escolas públicas. Não à toa, o cardeal Sebastião Leme afirmou em seu discurso no dia da inauguração:

\footnotetext{
${ }^{29}$ Passagens extraídas, respectivamente, dos artigos $1^{\circ}$ e $6^{\circ}$ do Decreto ${ }^{\circ} 19.941$, de 30 de abril de 1931.

${ }^{30}$ Artigo 72, $\S 6^{\circ}$, Constituição da República dos Estados Unidos do Brasil de 1891.

${ }^{31}$ O Globo, edição de 12 de outubro de 1931, p. 1.

${ }^{32}$ Ibidem.
} 
O nome de Deus está cristalizado na alma do povo brasileiro. Ou o Estado reconhece o Deus do povo, ou o povo não reconhecerá o Estado. [...] A religião é uma das maiores forças, para não dizer a única, que pode manter intactas a integridade e a coesão do Brasil. Se os dirigentes teimarem em prescindir dos valores espirituais, eu prevejo que as competições partidárias, de regionalismo, de classes, grupos e pessoas, a falta de sinceridade, as desconfianças e ressentimentos, as vinganças e revides acabarão por estraçalhar a unidade do Brasil ${ }^{33}$.

A pressão da Igreja sobre o Estado varguista teve resultados. Firmou-se, então, um pacto entre a Igreja Católica e o Estado. Por meio desse acordo, a Igreja se comprometia com a defesa da ordem e do poder constituído, enquanto o Estado lhe garantia uma posição privilegiada no país (AZZI, 1978, p. 78).

Esse pacto, contudo, começou a ser rompido a partir de 1942, quando faleceu seu principal defensor pela Igreja, o cardeal Sebastião Leme (KORNIS, 1984). Nesse sentido, embora adotasse uma política de neutralidade eleitoral, no Rio de Janeiro, a Liga Eleitoral Católica fez campanha aberta à candidatura do udenista Eduardo Gomes (DEVOTO; FAUSTO, 2004, p. 288).

Além disso, após a queda de Vargas, diversos integrantes do Centro Dom Vital organização católica de estudos político-sociais - ingressaram na Campanha de Resistência Democrática, na União Democrática Nacional ou no Partido Democrata Cristão (KORNIS, 1984), agremiações políticas franco-opositoras ao autoritarismo varguista. Essas medidas, certamente, estavam em desacordo com a suposta "neutralidade eleitoral", na qual cria o governo, que via a Igreja "sem se definir por nenhum dos dois grandes partidos nacionais" 34 . Dessa forma, vê-se que a Igreja Católica alimentava a oposição ao governo Vargas e o "clamor liberal" que se colocaria sobre o governo Dutra.

O movimento estudantil é igualmente ilustrativo, uma vez que foi ator combativo do regime varguista - e, com igual intensidade, ecoou o "clamor liberal". Isso é exemplificado, entre outras formas, pela a atuação das Faculdades de Direito em São Paulo, no Rio de Janeiro e em Recife; bem como pela atividade da própria União Nacional dos Estudantes.

Na Faculdade de Direito de São Paulo, especificamente, o diretório acadêmico XI de Agosto era uma voz ativa no combate ao Estado Novo. Ilustrativamente, em novembro de

\footnotetext{
${ }^{33}$ Leme (apud AZZI, 1978, p. 64-65).

${ }^{34}$ CPDOC, GV c 1945.09.00/1.
} 
1943, o presidente do Diretório, Hélio Mota, discursou com "morra Getúlio! Viva a democracia" (CARONE, 1977, p. 107). Outra iniciativa do XI de Agosto, já em abril de 1944, foi o lançamento do periódico clandestino chamado Resistência. No Programa dessa revista, constava: "queremos um Brasil democrático que possa ombrear-se com as demais nações que constituem a coligação democrática e que possa apresentar-se sem opróbrio no mundo de após guerra", conforme registra Carone (1977).

A sociedade civil Amigos da América, por sua vez, é ainda mais eloquente em ilustrar a oposição crescente ao regime varguista - e o "clamor liberal". Afinal, dela participavam membros oriundos de diversos segmentos da sociedade civil com influência significativa sobre a política nacional, como engenheiros, militares, professores, médicos, jornalistas, advogados, funcionários públicos ${ }^{35}$. Essa diversidade demonstra a amplitude da frente que se insurgia a favor da implantação da democracia no Brasil. Sua amplitude foi ainda maior ao se considerar o apoio indireto - fornecido por entidades e pessoas outras que não os associados. É o caso, por exemplo, da própria UNE, cujo presidente, Hélio de Almeida, se pronunciou da seguinte forma em entrevista ao Jornal do Brasil: "com a fundação da Sociedade Amigos da América, o Brasil ganhou uma de suas melhores e mais eficientes armas [...] para a vitória completa sobre os escravizadores totalitários" 36 .

Ressalva-se que a Sociedade Amigos da América foi fundada, em novembro de $1942^{37}$, visando ao estímulo da participação brasileira na Segunda Guerra Mundial, no bloco aliado. Literalmente, conforme se lê no artigo $4^{\circ}$ da ata de registro, seu objetivo era: "congregar [...] todos os que desejarem prestar apoio efetivo [...] aos países americanos, envolvidos na conflagração mundial, imposta pelos países Totalitários, e que põe em risco a independência e liberdade dos seus povos".

\footnotetext{
35 A diversidade social dessa organização pode ser constatada a partir da análise da profissão dos 30 fundadores. Apesar da predominância de militares (11), havia engenheiros (4), médicos (4), advogados (3), professores (2), funcionários públicos (2) e dentista (1). Havia, também, três pessoas sem profissão definida, que correspondiam às mulheres presentes na lista de fundadores. Considerando que a sociedade foi fundada em 1942, a participação de mulheres não deixa de ser, por si, outro indicador de diversidade (dados compilados a partir da ata de registro oficial da Sociedade Amigos da América, publicada no Diário Oficial da União de 28 de novembro de 1942, seção 1, p. 45-46; para lista completa dos nomes e das respectivas profissões, consultar Anexo 02).

36 Jornal do Brasil, edição de 29 de dezembro de 1942, p. 6.

${ }^{37}$ Em relação à data precisa de fundação da sociedade, diferentes dias podem ser encontrados, a depender do critério utilizado. Nesse sentido, a sociedade foi autorizada a funcionar pelo Ministro da Justiça e Negócios Interiores em 4 de novembro de 1942. Essa autorização foi publicada no Diário Oficial, em 9 de novembro de 1942. A ata de registro oficial, por sua vez, foi publicada em 28 de novembro de 1942.
} 
Esse objetivo declarado de luta contra os regimes totalitários no exterior, no entanto, foi internalizando-se, de maneira cada vez mais forte, sob a forma de defesa da redemocratização do Brasil. Dada essa oposição ao regime autoritário, em 11 de agosto de 1944, no contexto de posse de sua primeira diretoria, a Sociedade Amigos da América foi fechada, e alguns de seus associados foram presos.

O fechamento da Sociedade Amigos da América, inclusive, acentuou a divergência entre Getúlio Vargas e Oswaldo Aranha. Este, que iria assumir a vice-presidência da agremiação, anunciou sua exoneração do cargo de Ministro das Relações Exteriores na esteira desse fechamento. Roberto Carneiro Mendonça, outro membro da sociedade, também se exonerou de seu cargo, Diretor da Carteira de Redescontos do Banco do Brasil. Como justificativa, informou: "não pretendo e nem desejo discutir o ato governamental. Mas não posso deixar de considerar como existente uma situação de fato, na qual, por uma questão moral, de foro íntimo, eu não me considero com o direito de permanecer"38.

Outro exemplo de sociedade civil organizada que incorporava o "clamor liberal" em favor da redemocratização do país (ou, em outros termos, em oposição aos fundamentos do Estado Novo) foi a Associação Brasileira de Escritores (ABDE) ${ }^{39}$. No I Congresso Nacional de Escritores, realizado em janeiro de 1945, no Teatro Municipal de São Paulo, a ABDE emitiu sua Declaração de Princípios, registrando que:

Os escritores brasileiros, conscientes de sua responsabilidade na interpretação e defesa das aspirações do povo brasileiro, e considerando necessária uma definição do seu pensamento e de sua atitude em relação às questões políticas básicas do Brasil, neste momento histórico, declaram e adotam os seguintes princípios:

Primeiro - A legalidade democrática como garantia da completa liberdade de expressão do pensamento, da liberdade de culto, da segurança contra o temor da violência e do direito a uma existência digna. Segundo - O sistema de governo eleito pelo povo mediante sufrágio universal, direto e secreto ${ }^{40}$.

Esses exemplos testemunham o processo de contestação ao Estado Novo - e de gestação do "clamor liberal" que seria legado ao governo seguinte. Ressalva-se, contudo, que,

\footnotetext{
${ }^{38}$ CPDOC, GV c 1944.08.17.

${ }^{39}$ A ABDE nasceu da fundação da Sociedade dos Escritores Brasileiros, em março de 1942, em São Paulo. Sua primeira diretoria foi eleita em 1943, cujos integrantes atestam a influência intelectual da entidade: Otávio Tarquínio, Carlos Drummond de Andrade, Álvaro Lins, Dante Costa, Marques Rebelo, Manuel Bandeira, Rodrigo Melo Franco de Andrade, José Lins do Rego, Astrojildo Pereira e Dinah Silveira de Queiroz (LUCA, 2008, p. 101-102).
}

${ }^{40}$ ASSOCIAÇÃO BRASILEIRA DE ESCRITORES apud LUCA, 2008, p. 106. 
em paralelo aos grupos de oposição, também havia grupos de apoio ao governo Vargas. Nesses, destacavam-se os trabalhadores urbanos. Em relação a eles, Schwarcz e Starling (2015, p 390) citam o episódio em que acadêmicos do XI de Agosto manifestavam contra o Estado Novo na Praça da Sé, mas foram interrompidos e expulsos por uma multidão que gritava "Viva Getúlio", "Nós queremos Getúlio", "Viva os trabalhadores".

A despeito do grupo "queremista", que defendia a permanência de Getúlio, o regime varguista ruiu rapidamente, em 1945. Assim, antes mesmo de acabar a guerra, Vargas convocou eleições para Presidente e para Assembleia Constituinte. O registro temporal "antes de acabar a guerra" é importante, pois Vargas havia manifestado, em diversas ocasiões e a diversos interlocutores ${ }^{41}$, que convocaria novas eleições após o término da Segunda Guerra Mundial. A antecipação do calendário é ilustrativa para demonstrar a força que havia atingido o "clamor liberal" e o movimento pela dissolução do Estado Novo.

\subsubsection{Os passos finais da transição}

O instrumento que determinou o início da abertura do regime foi a Lei Constitucional ${ }^{42} \mathrm{n}^{\circ} 9$, de 28 de fevereiro de 1945. Ela reintroduziu o voto direto, considerando que "o processo indireto [...] priva [o Presidente da República e o Parlamento] de seu principal elemento de força e decisão, que é o mandato notório e inequívoco da vontade popular"43. Essa afirmação não deixa de ser irônica, uma vez que foi emitida por um presidente que implantou um regime de excessão, que extinguiu os partidos políticos e as eleições e que fechou o Congresso por meio da força militar.

De toda forma, a Lei Constitucional $n^{0} 9$ determinou que as datas para novas eleições seriam estipuladas por lei em até três meses. Isso foi feito pelo Decreto-lei n ${ }^{0} 7.586$, de 28 de maio de 1945, conhecido como "Lei Agamenon Magalhães", batizada com o nome do então ministro da Justiça. Assim, estipulava-se a data para as eleições de Presidente, Conselho Federal e Câmara dos Deputados para o dia 2 de dezembro.

\footnotetext{
${ }^{41}$ O que é registrado, entre outros, por Batista Luzardo (CPDOC, GV c 1944.09.08/1), Eurico Dutra (CPDOC, GV c 1944.12.27), Skidmore (1982, p. 72).

$42 \mathrm{Na}$ terminologia do Direito Constitucional brasileiro atual, a Lei Constitucional equivale à Emenda Constitucional. No caso, a Lei Constitucional nº 9 emendava a Constituição Federal de 1937.

${ }^{43}$ Lei Constitucional no 9, de 28 de fevereiro de 1945, preâmbulo.
} 
Além disso, pela mesma lei, os partidos políticos eram recriados, mas, agora, sob bases nacionais. Isso implicava uma diferença fundamental em relação a todo o período da Primeira República, quando os partidos políticos tinham, essencialmente, bases regionais. As poucas tentativas de partidos nacionais, entre 1889 e 1930, haviam sido efêmeras e pontuais, pois visavam, normalmente, à consecução de um único objetivo, após o que se desfaziam.

Para viabilizar a consulta às urnas prevista por esses dispositivos legais, emergiram os três partidos políticos mais importantes dos anos da República Liberal-Conservadora. Assim, em 16 de agosto de 1945, foi registrado junto à Justiça Eleitoral ${ }^{44}$ o Partido Social Democrático (PSD), que lançou o general Eurico Dutra como candidato à Presidência. Em 19 de setembro de 1945, foi a União Democrática Nacional (UDN), lançando como candidato o brigadeiro Eduardo Gomes. Em 26 de março de 1945, foi o Partido Trabalhista Brasileiro (PTB), que não lançou candidato próprio à Presidência, apoiando Dutra ${ }^{45}$.

Em 29 outubro de 1945, foi dado o desfecho final ao Estado Novo, com a destituição de Getúlio Vargas. Naturalmente, esse ato representou o auge do processo de contestação ao regime varguista - e a consolidação do "clamor liberal". Chama-se atenção, no entanto, para a forma por meio da qual Vargas foi deposto: um golpe militar - forma considerada "importantíssima" por Skidmore (1982, p. 78). Ela demonstra a perda de mais uma e, talvez, a mais importante das bases que haviam sustentado o regime desde 1930, os militares.

Essa trajetória ascendente de oposição ao autoritarismo varguista seria um elemento fundamental para a conformação da "imposição do alinhamento". Dessa forma, teria impacto significativo para a formulação da política externa brasileira do pós-1945.

\subsection{O novo e inescapável projeto político: liberalismo}

Como apresentado na seção anterior, o período final do primeiro governo Vargas foi caracterizado por um processo composto por duas forças. Por um lado, havia um "clamor liberal" pela abertura do regime que, gradativamente, ganhava mais ímpeto. Por outro lado, o

\footnotetext{
${ }^{44}$ A Justiça Eleitoral foi recriada em 1945, no processo de abertura do Estado Novo. Precisamente, foi a própria Lei Agamenon Magalhães que regulamentou e que reintroduziu a Justiça Eleitoral.

${ }^{45}$ Como dito, esses três partidos (PSD, UDN e PTB) foram os principais durante a República LiberalConservadora. Isso, no entanto, não significa que foram os únicos. Exemplos de outros partidos foram: Partido Comunista do Brasil, Partido Socialista do Brasil, Partido Democrático Progressista, Partido Democrata Cristão, Partido Republicano, Partido Socialista Cristão, Partido Nacional Evolucionista, Partido de Representação Popular, Partido Libertador, Partido Industrial Agrícola Democrata (ver: www.tse.jus.br).
} 
governo Vargas perdia sua base de sustentação política em uma espiral de insustentabilidade cada vez mais aguda. Naturalmente, essa divisão é, acima de tudo, analítica, uma vez que essas duas forças eram duas faces do mesmo fenômeno de transição política no país.

Nesse contexto, a emergência dos partidos políticos, em 1945, representou mais que uma mera etapa dessa dupla trajetória - "clamor liberal", insustentabilidade varguista. A recriação das agremiação políticas, após seu banimento durante o Estado Novo, significou a institucionalização de um novo e diferente projeto político para o Brasil. Afinal, com sua criação, os partidos políticos institucionalizavam um projeto de nação em seus Programas ou Estatutos, que constituíam verdadeiros manifestos políticos.

A análise e a comparação desses diferentes programas ou estatutos torna ainda mais evidente o movimento de diferenciação ante a Era Vargas, no sentido de mais abertura do regime - ou, em termos político-ideológicos, de mais liberalismo. Nesse sentido, passa-se a analisar comparativamente os manifestos políticos, em sentido amplo, dos três principais partidos políticos do período, nomeadamente UDN, PSD e $\mathrm{PTB}^{46}$.

Antes mesmo de se analisar esses programas diretamente, o que se destaca é a determinação da Justiça Eleitoral de que, para obterem registro eleitoral, os partidos políticos deveriam firmar uma carta de compromisso padrão. Nesta, as agremiações políticas comprometiam-se "ao respeito integral dos princípios democráticos e dos direitos fundamentais do homem"47. Esse compromisso com a liberdade democrática e individual era, por si, um testemunho do "clamor liberal" que seria legado ao novo governo e do ocaso do Estado Novo (ainda em curso), marcado pelo autoritarismo.

Essa tônica liberalizante era verificada, igualmente, nos manifestos políticos dos partidos. De maneira direta, já no primeiro ponto de seu programa, a UDN registrou o objetivo de "atingir a realidade democrática [...] pelo exercício efetivo das liberdades que lhe são inerentes - de pensamento em todas as suas formas de manifestação, de reunião, de associação, de ensino, de religião e de culto e de organização partidária e sindical".

É verdade que era de se esperar uma afirmação tão categórica do partido percebido (e declarado) como mais opositor à herança varguista. A questão é que esse tipo de afirmação

\footnotetext{
${ }^{46}$ Todas as fontes primárias mencionadas nesta seção foram obtidas junto ao Tribunal Superior Eleitoral, seja por meio de consulta ao sítio eletrônico (ver: www.tse.jus.br), para os documentos referentes à UDN e ao PSD; seja por meio de requisição direta ao órgão, para os documentos referentes ao PTB.

${ }^{47}$ Letra d, $\S 2^{\circ}$ do Art. $2^{\circ}$ das "Instruções sobre partidos políticos", Diário da Justiça, 10 de julho de 1945.
} 
não ficou restrita à UDN. Manifestações similares foram pronunciadas tanto pelo PSD quanto pelo PTB, partidos que Fausto (2013, p. 106) caracteriza como vertentes do getulismo.

Nesse sentido, em relação à abertura do regime, o PSD defendia, já no primeiro ponto de seu programa, a "revisão da Constituição, consubstanciando os princípios de regime democrático, social e federativo". Era igualmente claro quanto às liberdades individuais, conforme se depreende do segundo ponto do programa: "a Constituição deverá assegurar [...] a inviolabilidade dos direitos concernentes à liberdade, ao domicílio, [...] à segurança individual e à propriedade, nos termos da tradição constitucional brasileira".

Mesmo o PTB, ainda que de maneira mais tímida, pronunciou-se de modo similar. No ponto 2 de seus "princípios e objetivos", defendeu a "unidade nacional sob regime democrático, com voto direto e universal". Apesar disso, a questão da topografia do artigo colocado em segundo lugar - evidenciava que havia uma preocupação maior, registrada em seu ponto 1: "reexame da Constituição sem que sejam reduzidos os direitos por ela assegurados aos trabalhadores". Apesar disso, mesmo o relutante PTB, para quem a prioridade eram os direitos sociais e não os individuais, teve de se render ao "clamor liberal" de seu período, que demandava, entre outras coisas, a abertura do regime.

No tocante à nova organização econômica do Estado, encontra-se nos programas dos partidos políticos postura muito próxima à verificada na Carta de Teresópolis, no sentido de que a "democracia política" deveria estar acompanhada da "democracia econômica". De maneira similar, defendiam maior protagonismo privado e menor atuação estatal.

Quase copiando os termos da Carta das classes produtoras, o PSD defendeu a "ação do Estado no setor econômico, para, em princípio, orientar e estimular a iniciativa privada e manter ambiente propício ao seu desenvolvimento". À semelhança da Carta, consagrava-se o caráter subsidiário da atuação estatal. Quanto aos capitais estrangeiros, posicionava-se pelo estímulo à segurança conferida a eles, postura que se coadunava com a dos investidores internacionais. Em relação à política alfandegária, verifica-se uma posição mais ambígua, que tentava conciliar a "defesa da economia, principalmente no período de sua consolidação" e o "interesse do consumidor nacional".

Nesse aspecto, o programa da UDN, como era de se esperar, subiu mais na escada do liberalismo - embora, como se demonstrará, não adotou uma postura liberal extremada. Primeiramente, defendia o apelo ao "capital estrangeiro, necessário para os empreendimentos 
da reconstrução nacional e, sobretudo, para o aproveitamento das nossas reservas inexploradas". Demandava, igualmente, a "redução dos direitos aduaneiros". Em relação à intervenção do Estado, ela seria admitida para, além de questões de segurança, "a elaboração, ouvidas as classes interessadas, dos planos que favoreçam o desenvolvimento dos diversos setores da economia". Daí, extraem-se duas conclusões. A primeira era o caráter subsidiário da atuação estatal na economia (e na sociedade). A segunda era que nem a UDN era adepta de um liberalismo rigorosamente ortodoxo, traduzido em um Estado mínimo radical. Isso é o que se constata, igualmente, pela leitura de sua posição acerca da industrialização: "as indústrias estratégicas ficarão a cargo do Estado ou das empresas organizadas com a sua orientação e, quando possível, participação".

O partido mais reticente em relação à "democracia econômica" era, previsivelmente, o PTB. Essa reticência é verificada mais pelos silêncios do que pelas afirmações do programa. Afinal, havia poucas menções à ordem puramente econômica - desatrelada do plano social. Quando existiam, essas referências eram, normalmente, ambíguas. Assim, assegurava-se ao capital o direito ao lucro, mas com "limite razoável". Reconhecia-se que a atuação do Estado deveria dar-se pela "orientação, intervenção ou gestão", mas, ao mesmo tempo, informava que essa atuação estatal (nessas diferentes modalidades) deveria promover a "planificação econômica atingindo todos os setores". Dessa forma, havia poucas concessões à abertura da ordem econômica, que deveria estar orientada prioritariamente aos direitos sociais - ou, mais especificamente, aos direitos trabalhistas.

Por fim, em relação à política internacional, os programas dos três partidos eram notadamente semelhantes - formal e materialmente. Em termos formais, todos os programas eram especialmente curtos no tema. Nesse sentido, a quantidade de pontos sobre política externa era de 3 nos programas do PTB e do PSD e apenas 1 no programa da UDN. Em termos materiais, os programas eram quase idênticos, pois todos defendiam a paz e a cooperação internacional entre os povos, algo coerente com a tradição brasileira e o espírito do tempo - de fim da Segunda Guerra Mundial.

Fora isso, há duas particularidades. Primeira, no programa da UDN, havia a defesa dos "postulados das Nações Unidas" e da "integração da comunidade das Nações americanas". Ambos os preceitos podem ser lidos como manifestos liberais. Por um lado, a ONU foi erigida sob uma base fortemente influencia pelo liberalismo - em suas mais diversas formas, 
como liberdade individual, política, religiosa etc. Por outro lado, o registro à "comunidade das Nações americanas" pode ser interpretado como uma referência cifrada, mas praticamente explícita, ao desejo de maior aproximação com os Estados Unidos, dada a relativa desimportância efetiva dos outros países do continente para o Brasil. Em seu conjunto, essas prescrições quanto à política externa eram coerentes com o perfil político da UDN.

A segunda particularidade, por sua vez, é verificada no programa do PTB. Trata-se do princípio da "ação permanente para que o totalitarismo, sob qualquer aspecto, não possa reaparecer sobre a terra, considerando qualquer regime de força como um atentado à dignidade humana". Esse preceito traz interpretações interessantes, devido ao fato de ter sido emanado pelo partido que acolheu o antigo ditador Getúlio Vargas. Primeiramente, pode ser lido como uma afirmação de que o Estado Novo não havia sido um regime totalitário - o que encontra eco na literatura, que interpreta esse governo como um regime autoritário, e não totalitário (FAUSTO, 1999). Igualmente, estar-se-ia negando que o Estado Novo teria sido um regime de força. Independentemente da interpretação, esse princípio apresenta, de maneira incisiva, aproximação com os ideais liberais, algo que seria muito mais coerente de se encontrar no programa da UDN que no do PTB. Constitui, dessa forma, mais uma concessão ao inevitável liberalismo da época.

A partir do exposto, verifica-se que a análise dos programas, dos estatutos e dos manifestos dos três principais partidos do período (PSD, UDB e PTB) demonstra a existência de uma manifesta, deliberada e institucionalizada diferenciação ante o regime que se aproximava de seus últimos dias, o Estado Novo. Em consequência, esses documentos apontavam para a emergência de um regime mais aberto, sob o influxo inescapável do liberalismo. Afinal, mesmo os mais relutantes, de alguma maneira e em alguma medida, acabavam cedendo ao fato inescapável da marcha rumo à abertura do regime - nos âmbitos social, político e econômico. Dessa forma, as três agremiações políticas atestavam a corrente liberalizante que impactava o Brasil e o mundo ocidental nesse período.

\subsection{Conclusões parciais}

O presente capítulo destacou as transformações que ocorriam nos cenários nacional e internacional. A análise dessas transformações permite que se compreendam os fatores que 
foram postos à época e que contribuíram para formação da política externa brasileira do pós-1945. É, assim, uma tentativa de empreender trajetória inversa a muitos estudos contemporâneos, que analisam essa política externa retrospectivamente, com os olhos de hoje.

Não se quer negar o alinhamento dessa política externa brasileira do pós-1945. Procura-se, sim, argumentar que o esse alinhamento foi resultante do pleno exercício do poder soberano nacional, que não esteve submetido ao jugo de nenhuma potência imperial estrangeira. Tratou-se de uma escolha decorrente da autonomia decisória nacional ante os fatores internos e externos que se colocavam ao país.

No plano externo, os principais fatores foram o fim da Segunda Guerra Mundial, com a vitória das forças Aliadas, que se colocavam contra os regimes totalitários; a emergência da sociedade internacional mundial, que punha fim à sociedade internacional europeia (WATSON, 1992); o surgimento das duas superpotências mundiais, Estados Unidos e União Soviética, que, gradativamente, constituíam uma ordem bipolar que cobrava filiação dos outros países; o ocaso das antigas potências europeias e as várias consequências correlatas.

No plano nacional, os principais fatores foram a escalada tanto das forças liberais quanto da contestação ao regime varguista, que unia uma ampla frente de forças heterogêneas congregadas, essencialmente, pela oposição ao autoritarismo; a emergência da República Liberal-Conservadora, símbolo maior dessa trajetória interna fundadora.

Em termos político-ideológicos, esses fatores podem ser traduzidos como uma afirmação do liberalismo. Desse modo, o fim do primeiro governo Vargas foi marcado por um ambiente interno, recebendo influxos também do ambiente externo, em que a principal característica foi o "clamor liberal". A magnitude desse clamor foi não apenas registrada, mas também institucionalizada nos programas dos três principais partidos políticos da República Liberal-Conservadora: PSD, UDN e PTB. Mesmo este, cujo principal líder era o próprio expresidente Getúlio Vargas, teve de fazer concessões à trajetória que se impunha ao país de abertura política, econômica, social - ou, em outros termos, de "clamor liberal".

Esse compromisso - oficial, inclusive - com a abertura do regime foi o marco de referência fundamental entre esses dois períodos da história do Brasil. Antes dele, havia o autoritarismo do Estado Novo varguista. Depois dele, emergiu a República LiberalConservadora em negação ao passado imediato. Essa negação era o elemento que conferia ao novo regime a justificativa político-ideológica para sua fundação. 
É diante desse contexto - interno e externo - que o liberalismo haveria de ser um aspecto preponderante do novo regime. Assim, não à toa, no governo seguinte, dar-se-ia a "imposição do liberalismo" sobre a política externa brasileira. 
Capítulo II

\section{Imposição do alinhamento: o governo Dutra}

No presente capítulo, passa-se a analisar como a "imposição do alinhamento" se operou durante o governo do general Eurico Dutra (1946-1950). Para tanto, duas ideias são centrais. Primeira, diante do "clamor liberal", não havia alternativas exequíveis ao alinhamento aos Estados Unidos, de modo que essa política não foi uma opção de Dutra, mas uma imposição do período. Segunda, embora tenha havido alinhamento, não se pode afirmar que ele foi absoluto, pois também se verificaram manifestações de resistência, o que apõe matizes à ideia de alinhamento incondicional.

A partir dessas ideias estruturantes, a "imposição do alinhamento" é analisada segundo duas perspectivas: uma positiva e outra negativa. Na positiva, a imposição é constatada por meio da ocorrência de comportamento alinhado. Na negativa, a imposição é verificada pela resistência ao alinhamento. É a soma de ambas as perspectivas que permite se afirmar a existência da imposição. Afinal, se não há qualquer comportamento, mesmo que omissivo, não há nada imposto; e se não há resistência, tem-se aceitação, e não imposição.

Por oportuno, registra-se que essa divisão analítica, apesar de dicotômica, comporta um gradiente bastante amplo de matizes. Assim, na perspectiva positiva, encontram-se comportamentos com graus diversos de alinhamento; enquanto, na perspectiva negativa, há a mesma variação em relação ao grau de resistência dos comportamentos apresentados.

Por meio da análise desses comportamentos, objetiva-se discutir se, durante o governo do general Eurico Dutra (1946-1950), a política externa brasileira teria sido caracterizada por uma espécie de "imposição do alinhamento". Para tanto, a análise está decomposta em três partes. A primeira é a derivação dos elementos do cenário internacional que contribuíram para a formação da política externa brasileira. A segunda é a identificação de episódios de adoção do alinhamento, em variados níveis, aos Estados Unidos (perspectiva positiva). Por fim, a terceira é a investigação de episódios de resistência, em graus diversos, a esse alinhamento (perspetiva negativa). Com isso, procura-se evidenciar como as opções à inserção internacional do Brasil naquela época foram restringidas. Como será visto, o alinhamento impôs-se - por fatores tanto internos quanto externos. 
Além disso, a pesquisa quanto às perspectivas positiva e negativa da imposição permite outro ganho analítico. No capítulo anterior, argumentou-se que muitas das análises sobre a política externa de Dutra (1946-1950), ao reificarem (DUROSELLE, 2000) o conceito de alinhamento sem recompensas (MOURA, 1990), se fundamentam em uma premissa frágil. Nomeadamente, baseiam-se na ideia de que havia alternativas viáveis ao alinhamento e que, portanto, a política alinhada foi uma opção deliberada do ex-ministro da Guerra, em detrimento de outras possíveis. Neste capítulo, acrescenta-se outro elemento à necessidade de apor ressalvas a essas análises. Trata-se da incorporação da resistência ao alinhamento (perspectiva negativa) como variável no presente estudo.

Argumenta-se que muitas das análises acerca desse período se atêm à perspectiva positiva da imposição (comportamentos alinhados). Em consequência, negligenciam as manifestações de resistência (perspectiva negativa). Isso permite que construam narrativas bastante coerentes, pois simplificam a realidade ao ponto de criarem interpretações dicotômicas rígidas, sem ponderações. Ecoam o diagnóstico de Visentini (2013b, p. 198), que se refere a Dutra como "um dos governos que mais se submeteu aos interesses estrangeiros, particularmente norte-americanos", o que é endossado, em alguma medida, por Bueno e Cervo (2012), Cervo (2007, 2008a), Bandeira (1973, 2003). Apesar dessa coerência, são narrativas mais incompletas, pois negligenciam a complexidade e as nuances desse governo.

O conceito de "imposição do alinhamento" permite complementar essas análises. Afinal, os comportamentos alinhados são apresentados e analisados conforme seus diferentes matizes. Os comportamentos de resistência, em suas variadas nuances, são investigados e incorporados ao estudo. Por fim, os elementos do contexto internacional que contribuíram para a política externa são considerados de maneira prospectiva.

\subsection{Elementos do contexto internacional para a imposição do alinhamento}

Como dito, a "imposição do alinhamento" ocorreu pela confluência entre elementos externos e internos que limitaram as opções de inserção internacional do Brasil. Dessa descrição, verifica-se que se faz necessária uma análise dos contextos internacional e nacional. Este será investigado em seções seguintes, que, por sua vez, também serão decompostas em duas partes: a perspectiva positiva (exercício) e a perspectiva negativa 
(resistência) da "imposição do alinhamento". O contexto internacional, a seu turno, é investigado nesta seção, visando a depreender os principais elementos do cenário internacional que contribuíram para a conformação da política internacional brasileira durante o governo Dutra (1946-1950).

No âmbito internacional, o principal elemento a contribuir para a "imposição do alinhamento" foi a Guerra Fria, que, conforme lembra Cervo (2008a, p. 95), se constituiu como variável sistêmica no período. Afinal, o condomínio de poder sobre as relações internacionais que Estados Unidos e União Soviética exerceram - dois gigantes e um condomínio (SARAIVA, 2008, p. 197) - reduziu o espaço de atuação dos Estados na arena internacional, pois cobrou-lhes filiação a um dos grupos (ENGERMAN, 2010; GADDIS, 2005a; GADDIS, 2005b).

Isso posto, pode-se analisar a interação entre a política externa brasileira e a Guerra Fria segundo o que Ian Clark (2005, p. 131) conceituou como o arranjo dual de 1945 (the dual settlement of 1945). A dualidade desse arranjo é dada por Ikenberry (2001, p. 163-170), para quem a ordem internacional do pós-guerra foi caracterizada pela bipolaridade e pela ocidentalização.

Por bipolaridade, define-se a relação entre Estados Unidos e União Soviética, baseada na balança de poder, na dissuasão nuclear e na competição política e ideológica. Culminou no "sistema de contenção" (GADDIS, 2005b), que foi o mecanismo mais militarizado da história. Por ocidentalização, compreende-se o processo desencadeado pela configuração e pela expansão do polo capitaneado pelos Estados Unidos, no qual se incluíam os países ocidentais e o Japão. Seus fundamentos eram abertura econômica, reciprocidade política e administração multilateral de uma ordem política liberal capitaneada pelos Estados Unidos. Culminou em uma ampla rede de novas instituições entre os integrantes dessa ordem.

Assim, adotando-se a ideia de arranjo dual de 1945 (CLARK, 2005, p. 131), o Brasil de Dutra tinha de responder a esses dois arranjos. Por um lado, tinha de posicionar-se perante o conflito bipolar, associando-se a um dos blocos. Por outro, dada a filiação ao bloco norteamericano, tinha de espelhar, em alguma medida, os valores, os princípios, as instituições que correspondiam à ocidentalização. Nesse contexto, a "imposição do alinhamento" operava. 


\subsubsection{A bipolaridade como imposição}

A Guerra Fria contribuiu, de maneira significativa, para a limitação das opções de política externa do Brasil no imediato pós-1945, pois as superpotências fundaram sua influência sobre projetos universalistas. Nesse sentido, Estados Unidos e União Soviética viam-se e impunham-se como portadores de ideias válidas para qualquer povo, lugar ou tempo. Aprofundadas, essas ideias - liberdade individual, anticoletivismo e economia de mercado, pelos norte-americanos; e justiça social, coletivismo e planejamento estatal, pelos soviéticos - cristalizaram-se em ideologias $^{48}$ rivais (WESTAD, 2010; HALLIDAY, 1986).

Apesar de rivais, essas ideologias tinham, pelos menos, duas características comuns (ENGERMAN, 2010, p. 31-32). A primeira é apresentarem natureza universalista, messiânica e determinista. Assim, cada bloco via a si como a encarnação do fim da história ${ }^{49}$, como o destino inexorável e final da humanidade - o que era reverberado por lideranças no Brasil.

Isso pode ser depreendido, por exemplo, em discursos dos respectivos líderes das duas superpotências. Assim, em 11 de outubro de 1948, Truman identificou a república norteamericana como "the greatest in history, the greatest that the sun has ever shone upon"50. Semelhantemente, em 9 de fevereiro de 1946, Stalin afirmo já ter sido provada a viabilidade do sistema soviético, de modo que o que se punha então era "that the Soviet social system has proved to be more viable than the non-Soviet social system, that the Soviet social system is a better form of organization of society than any non-Soviet social system" ${ }^{51}$.

A segunda característica em comum é o fato de que cada bloco identificava o rival como uma ameaça. Assim, para os norte-americanos, a União Soviética seria um perigo, pois era totalitária (STEPHANSON, 2005, p. 58). Paralelamente, para os soviéticos, os Estados Unidos eram ameaçadores, pois o regime econômico que adotavam, o capitalismo, tinha como consequência lógica o fascismo (KENNAN, 1947, p. 566).

\footnotetext{
${ }^{48}$ Entende-se ideologia como "sistemas de crenças explícitas, integradas e coerentes, que justificam o exercício do poder, explicam o que é bom e o que é mau em política, definem as relações entre política e outros campos de atividade, e fornecem uma orientação para a ação" (BOBBIO; MATTEUCCI; PASQUINO, 1998, p. 587).

${ }^{49}$ Expressão que ganhou notoriedade com as obras homônimas de Fukuyama (1989, 1992).

${ }^{50}$ Harry Truman, "Rear platform and other informal remarks in Ohio" (11 de outubro de 1948).

${ }^{51}$ Stalin (1954, p. 27).
} 
Essas características implicaram a diminuição do espaço de atuação para a diplomacia brasileira. Afinal, se cada ideologia (norte-americana, soviética) era universalista, messiânica e determinista - consubstanciando, em essência, o fim da história - a adoção de uma estava associada à exclusão da outra. Isso é ainda mais verdadeiro quando se adicionava rivalidade a esse arcabouço ideacional. Assim, a ideologia não adotada se tornava não apenas incorreta, mas também inimiga. Nesse contexto, naturalmente, diminuíam-se as opções para a inserção internacional (CERVO, 2008a) do Brasil.

O cenário de formação da Guerra Fria é apresentado de maneira um pouco distinta por Frank, Girault e Thobie (1993, p. 90-92). Para esses autores, a ideologia foi a arma utilizada pela União Soviética, enquanto os Estados Unidos se valeram do dólar. Essa diferença seria derivada da situação distinta com que os dois países emergiram da Segunda Guerra Mundial.

Os Estados Unidos sofreram relativamente poucas perdas humanas - nomeadamente, 300.000 (FRANK; GIRAULT; THOBIE, 1993, p. 91) - e contavam com duas "armas essenciais": bomba atômica e dinheiro. A diplomacia atômica, no entanto, tinha limites, pois não podia ser empregada livremente, sob pena de destruir os próprios aliados. Por isso, muito mais relevante foi o papel desempenhado pela "arma econômica", segundo Frank, Girault e Thobie (1993, p. 90-92). O espaço de atuação nesse âmbito era bastante amplo, pois o PIB dos Estados Unidos aumentou em quase 80\% em apenas 5 anos, saindo de US\$ 930.828 milhões, em 1940, para US\$ 1.646 .690 milhões, em 194552. Aliado a isso, o continente europeu saiu devastado da guerra, de modo que a assistência financeira lhe era imperativa.

A União Soviética estava em situação contrária. Foi o país que mais sofreu em termos de perdas humanas na Segunda Guerra Mundial, com mais de 20 milhões de nacionais mortos (SARAIVA, 2008, p. 199). Ainda, assistiu ao aumento da distância entre sua economia e a norte-americana, não apenas por esta ter aumentado, mas também por ter a soviética diminuído. Nomeadamente, o PIB da União Soviética caiu de US\$ 420.091 milhões, em 1940, para US\$ 333.656, em $1945^{53}$ - ou seja, para aproximadamente $20 \%$ do PIB dos Estados Unidos. Por fim, os soviéticos só adquiriram arma atômica em 1949, tendo de aceitar o monopólio atômico norte-americano até essa data. É nesse contexto que a principal arma dos soviéticos teria sido a ideologia (FRANK; GIRAULT; THOBIE, 1993, p. 92).

\footnotetext{
${ }^{52}$ Em valores de 1990 (IKENBERRY, 2001, p. 279).

${ }^{53}$ Ibidem.
} 
Diante dessa caracterização de Frank, Girault e Thobie (1993), duas observações são levantadas. Primeira, ainda que ela seja adotada, não há alterações significativas para a situação da política externa brasileira. Afinal, as armas "atômica" e "econômica" norteamericanas só confirmariam a restrição das possibilidades para o Brasil. Este, situado no continente da superpotência ocidental, ver-se-ia cooptado pela pujança econômica dos Estados Unidos e oprimido e/ou defendido pela força atômica destes.

Segunda, em que pese a coerência dessa narrativa, argumenta-se que a dicotomia dólar-ideologia (FRANK; GIRAULT; THOBIE, 1993, p. 90-92) é apenas aparente, pois o dólar não era neutro ideologicamente. Assim, seu uso também tinha valor diplomáticoideológico para os Estados Unidos, na mesma medida em que o rublo, para a União Soviética. A economia, nesse sentido, foi um dos elementos do conflito entre ideologias, utilizada para demonstrar a superioridade de seus modelos (ENGERMAN, 2010, p. 41), baseados, respectivamente, na economia de mercado e na planificação estatal (MAIER, 2010, p. 46).

É assim que êxitos econômicos no Japão e na República Federal da Alemanha, de um lado, e na Índia e no Egito, de outro, foram apresentados como índices de sucesso (ou de "comprovação da veracidade") das ideologias em disputa (ENGERMAN, 2010, p. 41). Do mesmo modo, foi nesse contexto que se inseriram medidas como o Plano Marshall, de 1947, e o Conselho para a Assistência Econômica Mútua, de 1949.

Dessa forma, a força do dólar (ou do rublo) estava intimamente associada à força da ideologia capitalista (ou comunista). Portanto, o dólar era mais um dos elementos dicotômicos da bipolaridade da Guerra Fria - Estados Unidos x União Soviética, capitalismo x comunismo, Ocidente x Oriente, liberdade de mercado x planificação - em relação aos quais cabia o Brasil posicionar-se.

Ainda, há de se considerar que as medidas tomadas por norte-americanos e soviéticos não se restringiam ao objetivo único de promover o desenvolvimento em outros países como instrumento persuasão. Assim, apresentavam, também, forte caráter pragmático, servindo ao próprio desenvolvido dos Estados Unidos e da União Soviética. Especificamente ao primeiro, Saraiva (2008, p. 200) informa que a Guerra Fria atendia a interesses da indústria e do comércio norte-americanos, pois permitia a continuidade ao "impulso desenvolvimentista" verificado na Segunda Guerra Mundial. 
O reconhecimento de que havia interesses materiais específicos em jogo não invalida, todavia, a afirmação de que, como disputa ideológica, a Guerra Fria era uma batalha para "ganhar corações e mentes". Essa, inclusive, foi a expressão utilizada pelo presidente John Kennedy no contexto da reação norte-americana à Revolução Cubana, visando a evitar que a influência comunista se espalhasse na América Latina (FERNANDES, 2009, p. 835). Desse modo, verifica-se que a Guerra Fria foi uma batalha por influência, medida pela capacidade de persuasão dos Estados Unidos e da União Soviética em consolidar seus domínios e em atrair novas adesões a seus respectivos blocos (WATSON, 1992, p. 292), o que reforça o argumento de que as opções internacionais para o Brasil eram restritas.

Isso é ainda mais evidente quando se considera que, em muitos casos, a persuasão foi efetivada por meios militares, de modo que, na prática, não houve contradição entre esses dois elementos, mas complementaridade. A relação, na Guerra Fria, entre esses elementos foi caracterizada de maneira bastante feliz por Engerman (2010, p. 41), que retrata as duas superpotências "seeking persuasion over conquest - but when necessary using conquest as a tool for persuasion".

Acerca disso, também se deve considerar que, quando os meios militares eram empregados, eles o foram de modo específico na Guerra Fria. Afinal, como aponta Engerman (2010, p. 32), a Guerra Fria era fria ${ }^{54}$ porque, diferentemente das guerras anteriores, não havia confronto militar direto entre os polos beligerantes ${ }^{55}$, Estados Unidos e União Soviética, embora essa possibilidade fosse sempre presente. Nesse contexto, quando se recorria aos meios militares, eles eram empregados nas margens: nas respectivas zonas de influência ou em terra nullius ${ }^{56}$ - zonas que ainda não apresentavam filiação ideológica definida. Assim, em reforço à retórica ideológica - na qual se incluía a econômica -, havia a possibilidade de conflitos militares a influir sobre as considerações quanto à política externa brasileira.

Naturalmente, a ideia de destruição mútua assegurada (mutual assured destruction, MAD) contribuiu para a lógica de "conflito indireto" (HOBSBAWM, 1995, p. 226). Afinal,

\footnotetext{
${ }^{54}$ Hobsbawm (1995), inclusive, prefere referir-se à paz fria, em oposição à guerra quente. McMahon (2003), a exemplo de outros autores, prefere caracterizar a Guerra Fria por momentos quentes e frios.

${ }^{55}$ Conforme se analisará no próximo capítulo, Gaddis (2005a, p. 60) apõe ressalvas à ideia de que não teria havido confronto direto entre Estados Unidos e União Soviética, durante a Guerra Fria. De toda forma, é possível admitir essa ideia como, pelo menos, uma característica geral da Guerra Fria.

${ }^{56} \mathrm{Na}$ definição técnica oferecida pelo Direito Internacional, terra nullius é uma expressão latina, originária do Direito Romano, que significa "terra de ninguém". Como não tem dono, essa terra está sujeita à "conquista", que já foi um modo legítimo de aquisição de território (MARTIN, 2002, p. 154).
} 
acreditava-se que, se uma das superpotências iniciasse um ataque direto contra a outra, haveria retaliação imediata, de modo que, ao final, ambas sairiam destruídas (CORTEZ; LOBO, 2015, p. 43). Essa ideia adquiriu contornos concretos a partir de 1949, quando a União Soviética alcançou sua bomba atômica; e, no final do governo Kennedy, a dissuasão mútua - forma de evitar a MAD - tornou-se "doutrina oficial", na esteira da Crise dos Mísseis, de 1962 (MCMAHON, 2010, p. 310). Nesse sentido, o discurso de despedida de Truman, de 1953, é ilustrativo quanto à percepção do potencial destrutivo de uma nova guerra, no qual informa que "a third world war might dig the grave not only of our Communist opponents but also of our own society, our world as well as theirs"57.

Assim, verifica-se o temor quanto à emergência de uma eventual Terceira Guerra Mundial. Cria-se que, se houvesse um novo conflito entre as potências, ele seria o último, pondo cabo às civilizações ou até à própria humanidade.

É oportuno registrar que esse temor foi uma constante no imaginário político já a partir do imediato pós-Segunda Guerra Mundial. Isso é constatado, por exemplo, no comunicado de renúncia do cargo de embaixador dos Estados Unidos na China que Patrick Hurley enviou ao presidente Harry Truman, em 26 de novembro de 1945: "there is a third world war in the making. In diplomacy today we are permitting ourselves to be sucked into a power bloc on the side of colonial imperialism against Communist imperialism" 58 .

Nesse contexto de destruição mútua assegurada e de ameaça constante do fantasma da Terceira Guerra Mundial, o "conflito indireto" emergiu como modus operandi tácito. Dessa forma, seguiram-se as intervenções estadunidenses e soviéticas em diversas áreas do globo um elemento a mais a contribuir na formação da política externa brasileira do pós-1945.

Essas intervenções não se fizeram tardar, surgiram logo após o fim da Segunda Guerra Mundial. Especificamente em relação às norte-americanas, elas já se verificaram em outubro de 1945, quando os Estados Unidos enviaram 50 mil marines para a China - onde já havia um contingente de aproximadamente 60 mil fuzileiros navais -, com vistas a robustecer as forças de Jiang Jieshi, do Kuomitang (GRIMMETT, 2010, p. 11). A partir de 1945 também, houve intervenções norte-americanas na política doméstica italiana, onde apoiaram a Democracia Cristã, como exemplifica o empréstimo de US\$ 100 milhões concedido por Truman a De

\footnotetext{
${ }^{57}$ Harry Truman, "The president's farewell address to the American people" (15 de janeiro de 1953).

${ }^{58}$ FRUS, "123 Hurley, Patrick" (25 de novembro de 1945).
} 
Gasperi, na viagem deste aos Estados Unidos, em janeiro de 1947 (MARTINEZ OLIVA, 2007, p. 10). Ainda nesse momento inicial, teve destaque o caso das Filipinas, onde os Estados Unidos, após conceder-lhe a independência em 1946, atuaram para fazer frente ao desafio comunista posto pelos Huks, que iniciaram uma escalada revolucionária (HUNT; LEVINE, 2005, p. 255-257).

Esses ataques iniciais serviram de ensaio para a formação da estratégia de contenção norte-americana, cujo ideólogo principal nessa época foi George Kennan. Foi ele que, no artigo The sources of Soviet conduct, publicado na Foreign Affairs, em 1947, levou ao mundo o conceito de contenção (GADDIS, 2005b, p. 25). A estratégia de contenção também contribuiu para reduzir as opções de atuação internacional do Brasil. Afinal, como o próprio nome sugere, essa estratégia visava a reforçar as barreiras entre os dois mundos, o capitalista e o comunista (GADDIS, 2005b).

Como visto no capítulo anterior, a estratégia de contenção foi desencadeada, de modo imediato, para conter a expansão da influência soviética sobre o Mediterrâneo oriental, especificamente sobre a Grécia e a Turquia. Na Grécia, vivia-se uma guerra civil entre grupos comunistas (principalmente, o Partido Comunista Grego) e anticomunistas (forças leais ao rei Georgios Papandreou), após a expulsão do exército alemão (RAJAK, 2010, p. 203). Na Turquia, Stalin pressionava pelo domínio partilhado do Estreito de Bósforo (RAJAK, 2010, p. 207), passagem que se inseria entre os objetivos geopolíticos russos desde, pelo menos, a Guerra da Crimeia (1853-1856). Ante a incapacidade do Reino Unido de continuar apoiando as forças aliadas nesses dois países (SARAIVA, 2008, p. 200), coube aos Estados Unidos a defesa dos interesses ocidentais nos Balcãs.

Desse modo, consolidou-se, definitivamente, o término da sociedade internacional europeia (WATSON, 1992). Afinal, em 1947, com sua saída da Grécia e da Turquia e com o reconhecimento das independências da Índia e do Paquistão, os britânicos renunciavam à primazia militar que haviam exercido sobre as relações internacionais desde a Revolução Industrial. Assim, o Reino Unido perdia espaço no próprio entorno imediato, a Europa, cimentando tendência que, na América, ocorria desde o pós-Primeira Guerra Mundial (GARCIA, 2002), nomeadamente sua substituição como centro de poder pelos Estados Unidos. Este país, consequentemente, consolidou sua liderança sobre bloco ocidental no contexto da era das superpotências (WATSON, 1992). 
Essa liderança manifestou-se por meio tanto de empréstimos ou doações quanto de intervenções militares. Em todos os casos, havia forte conteúdo ideológico nas ações. É o que se depreende, por exemplo, do discurso que inaugurou essa nova etapa (a Doutrina Truman), proferido pelo presidente Harry Truman no Congresso norte-americano, em 12 de março de 1947: "we shall not realize our objectives, however, unless we are willing to help free peoples to maintain their free institutions and their national integrity against aggressive movements that seek to impose upon them totalitarian regimes"59. Dessa forma, concluiu que "it must be the policy of the United States to support free peoples. [...] I believe that we must assist free peoples to work out their own destinies in their own way".

Optou-se, nesta seção, por privilegiar a expansão da zona de influência norteamericana (bloco ocidental), pois foi a ela que o Brasil se filiou. De toda forma, no bloco oriental, capitaneado pela União Soviética, a situação não foi diferente, na medida em que também houve esforços militares, financeiros e políticos pelos soviéticos para expandir e consolidar sua área de atuação e controle.

Sucintamente, registra-se que a sovietização da Europa do Leste se completou grosso modo entre 1947 e 1948 (NAIMARK, 2010, p. 183-184). Esse processo teve nos anos de 1944 e 1945 seu momento de formação (NAIMARK, 2010, p. 177), com o estabelecimento de governos comunistas, normalmente, em substituição ao domínio nazista. A partir de então, a expansão soviética ocorreu em ritmo vigoroso. Nesse sentido, basta lembrar que, até 1948, ficaram sob controle soviético, direta ou indiretamente: Polônia, Checoslováquia, Hungria, Romênia, Iugoslávia, Bulgária e Albânia - registrando que os quatro últimos países foram não apenas satélites, mas também "repúblicas populares", o que atesta a plena fíliação deles ao mundo comunista. Além disso, ainda nesse momento inicial até 1948, foram ocupados, total ou parcialmente, os territórios das Ilhas Curilas - que, até hoje, são russas -, da Áustria, da Península da Coreia e da Alemanha.

Em relação ao último território, o da Alemanha, ele representou o momento mais tenso nas relações entre Estados Unidos e União Soviética, nesse período inicial da Guerra Fria. Constituiu uma demonstração de força pelos dois lados, como exemplifica o bloqueio soviético de Berlim em 1948, contornado pelos norte-americanos e pelos britânicos com o envio contínuo de mantimentos por transporte aéreo (SARAIVA, 2008, p. 206), o que ficou

\footnotetext{
${ }^{59}$ Harry Truman, "Recommendation for assistance to Greece and Turkey" (12 de março de 1947).
} 
conhecido como Operação Little Vittles. Na esteira do levantamento do bloqueio, em 1949, formalizou-se a divisão da Alemanha em blocos ideológicos distintos, com a fundação da República Federal da Alemanha (Alemanha Ocidental) e da República Democrática Alemã (Alemanha Oriental). Assim, o mapa da Europa na Guerra Fria ficou demarcado, tendo como linha divisória a Cortina de Ferro (ENGERMAN, 2010, p. 39).

A partir desse cenário, não surpreende que se tenham formado blocos militares antagônicos em torno das superpotências, contribuindo para conformar o que Ian Clark (2005) caracterizou como o arranjo mais militarizado da história. Nesse sentido, Estados Unidos e União Soviética instituíram, respectivamente, a Organização do Tratado do Atlântico Norte (OTAN), em 1949, e o Pacto de Varsóvia, em 1955. Com isso, a Guerra Fria ganhava, oficialmente, sua face militar. Em consequência, aumentava-se o poder de persuasão dos dois blocos antagônicos - inclusive sobre o Brasil.

\subsubsection{O arranjo ocidental}

Em continuidade à análise do arranjo dual de 1945 (CLARK, 2005), passa-se a investigar o arranjo ocidental. Nesse âmbito, destacam-se duas características principais: o domínio dos Estados Unidos e a força do liberalismo. Naturalmente, essas características estavam relacionadas. Optou-se, no entanto, por separá-las com vistas a ganhos analíticos. Assim, analisa-se, individualmente, cada lado da moeda.

\subsubsection{O domínio dos Estados Unidos}

Em relação à primeira característica, muitos de seus elementos já foram apresentados no capítulo anterior e neste. Dessa forma, já se demonstraram o movimento da emergência da superpotência ocidental e o da decadência das potências europeias. Relacionados a esses dois movimentos, já se verificaram os expressivos ganhos econômicos e militares advindos da Segunda Guerra Mundial para os estadunidenses, bem como o monopólio nuclear usufruído por eles até 1949. Nesse cenário, não surpreende que os Estados Unidos tenham tido e exercido tanto influência sobre o bloco ocidental - e, consequentemente, sobre o Brasil. 
Essa influência manifestou-se não apenas sobre pequenas e vulneráveis nações do Mediterrâneo americano (SPYKMAN, 1942), como ocorrera durante a política do grande porrete (CERVO, 2008c), nos tempos de William McKinley e Theodore Roosevelt. No pósSegunda Guerra Mundial, a influência dos Estados Unidos operou-se, mesmo, sobre as outrora grandes potências europeias.

Houve, assim, notável contraste com o quadro verificado na sociedade internacional europeia (WATSON, 1992), quando França, Reino Unido, Rússia e Áustria exerciam hegemonia coletiva sobre as relações internacionais (CERVO, 2008b, p. 49). Afinal, na sociedade internacional global (WATSON, 1992), esses países, à exceção da Rússia - que se tornou uma das duas superpotências mundiais -, ficaram em situação de dependência militar e financeira em relação às superpotências.

No tocante à Áustria e à Alemanha, o melhor testemunho para essa nova situação é o fato de que ambos os países ficaram ocupados por tropas estrangeiras mesmo após a Segunda Guerra Mundial. Quanto ao Reino Unido e à França, o testemunho para a ascendência norteamericana é oferecido, da maneira mais eloquente, pelos próprios ministros das Relações Exteriores desses dois países.

Nesse sentido, o britânico Ernest Bevin reconheceu a inversão de papeis entre Reino Unido e Estados Unidos, afirmando que "the US was in the position today where Britain was at the end of the Napoleonic wars. When those wars ended Britain held about 30 percent of the world's wealth. The US today holds about 50 percent"60. De maneira ainda mais contundente, o francês Georges Bidault confessou a situação da França em relação aos Estados Unidos: "I am very specially grateful in this emergency to all the Americans of both political parties whom I saw in Washington, and who were kind enough not to make me feel the humiliation of my position as a beggar for my country"61.

Esses excertos verbalizavam o estado de extrema dependência aos Estados Unidos que França e Reino Unido viviam - países que, juntos, respondiam por quase 50\% dos recursos oferecidos pelo Plano Marshall (VAÏSSE, 2013, p. 19). Não à toa, Ikenberry (2001, p. 193) informa que a maior preocupação era com o eventual retorno dos norte-americanos ao isolacionismo, e não com a presença hegemônica deles na Europa. Nesse contexto, a ameaça

\footnotetext{
${ }^{60}$ FRUS, "Telegrama 840.00/6-1647" (16 de junho de 1947).

${ }^{61}$ FRUS, "851.51/10-2447" (24 de outubro de 1947).
} 
do comunismo era levantada por europeus como forma de tentar atar os Estados Unidos ao continente (IKENBERRY, 2001, p. 193) - em termos políticos, militares e econômicos.

Esse quadro permite o seguinte questionamento: se até as antigas potências europeias estavam em situação de tamanha dependência em relação aos Estados Unidos, o que se deveria esperar dos outros integrantes do bloco ocidental, em especial na América Latina (e no Brasil)? A resposta a esse questionamento parece evidente: em especial na América Latina (e no Brasil), região tida como área de influência natural dos norte-americanos (SARAIVA, 2008, p. 208), não havia alternativa factível ao alinhamento aos Estados Unidos.

Nesse sentido, mesmo ensaios de autonomia mais incisivos perante os Estados Unidos apresentaram limites. O caso mais notório disso foi o da Argentina do general Juan Domingo Perón (1946-1955). Com viés mais autonomista, Perón declarou que sua política externa seria caracterizada pela Tercera Posición, na qual estaria superada a oposição entre os blocos capitalista e comunista (SANCHÍS MUÑOZ, 2010, p. 327). Apesar disso, Perón também declarou que, em caso de conflito entre Estados Unidos e União Soviética, apoiaria os norteamericanos (PUNTIGLIANO, 2015, p. 89).

Assim, se mesmo para as antigas potências europeias, o exercício de autonomia pleno ante os Estados Unidos era inviável, não era de se esperar algo diferente para os países da América Latina (e para o Brasil), entorno geográfico estadunidense. Não foi, no entanto, apenas o fato de estar na hinterlândia norte-americana que justificou o alinhamento dos latinoamericanos (e dos brasileiros) aos Estados Unidos. Houve, igualmente, interesse material para isso: a expectativa, principalmente no imediato pós-guerra, de que os Estados Unidos continuariam ou mesmo aumentariam o fornecimento de capitais de longo prazo para a região (BETHELL; ROXBOROUGH, 2005, p. 313).

Contra essa expectativa, no entanto, pesou o fato de que a Europa Ocidental e a América Latina saíram em situação bastante distinta da guerra, o que implicou tratamento diferente às duas regiões pelos Estados Unidos. Nomeadamente, os países da América Latina não foram arrasados por aquela guerra total (SARAIVA, 2008, p. 207) e, em consequência, não necessitavam de financiamentos para sua reconstrução interna. Assim, como visto no primeiro capítulo, foram os europeus que, nesse período, drenaram os recursos do Banco Mundial (POLLARD, 1997, p. 81) - cujo nome oficial era Banco Internacional para a Reconstrução e o Desenvolvimento, o que é ilustrativo para demonstrar seu objetivo inicial. 
Além disso, contrariamente ao que ocorria na Europa e na Ásia, não havia ameaça soviética na América Latina. Afinal, nessa época, a União Soviética não tinha nem bomba atômica, nem força aérea de longo alcance, nem marinha eficiente (BETHELL; ROXBOROUGH, 2005, p. 310). Não surpreende, então, que a América Latina tenha tido baixa prioridade estratégica para a política norte-americana do imediato pós-guerra, apesar de iniciativas como o Tratado Interamericano de Assistência Recíproca, de 1947, e a Organização dos Estados Americanos, de 1948.

Essa negligência traduziu-se em números. Assim, dos US\$ 1,3 bilhões concedidos pela Lei de Assistência Mútua para a Defesa, de 1949, nada foi destinado para a América Latina (BETHELL; ROXBOROUGH, 2005, p. 310). Ainda, enquanto a Europa Ocidental recebeu US\$ 19 bilhões em ajuda externa dos Estados Unidos entre 1945 e 1950, a América Latina recebeu apenas US\$ 400 milhões - quantia menor que a recebida por Luxemburgo ou Bélgica, individualmente (BETHELL; ROXBOROUGH, 2005, p. 314).

Houve, ainda, um terceiro elemento que justificou o alinhamento latino-americano (e brasileiro) aos Estados Unidos na Guerra Fria. Como visto no primeiro capítulo, uma das consequências da vitória dos Aliados na Segunda Guerra Mundial foi a abertura política para regimes democráticos. Essa abertura trouxe consigo o acirramento do conflito político-social, uma vez que grupos antes proscritos ou estritamente controlados - como socialistas, comunistas, sindicalistas, entre outros - passaram a disputar o voto popular, com relativo sucesso. Isso assustou grupos conservadores dirigentes na América Latina, que, em reação, se valeram do arcabouço ideológico-discursivo da Guerra Fria para perseguir aqueles grupos de esquerda, rotulados "subversivos", "títeres de Moscou", "antidemocráticos" (BETHELL; ROXBOROUGH, 2005, p. 301-309). Desse modo, o alinhamento ao bloco ocidental foi instrumentalizado, de maneira pragmática, por dirigentes latino-americanos (e brasileiros) na disputa política doméstica.

Por fim, pode-se registrar um quarto elemento para a inserção da América Latina (e do Brasil) na esfera de influência norte-americana. Trata-se, nomeadamente, da tradição histórico-cultural do pan-americanismo, que se fazia sentir, pelo menos, desde o final do século XIX (LE CHAFFOTEC; MORELI, 2015, p. 2). Assim, o alinhamento aos Estados Unidos constituiu mais uma continuidade que uma ruptura na história da região. 


\subsubsection{A força do liberalismo}

Depois do estudo acerca da nova ordem econômica ocidental (BIRD, FMI, GATT) efetuado no primeiro capítulo e após a análise tanto da disputa ideológica da Guerra Fria quanto do bloco ocidental empreendida neste capítulo, tem-se como demonstrado que o liberalismo era a base ideacional que amalgamava a ampla área de influência dos Estados Unidos. Por isso, nesta seção, não se pretende retomar todo esse vasto conjunto de iniciativas que institucionalizaram a crença liberal norte-americana no Ocidente. Pretende-se, sim, fazer uma breve ressalva quanto à natureza do liberalismo que emergiu no pós-1945.

Como lembra Ian Clark (2005, p. 132), após 1945, o mundo ocidental passou a ter sua legitimidade internacional fundada sobre uma nova forma de liberalismo, nomeadamente o embedded liberalism (RUGGIE, 1982). Ele constituía uma nova forma, pois, contrariamente ao liberalismo clássico do padrão ouro e do livre comércio, o embedded liberalism convivia com a intervenção estatal na economia nacional (RUGGIE, 1982, p. 393). Não significava, no entanto, o retorno ao nacionalismo econômico da década de 1930, pois, no embedded liberalism, a ordem econômica seguia diretrizes multilaterais (RUGGIE, 1982, p. 393).

Essa nova forma de liberalismo constituiu, assim, a solução de compromisso entre duas tendências opostas que se verificavam em meados da década de 1940. Por um lado, os defensores da ortodoxia liberal internacionalista, abundantes entre os financistas de Wall Street; por outro, os que rejeitavam a liberdade econômica irrestrita, rejeição essa que era quase universal para além dos Estados Unidos (RUGGIE, 1982, p. 393).

Para se alcançar esse novo liberalismo, foi necessária a passagem da ideia do livre mercado para a da abertura administrada, segundo caracterização de Ikenberry (2001, p. 185). Isso era indispensável para que os norte-americanos alcançassem um acordo quanto à ordem econômica do pós-guerra com os europeus, que estavam mais preocupados com a reconstrução nacional e o desemprego do que com o livre comércio. A solução, então, foi a abertura administrada, fundada sobre uma "barganha social" que buscava equilibrar abertura econômica com seguridade e estabilidade domésticas (IKENBERRY, 2001, p. 185).

Com isso, Ian Clark (2005, p. 140) argumenta que a sociedade internacional se reinventou, pois o embedded liberalism (RUGGIE, 1982) tornou-se elemento central da ordem ocidental. Afinal, ao se difundir, o embedded liberalism (RUGGIE, 1982) incutiu não 
apenas a crença no livre comércio ou mesmo na democracia, mas também uma série de valores, preceitos, instituições, princípios nos países, como o Brasil, integrantes da zona de influência norte-americana.

Assim, liberalismo transmutou-se em ocidentalismo, por meio do qual o pensamento e a prática do Ocidente foram desterritorializados e passaram a ser apresentados como verdades universais, aplicáveis e benéficas a todo e qualquer ser humano (ACHARY; BUZAN, 2010, p. 6-8). Diante desse processo, o liberalismo tornou-se uma força ainda mais premente, o que ajuda a compreender o quadro da "imposição do alinhamento" no Brasil.

\subsubsection{O grau de liberdade no interior do bloco ocidental}

De modo a encerrar a análise acerca do contexto internacional que contribuiria para a conformação da "imposição do alinhamento", passa-se a investigar a natureza da filiação ao bloco ocidental. Especificamente, analisa-se o grau de liberdade que os integrantes - entre os quais se incluía o Brasil - do bloco possuíam perante a superpotência ocidental, os Estados Unidos. Em relação a isso, destacam-se três características.

A primeira associa-se à justificativa para o que Ikenberry (2011) definiu como o mecanismo mais institucionalizado da história. Nesse sentido, os Estados Unidos valeram-se de seu elevado grau de ascendência sobre o bloco ocidental para conformar uma ampla rede institucional de novos organismos nos mais diversos âmbitos. Como visto no primeiro capítulo, essa rede começou a ser tecida ainda durante a Segunda Guerra Mundial, quando já ganhava contornos claros o papel preponderante que os Estados Unidos iriam desempenhar no pós-guerra. Assim, estabeleceram-se o Banco Mundial, o Fundo Monetário Internacional, o Acordo Geral sobre Tarifas e Comércio, o Plano Marshall, o Tratado Interamericano de Assistência Recíproca, a Organização dos Estados Americanos, a Organização do Tratado do Atlântico Norte. Em conjunto, essa rede consolidava a ascendência norte-americana e constrangia a atuação dos integrantes do bloco ocidental.

A segunda característica, por sua vez, associa-se aos dois argumentos principais do influente artigo de Geir Lundestad (1986), referente aos anos entre 1945 e 1952. Primeiro, a expansão dos Estados Unidos nesse período foi tão profunda e alcançou tantas partes diferentes do mundo que seria possível caracterizar sua área de influência como império 
americano. Segundo, de acordo com Lundestad (1986), esse império tinha uma característica específica, nomeadamente: ser um império por convite (empire by invitation). Dessa forma, a influência norte-americana gozava de tal magnitude pelo fato de que seus mecanismos de controle serem mais coerentes com os aspectos das populações locais e, principalmente, porque muitos dos países integrantes do império americano demandavam a presença dos Estados Unidos (LUNDESTAD, 1986, p. 263-264). Isso foi verificado nos casos da Europa, da Ásia e da América Latina - e do Brasil. Nesse contexto, é de se imaginar, primeiro, que o grau de liberdade dos que estão inseridos em um império é limitado; segundo, essa limitação é ainda maior quando se forma o império por convite (LUNDESTAD, 1986).

A terceira característica, finalmente, beneficia-se das anteriores e sintetiza a análise quanto ao grau de liberdade dos países ocidentais. Vale-se da tipologia elaborada por Hedley Bull (2002), pela qual a preponderância pode assumir três formas: dominância, hegemonia e primazia. Na dominância, há o emprego habitual da força pela grande potência contra os Estados menores no seu entorno geográfico, bem como o desrespeito mais que o habitual às regras do Direito Internacional (BULL, 2002, p. 244). Na hegemonia, o uso da força ou sua ameaça é ocasional e com relutância (BULL, 2002, p. 246). Na primazia, a preponderância, considerada justificada pelos outros membros, exerce-se sem o uso da força e sem maiores desrespeitos ao Direito Internacional (BULL, 2002, p. 245-246).

A partir dessas definições, Bull (2002, p. 246-248) informa que, durante a Guerra Fria, as relações dos Estados Unidos com a América Central e o Caribe foram caracterizadas pela hegemonia, enquanto com a Europa Ocidental, pela primazia. A relação dos Estados Unidos com a América do Sul foi caracterizada de maneira negativa por Bull (2002, p. 248): não foi de hegemonia. Pelo contexto, pode-se depreender, então, que, na América do Sul, os norteamericanos exerceram primazia.

Essa caracterização é coerente com os argumentos apresentados ao longo deste capítulo. Assim, reitera e ideia de que o Brasil esteve alinhado aos Estados Unidos na Guerra Fria. Registra, igualmente, a falta de possibilidades alternativas exequíveis a esse alinhamento, que se impunha até sobre as antigas potências europeias (relação de primazia). Por fim, endossa o argumento de que o Brasil - juntamente com a América do Sul, a Europa Ocidental e o Canadá - conservou sua autonomia decisória, uma vez que sua relação com os Estados Unidos não era nem de dominância, nem de hegemonia (BULL, 2002). 
Verifica-se, então, que a análise da arena internacional do pós-1945 endossa a precisão do modelo analítico elaborado por Hélio Jaguaribe (1976), segundo o qual a autonomia depende da presença cumulativa da viabilidade nacional e da permissibilidade internacional. Como não havia permissibilidade internacional, não existia possibilidade efetiva de adotar uma política externa plenamente autônoma. Em consequência, o alinhamento impôs-se.

Resta, no entanto, investigar o aspecto da viabilidade nacional (JAGUARIBE, 1976), ao que se dedicam as próximas seções. Nesse sentido, a análise que se segue será divida em duas partes, correspondentes às duas perspectivas da imposição: a positiva (exercício) e a negativa (resistência). Com isso, ter-se-á um quadro mais completo da "imposição do alinhamento" sobre a política externa do governo Dutra (1946-1950).

\subsection{Exercício do alinhamento}

O "clamor liberal" foi convertido em votos nas eleições de 1945. Afinal, houve uma clara inclinação do pêndulo político para o espectro ideológico mais liberal. Para afirmá-lo, está-se considerando que, entre as três agremiações políticas mais importantes na República Liberal-Conservadora, se verificava a seguinte ordem crescente quanto à adoção do liberalismo: PTB, PSD e UDN. É verdade que, dentro do PSD, havia um matiz variado de convicções ideológicas. De toda forma, conforme verificado pela análise do programa do partido, havia uma inclinação geral mais favorável que contrária em relação ao liberalismo, de modo que é legítimo situar o PSD em meio ao amplo espectro ideológico liberal.

Essa inclinação do pêndulo político para o espectro liberal é ilustrada pela análise da proporção obtida pelos partidos nas eleições de 1945 para o Senado Federal ${ }^{62}$ e para a Câmara dos Deputados $^{63}$ (tabela 2). Nesse sentido, o PSD e a UDN obtiveram, juntos, mais de $90 \%$ das cadeiras em disputa no Senado Federal e quase $82 \%$, na Câmara dos Deputados. A seu turno, o PTB alcançou participação de 4,8\% e 7,7\%, respectivamente.

\footnotetext{
62 TRIBUNAL SUPERIOR ELEITORAL. Dados estatísticos: eleições federal, estadual e municipal realizadas no Brasil a partir de 1945. v. 1. Rio de Janeiro: Departamento de Imprensa Nacional, 1950, p. 15.

${ }^{63}$ Ibidem, p. 20.
} 


\begin{tabular}{c|cc}
\multicolumn{3}{c}{ Quantidade de assentos obtidos por partido nas eleições de 1945-1 } \\
\hline PSD & Senado Federal & Câmara dos Deputados \\
UDN & $\mathbf{2 6}$ & $\mathbf{1 5 1}$ \\
PTB & $\mathbf{1 2}$ & $\mathbf{8 3}$ \\
PCB & $\mathbf{2}$ & $\mathbf{2 2}$ \\
PR & $\mathbf{1}$ & $\mathbf{1 4}$ \\
PPS & - & $\mathbf{7}$ \\
PDC & $\mathbf{1}$ & $\mathbf{4}$ \\
PL & - & $\mathbf{2}$ \\
& - & $\mathbf{1}$ \\
\multicolumn{2}{c|}{ Tabela 2. Elaborada pelo autor a partir de dados obtidos em TSE (1950). }
\end{tabular}

Naturalmente, tal configuração do Congresso Nacional, além de ser um indicativo do ambiente político do período, seria uma variável inescapável na arena político-partidária nacional entre 1946 e 1950. Assim, teria significativa influência sobre o tom da orientação política adotada pelo Poder Executivo nesses anos.

No âmbito do Poder Executivo, as eleições de dezembro de 1945 também repercutiram o "clamor liberal" do período. Afinal, saiu-se vencedor o candidato do PSD, o general Eurico Gaspar Dutra, que foi o único presidente eleito com mais de 50\% dos votos, em toda a República Liberal-Conservadora. Especificamente, Dutra obteve cerca de 55,4\% dos votos apurados -3.251 .507 de 5.870 .66764 .

Argumenta-se que a vitória de Dutra endossou o "clamor liberal", pois os resultados eleitorais são interpretados conjuntamente e em paralelo às medidas que se seguiram à instalação do novo governo. Assim, embora a candidatura do ex-ministro da Guerra também tenha sido apoiada pelo PTB, é possível depreender que a grande maioria dos votos foi obtida pelo PSD, partido mais próximo ao liberalismo que o PTB. Essa interpretação é apoiada pelos resultados das eleições legislativas de 1945, que consagraram o PSD, e não o PTB.

A esse cenário há de se acrescentar outros dois elementos relativos às eleições. Primeiro, a quantidade de votos obtidos pela UDN (brigadeiro Eduardo Gomes) na eleição presidencial - 2.039.341, o que equivalia a cerca de $34,7 \%{ }^{65}$. Segundo, a não desprezível participação dos udenistas tanto no Senado $(28,6 \%)$ quanto na Câmara $(29 \%)$.

\footnotetext{
${ }^{64}$ TRIBUNAL SUPERIOR ELEITORAL. Dados estatísticos: eleições federal, estadual e municipal realizadas no Brasil a partir de 1945. v. 1. Rio de Janeiro: Departamento de Imprensa Nacional, 1950, p. 11.

${ }^{65}$ Ibidem.
} 
A conjunção de todos esses elementos permite afirmar que o pêndulo da política brasileira pendeu para o espectro liberal após as eleições de 1945. Essa interpretação é confirmada pelas medidas que se seguiram ao pleito eleitoral. Sucintamente, podem-se citar o acordo interpartidário entre PSD e UDN (CHACON, 1998, p. 153), a Constituição liberaldemocrática de 1946 (FAUSTO, 2013, p. 109), a política econômica liberal (SKIDMORE, 1982, p. 96), o alinhamento internacional aos Estados Unidos (CERVO, 2008a, p. 47). Não à toa, Moniz Bandeira (2003, p. 235) refere-se ao governo Dutra como "um bloco de caráter liberal-conservador", reforçando a interpretação proposta nesta seção.

Além disso, era o próprio Eurico Dutra que se apresentava em oposição ao governo anterior - embora tenha recebido o apoio, ainda que relutante, de Getúlio Vargas nas eleições de 1945 (FAUSTO, 2013, p. 106). Isso é verificado, por exemplo, em sua Mensagem à Nação de 31/12/1946, ao registrar que 1946 foi um "ano de transição: na ordem interna, retomamos a nossa tradição secular de governo constitucional. [Na externa] mantivemos relações cordiais com todos os povos, e, em particular, com os nossos irmãos do Continente Americano. ${ }^{66}$

Analisados conjuntamente, esses elementos confirmam que Dutra não era continuador do governo Vargas, adotando orientação político-econômica diferente (DEVOTO; FAUSTO, 2004, p. 292). Ainda, constatam a força do "clamor liberal", que se traduziu em votos e medidas. É nesse contexto que, no âmbito da política externa, se manifestou (perspectiva positiva) a "imposição do alinhamento", conforme se passa a analisar.

\subsubsection{Os chanceleres de Dutra}

O PSD carregou, em si, esta contradição: embora, em muitos casos, se apresentasse em oposição ao governo anterior, o partido foi, quanto à origem de seus integrantes, uma vertente do getulismo (FAUSTO, 2013, p. 106). Nesse sentido, muitos dos membros do PSD haviam colaborado no governo Vargas. Disso é exemplo o próprio presidente Eurico Dutra, mas também vários outros personagens relevantes, como o primeiro chanceler na República Liberal-Conservadora, João Neves da Fontoura, cujo perfil é investigado na seção seguinte.

Optou-se por iniciar a análise da política externa brasileira pelo perfil dos chanceleres por duas razões. Primeira, a escolha desses perfis é testemunho do espírito do tempo. Afinal,

\footnotetext{
${ }^{66}$ Eurico Dutra, "Mensagem à Nação" (31 de dezembro de 1946).
} 
chanceleres são, normalmente, selecionados pela coerência entre os valores e os desafios do período, por um lado, e as características e as convicções do postulante, por outro. Segunda, esses perfis servem como regra geral da qual medidas específicas podem ser deduzidas. Regra geral, naturalmente, não significa relação causal necessária, mas sugere orientação plausível.

\subsubsection{João Neves da Fontoura}

O novo chanceler, do PSD, cultivava relação profunda e antiga com Vargas. Não à toa, antes de assumir a chefia do Itamaraty, João Neves consultou-se com Getúlio, pedindo-lhe "beneplácito e franco apoio" em carta de 12 dezembro de 1945. Uma semana após, em 19 de dezembro, Vargas manifestou "não só [...] apoio como [...] aplauso". Ambas as comunicações são, respectivamente, apresentadas a seguir:

Sei que o General Dutra deseja que eu faça parte do governo na pasta das Relações Exteriores. Isso comunicou ao Agamenon e ao Macedo, mas ainda nada me disse. Como bem deves compreender, meu ideal é ir de novo barra afora. [...] Não posso, entretanto servir ao governo dele senão com o teu beneplácito e franco apoio, empregando todos os esforços por uma cooperação proveitosa e leal entre ti e o Dutra. ${ }^{67}$

Tua entrada para o governo, como ministro das Relações Exteriores, tem não só meu apoio como meu aplauso. Quanto vieste de Portugal, pensei em convidar-te para essa função, não para fazer-te uma distinção, mas por sentir que teus serviços ser-me-iam necessários. É essa minha maior homenagem. Não levei avante meu propósito para não truncar tua carreira, estando eu já em fim de governo. ${ }^{6}$

Dessa forma, o presidente Dutra iniciou seu mandato com um chanceler deferente a Vargas, em cujo governo havia servido em diferentes funções, desde a Revolução de 1930. Essa nomeação, em consequência, poderia indicar a continuidade de uma lógica varguista na política externa brasileira. Isso, no entanto, não foi o que ocorreu.

No contexto do "clamor liberal", operou-se a "imposição do alinhamento" à política externa brasileira. Uma das formas para que isso ocorresse na gestão do novo chanceler foi a assimilação da ideologia liberal ao alinhamento com os Estados Unidos. Em termos bastante claros e diretos, foi o próprio João Neves da Fontoura que afirmou esse alinhamento, quando, na posse do presente Dutra, informou ao representante norte-americano: "o Brasil seguirá a política exterior dos Estados Unidos"69.

\footnotetext{
${ }^{67}$ CPDOC, GV c 1945.12.12/2.

${ }^{68}$ CPDOC, GV c 1945.12.19/1.

${ }^{69}$ La Guardia a Truman, 13.fev.46, HTL/OF (MOURA, 1996, p. 165).
} 
É bem verdade que, em alguma medida, o alinhamento ao país norte-americano já ocorria no governo Vargas, desde 1942, quando foi rompida a estratégia da equidistância pragmática (MOURA, 1980), que a diplomacia brasileira empreendia desde 1935. Por meio dessa estratégia, o Brasil havia-se colocado em equidistância entre as esferas de influência norte-americana (livre-cambismo, regime democrático) e alemã (comércio compensado, regime autoritário), com o objetivo pragmático de barganhar vantagens dos dois lados. $\mathrm{O}$ equilíbrio foi rompido com a cisão das relações diplomáticas do Brasil com o Eixo, em janeiro de 1942, e com a entrada brasileira na Segunda Guerra Mundial junto às forças Aliadas, em agosto do mesmo ano. Deu-se, então, a inserção do Brasil na esfera de influência norte-americana (BUENO; CERVO, 2012, p. 282).

A despeito disso, houve uma diferença fundamental entre os dois períodos, derivada, segundo a literatura (PINHEIRO, 2004), da natureza do americanismo que se verificou em ambos os momentos. No governo Vargas, Pinheiro (2004, p. 65) informa que ocorreu o americanismo pragmático, no qual a aliança com os Estados Unidos era percebida, fundamentalmente, como instrumental, com vistas a efetivar oportunidades. Já no governo Dutra, verificou-se, segundo Pinheiro (2004, p. 65), o americanismo ideológico, no qual a justificativa principal para a aliança com os norte-americanos seriam fatores de ordem normativa e convergência ideológica.

Alguns aspectos dessa distinção serão objeto de relativização no presente capítulo. De toda forma, a decomposição do americanismo em pragmático e ideológico (PINHEIRO, 2004) é uma análise sofisticada. Além disso, ela é útil para este trabalho, pois endossa-lhe dois argumentos. Primeiro, afirma que o governo Dutra não foi uma continuação do governo Vargas, uma vez que, por exemplo, a política externa foi modificada na chancelaria de João Neves da Fontoura. Segundo, corrobora a perspectiva positiva da "imposição do alinhamento", uma vez que essa mudança na política externa foi, justamente, o aprofundamento do americanismo. Em decorrência disso, com Dutra, o alinhamento aos Estados Unidos tornou-se mais intenso.

$\mathrm{Na}$ esteira desse segundo argumento, Silva (1995, p. 108) afirma que "João Neves da Fontoura pode ser considerado o típico representante do americanismo excessivamente ideológico". Prova desse alinhamento foi fornecida pelo próprio Fontoura em carta destinada a Oswaldo Aranha, em 12 de agosto de 1946, na qual comenta acerca das tratativas da 
Conferência de Paz de Paris: "meu entendimento com Byrnes [secretário de Estado norteamericano] sobre os múltiplos assuntos é completo"70.

Em dezembro de 1946, João Neves da Fontoura deixou a chefia do Itamaraty. Pediu demissão em protesto contra o acordo interpartidário que aproximava PSD e UDN (LOURENÇO NETO, 2012). O ex-chanceler, todavia, não se distanciou do Ministério. Ainda no governo Dutra, representou o Brasil na IX Conferência Internacional Americana, em 1948.

\subsubsection{Raul Fernandes}

Como exemplo concreto do acordo interpartidário, um prócer e fundador da UDN foi escolhido para chanceler. Típico representante udenista liberal e legalista, Raul Fernandes fora opositor ao Estado Novo. Registrou, contudo, que essa oposição era ao regime de exceção, e não pessoal contra Vargas ou seus seguidores (PECHMAN, 1984).

A substituição de João Neves proporcionou a Eurico Dutra duas vantagens. Primeira, a chefia do Itamaraty passou a ser ocupada por um diplomata com tradição ainda mais longa no Ministério das Relações Exteriores ${ }^{71}$. Segunda, Raul Fernandes representava um aliado inconteste, enquanto Fontoura "era por demais ligado a Vargas para se tornar um ministro de confiança de Dutra" (LOURENÇO NETO, 2012, p. 7).

A mudança de chanceler, no entanto, não alterou o perfil da diplomacia brasileira de maneira significativa. Ela, segundo Cervo (2008a), continuou orientada pelo alinhamento ideológico. Inclusive, para Lourenço Neto (2012), a assunção de Fernandes marcou o aprofundamento do alinhamento. Como manifestação desse alinhamento, Bueno e Cervo (2012, p. 293) apontam a política deliberada de Raul Fernandes de acompanhamento do voto dos Estados Unidos nas Nações Unidas. Outra manifestação foi o discurso do chanceler proferido em Montevidéu, em 16 de maio de 1947, no qual registra:

Por desígnio da Providência, o baluarte da civilização ocidental se deslocou da Europa para o continente americano, e dentro desse baluarte a força máxima se concentra na grande República do norte, propugnadora das liberdades humanas fundamentais sumuladas na declaração da independência americana e transplantadas na Carta do Atlântico e na de São Francisco. Esse

\footnotetext{
${ }^{70}$ CPDOC, OA cp 1946.08.12.

${ }^{71}$ Entre outros postos, Raul Fernandes foi plenipotenciário do Brasil junto à Conferência de Paz de Paris, de 1919; delegado nas Assembleias da Sociedade das Nações de 1919, 1920, 1921, 1924 e 1925; membro do Comitê de Juristas, de 1920, para elaboração do Estatuto da Corte Permanente de Justiça Internacional; consultor Jurídico do Corte Permanente de Justiça Internacional de Haia, em 1926; embaixador na Bélgica, em 1926; presidente da delegação brasileira na $6^{\mathrm{a}}$ Conferência das Repúblicas Americanas, em 1928 (PECHMAN, 1984).
} 
país é agora objeto de uma conspiração internacional de que posso falar abertamente, pois não constitui nenhum segredo, manifestada como é, todos os dias, pela imprensa, pelo rádio e por outros meios de difusão.

Creio, por isso, que é dever de todos os americanos cerrar fileiras dentro do continente em torno do irmão mais velho e mais forte. Ele assumiu nobres e graves responsabilidades na política mundial para a preservação da paz, da justiça e da liberdade; se não triunfarem estes ideais, e, com eles, a causa da democracia, a noite da civilização baixará sobre os homens. ${ }^{72}$

Esse discurso é bastante ilustrativo do pensamento de Raul Fernandes, bem como da manifestação (perspectiva positiva) da "imposição do alinhamento". Afinal, além de o alinhamento ser defendido francamente, foram-lhe expostas as justificativas ${ }^{73}$. Seriam, fundamentalmente, a existência de uma guerra ("conspiração internacional") contra os valores da liberdade e da democracia, bem como o papel protagônico dos Estados Unidos ("irmão mais velho e mais forte") na defesa desses valores.

Evidentemente, essa guerra a que Raul Fernandes se referia era o conflito bipolar que passava a moldar as relações internacionais na era das superpotências (WATSON, 1992). O discurso, dessa forma, exemplifica a preocupação com a Guerra Fria, o que foi uma constante durante a gestão de Fernandes à frente do Itamaraty (LOURENÇO NETO, 2014). Outro exemplo disso foi a carta enviada a Oswaldo Aranha em 29 de março de 1947 na qual afirmou: "nada aprendemos da guerra nem nos impressionamos com o conflito aberto entre o Ocidente e o Oriente. Esses erros, esse descuido do principal, vão levar-nos à perda da posição que conquistamos no Continente" 74 .

Com isso, verifica-se a incorporação de pressupostos ideológicos da Guerra Fria à prática discursiva dos chanceleres brasileiros durante a presidência Dutra (1946-1950). Entre esses pressupostos, destacam-se a segurança coletiva (CERVO, 2008a, p. 130), a "defesa da civilização cristã [...] e do mundo livre" (SILVA, 1995, p. 108), a luta contra o comunismo (FAUSTO, 2009, p. 402).

A mera incorporação desses pressupostos ao discurso diplomático já constitui manifestação (perspectiva positiva) da "imposição do alinhamento", mas, além disso, eles também se converteram em medidas concretas. Essas, como dito, compreendem, em algum

\footnotetext{
72 Alocução proferida em Montevidéu, em 16 de maio de 1947 (FERNANDES, 1967, p. 239).

73 Tanto a defesa do alinhamento quanto as justificativas para ele são encontradas em outros discursos do chanceler. Nesse sentido, acrescentam-se à lista, por exemplo, os discursos na $1^{\text {a }}$ Sessão Plenária da Conferência Interamericana de Manutenção da Paz e Segurança, em agosto de agosto de 1947; e no encerramento dessa Conferência, em setembro do mesmo ano (FERNANDES, 1967).
}

74 CPDOC, OA cp 1947.03.29. 
grau, derivações dos perfis apresentados. Essa ilação é ainda mais válida quando se considera que tanto os chanceleres quanto as medidas estão inseridos no mesmo contexto de "clamor liberal", analisado neste capítulo e no anterior. Considerando, assim, essa relação com a regra geral, passa-se a examinar as medidas específicas.

\subsubsection{Da regra geral para as medidas específicas}

Em relação às medidas específicas da afirmação do alinhamento, elas podem ser divididas, para fins didáticos e analíticos, em três grandes subgrupos. Nomeadamente, são eles: militar, econômico e político. Este, por sua vez, também comporta subdivisões, uma vez que o âmbito político pode ser analisado nas dimensões mundial e regional.

No âmbito militar, a associação do Brasil aos Estados Unidos pôde ser encontrada já em 1946, menos de um mês após a posse de Dutra como presidente. Tratou-se da compra de equipamentos e instalações de guerra norte-americanos que estavam em território brasileiro.

Argumenta-se que essa medida constituiu manifestação de alinhamento por duas razões. Primeira, ela confirmava a opção pelos Estados Unidos como fornecedor de produtos militares. Segunda, a venda desses produtos era percebida pelos norte-americanos como forma de consolidar sua influência política na região, por meio da padronização das forças armadas (HAINES, 1989). Nesse sentido, foi o próprio secretário de Estado James Byrnes, em telegrama ao embaixador norte-americano no Brasil Adolf Berle, que admitiu a disponibilização desse material "as a mesure in support of the principle of standardization"75.

Ainda em 1946, em agosto, houve a visita ao Brasil do chefe do Estado-Maior do Exército norte-americano Dwight Eisenhower. Em seu discurso no Congresso brasileiro, quando se reunia a Assembleia Constituinte, registrou: "I seek - as does the American Army to draw closer to you, so that my own individual efforts may be directed always by the certainty that a cooperative and undying friendship continues to exist between us"76. Verificam-se, assim, tanto a associação entre Brasil e Estados Unidos quanto a confirmação da análise de Svartman (2014a, p. 173) de que os norte-americanos procuraram cultivar os laços com os brasileiros também por meio de troca visitas de cortesia.

\footnotetext{
${ }^{75}$ FRUS, "832.24/1-446" (07 de fevereiro de 1946).

${ }^{76}$ Dwight Eisenhower. Diário da Assembleia, 9 de agosto de 1946.
} 
Outro meio, ainda no âmbito militar, foram as atividades de treinamento, assessoria e planejamento militar (SVARTMAN, 2014a) implementadas pelos Estados Unidos no Brasil. Nesse sentido, Moura (1991) registra a criação do Estado-Maior das Forças Armadas, a reorganização do Ministério da Guerra, a criação da Escola Superior de Guerra, iniciativas que seguiram os moldes norte-americanos.

Essa ascendência das forças armadas norte-americanas sobre a brasileira foi, inclusive, verbalizada pelo comandante da delegação dos Estados Unidos na Comissão Mista Militar Brasil-Estados Unidos. Em relatório, registrou em referência às escolas de Estado-Maior e de Moto-Mecanização e à Academia Militar: "estas instituições, antes fortemente influenciadas por doutrinas de outros exércitos, estão agora empreendendo, quase que exclusivamente, métodos e doutrinas dos Estados Unidos"77.

No âmbito econômico, o exercício do alinhamento aos Estados Unidos operou-se pela assimilação plena dos princípios liberais que passavam a orientar a nova ordem econômica ocidental, conforme analisado no primeiro capítulo. Essa assimilação foi ainda mais vigorosa no primeiro um ano e meio (1946-1947) do governo Dutra, quando sua política econômica foi manifestamente liberal (FERREIRA, 2012, p. 70).

Como visto, esse padrão de política econômica resultou do "clamor liberal", que, impulsionado por forças internas e externas, pressionava pela abertura da economia. Resultou, igualmente, de ponderações econômicas. Assim, além de alinhar as diretrizes governamentais tanto com a ideologia liberal predominante na gestão Dutra quanto com os compromissos internacionais (VIANNA, 2014, p. 108), a adoção do liberalismo econômico justificou-se por razões de natureza economicista - que serão apresentadas em seção posterior.

Efetivamente, houve, por exemplo, a instituição do mercado livre de divisas, uma vez que foram eliminadas as restrições, existentes desde a década de 1930, a pagamentos estrangeiros (VIANNA, 2014, p. 107). Promoveu-se, igualmente, abertura financeira e comercial - o que, neste caso, se traduziu em maiores facilidades para as importações.

Nesse contexto, a dependência econômica do Brasil aos Estados Unidos intensificouse, o que, certamente, constitui manifestação do alinhamento. Assim, os Estados Unidos país que mais se beneficiara da Segunda Guerra Mundial em termos econômicos, produzindo, no pós-guerra, quase metade da riqueza mundial - alcançaram participação aproximada de

${ }_{77}$ Monthly Report of Activities of the JBUSMC, 2 January, 1947, RG 333 Record of the international Military Agencies. JBUSMC, 1946-1952, box 7, NARA (SVARTMAN, 2014b, p. 95). 
58\% e 61\% nas importações feitas pelo Brasil em, respectivamente, 1946 e $1947^{78}$ (tabela 3). Igualmente, os Estados Unidos - praticamente o único país a ter abundância de divisas no pós-guerra - constituíam o mercado para, aproximadamente, $42 \%$ e $39 \%$ das exportações brasileiras em 1946 e $1947^{79}$, respectivamente (tabela 3).

\begin{tabular}{|c|c|c|c|c|}
\hline \multicolumn{5}{|c|}{ Comércio internacional do Brasil entre 1946 e 1947 (em milhões de dólares) } \\
\hline & $\begin{array}{l}\text { Importações } \\
\text { (totais) }\end{array}$ & $\begin{array}{c}\text { Importações } \\
\text { (dos Estados Unidos) }\end{array}$ & $\begin{array}{l}\text { Exportações } \\
\text { (totais) }\end{array}$ & $\begin{array}{c}\text { Exportações } \\
\text { (para Estados Unidos) }\end{array}$ \\
\hline 1946 & 671 & 391 & 939 & 396 \\
\hline 1947 & 1233 & 755 & 1146 & 449 \\
\hline
\end{tabular}

Ainda referindo-se ao liberalismo econômico do governo Dutra, dois outros grupos de medidas merecem menção. Primeiro, as importantes reformas administrativas que implicaram diminuição e desregulamentação do Estado, uma vez que foram fechados órgãos de atuação estatal na economia (SARETTA, 1995, p. 116). Segundo, a via ortodoxa de combate à inflação, na medida em que foram adotadas políticas fiscais e monetárias fortemente contracionistas (VIANNA, 2014, p. 107). Em conjunto, todas essas medidas confirmavam a incorporação do liberalismo - neste caso, na política econômica brasileira.

Por fim, o alinhamento aos Estados Unidos também foi verificado no âmbito político em suas duas dimensões, mundial e regional. No tocante à política mundial, o reconhecimento de governo e Estado foi um dos instrumentos utilizados pelo Brasil para demonstrar sua filiação ao bloco ocidental. Assim, por exemplo, em 1948, com a divisão da península coreana entre Sul e Norte, o Brasil reconheceu, apenas, a Coreia do Sul (GARCIA, 2005, p. 166), patrocinada pelos Estados Unidos. Situação similar foi verificada no caso da China. Afinal, com a Revolução Comunista de 1949, as relações diplomáticas com a China continental foram rompidas, e o Brasil não só não reconheceu a República Popular da China (RAMOS, 2006), como também fechou o consulado ${ }^{80}$ (BUENO; CERVO, 2012, p. 293).

Para além da comprovação da instrumentalização do reconhecimento de governo e Estado, o caso chinês foi significativo por dois outros motivos. O primeiro foi que a ruptura de relações diplomáticas com China continental demonstrou, claramente, o posicionamento

\footnotetext{
${ }^{78}$ Malan, 1995, p. 66.

${ }^{79}$ Ibidem, p. 66.

${ }^{80}$ Segundo o Direito Internacional, a ruptura de relações diplomáticas não implica necessariamente a ruptura das relações consulares (ACCIOLY; CASELLA; SILVA, 2012).
} 
do Brasil diante da guerra civil chinesa (1945-1949) - que punha em disputa nacionalistas e comunistas, forças que, durante a Segunda Guerra Mundial, estiveram unidas pelo esforço comum contra a ameaça japonesa (MORENO, 1995).

Por oportuno, registra-se que o apoio brasileiro às forças nacionalistas de Jiang Jieshi se manifestou antes mesmo desse rompimento, conforme demonstra a assinatura do Decreto Legislativo $\mathrm{n}^{\mathrm{o}} 8$ em 1948 (GOMES, 2016). Afinal, com essa medida, adotada em plena guerra civil chinesa, ratificava-se o Convênio Cultural firmado entre o Brasil e a República da China, em 1946, em cujo preâmbulo os dois países reconheciam "as vantagens que podem advir de uma maior aproximação espiritual" (SENADO FEDERAL, 1974, p. 128).

O segundo motivo, a seu turno, foi a demonstração, na prática, de dois princípios gerais que, segundo Moura (1990, p. 26), pautavam a atuação da delegação brasileira na ONU. Eles eram o acompanhamento da orientação norte-americana e a oposição às iniciativas soviéticas ou de seus satélites (MOURA, 1990, p. 26). Nesse sentido, quando foi colocada a questão do ingresso da República Popular da China na ONU, o Brasil seguiu o voto norteamericano, que se opôs a essa possibilidade (BUENO; CERVO, 2012, p. 272-273).

No tocante à política regional, muitas das medidas que ilustram a afirmação do alinhamento brasileiro à esfera de influência norte-americana já foram analisadas. Esse é o caso, por exemplo, do TIAR, que implicou a incorporação do Brasil ao sistema de segurança coletiva regional (LIGIÉRIO, 2011); e da OEA, que institucionalizou o sistema interamericano e, consequentemente, consolidou o poder dos Estados Unidos no continente (PINHEIRO, 2013, p. 162).

Em relação a este país, além do que já foi registrado, ainda merece menção a troca de visitas entre os dois presidentes. Especificamente, em 1947, Harry Truman veio ao Brasil e, em 1949, Eurico Dutra foi aos Estados Unidos. Neste caso, inclusive, tratou-se da primeira visita oficial de um chefe de Estado brasileiro aos Estados Unidos (GARCIA, 2005, p. 167), o que é bastante ilustrativo do alinhamento verificado no período.

Ainda em referência ao âmbito político regional, há, por fim, a Argentina. Nesse caso, a emergência da Guerra Fria levou ao gradativo abandono da orientação cooperativa, em vigor entre 1930 e 1945, entre a Casa Rosada e o Catete (CERVO, 2007). Afinal, as posições de Dutra e Perón eram antagônicas em quase tudo, como na relação com os Estados Unidos (PINHEIRO, 2013, p. 163). 
O alinhamento aos Estados Unidos e o antagonismo com a Argentina são ilustrados, pelo telegrama enviado pelo chanceler João Neves ao embaixador em Buenos Aires Batista Luzardo. Em relação ao alinhamento, lê-se: "nunca devemos perder de vista - e o Presidente Dutra e eu nunca o perdemos - que a nossa política é feita diretamente em harmonia com os Estados Unidos, em cujo lado lutamos nesta última guerra"81. Quanto ao antagonismo: "somos pela unidade continental e por um tratamento fraterno entre todas as Repúblicas, mas é preciso que todas deem mostras de lealdade, de espírito de cooperação, de compreensão dos deveres recíprocos. Ora, Perón não está correspondendo a nenhum desses imperativos".

Com essa mensagem, visualiza-se, limpidamente, a percepção do Brasil de Dutra acerca da Argentina de Perón e como isso interagia na relação com os Estados Unidos. Assim, verificam-se a desconfiança do Brasil quanto aos argentinos e a orientação brasileira ante a política continental. Na essência dessa relação triangular, destacou-se o alinhamento da política externa do governo Dutra aos Estados Unidos.

\subsection{Resistência ao alinhamento}

Após a análise da perspectiva positiva (exercício) da "imposição do alinhamento", procede-se à investigação de sua perspectiva negativa (resistência). Com isso, procura-se demonstrar não apenas que houve o alinhamento da política externa de Dutra aos Estados Unidos, mas também que essa era a única opção viável. Por isso, o alinhamento impôs-se.

A reflexão acerca da perspectiva negativa será empreendida em duas etapas, devido à necessidade de apor ressalvas à interpretação tradicional, composta por três aspectos, da política externa brasileira do pós-1945. O primeiro aspecto refere-se ao relativo consenso quanto à definição do governo Dutra como alinhado aos Estados Unidos (CERVO, 2008; DORATIOTO; VIDIGAL, 2014; MOURA, 1990; SCHWARCZ; STARLING, 2015; SILVA, 1995). Esse aspecto foi endossado pela seção anterior, na qual se analisaram episódios em que o alinhamento foi exercitado. Assim, restam dois outros aspectos - que se associam às duas etapas da análise a ser desenvolvidas nesta seção.

A primeira etapa visa a abordar o segundo aspecto da caracterização tradicional da política externa do general Dutra: a tendência de se analisá-la retrospectivamente. Tal

\footnotetext{
${ }^{81}$ João Neves da Fontoura a João Batista Luzardo, telegrama, Rio de Janeiro, 15 jun. 1946, AHMRE-B, 600(41),
} Cx. 216, Maços Temáticos Secretos. 
tendência já começou a ser questionada no capítulo anterior, no qual foi investigado o "clamor liberal" que se impunha ao Brasil do pós-1945. Assim, com o foco nos elementos postos à época, verificou-se que havia fatores internos e externos que tornavam o liberalismo uma força praticamente inescapável ao governo que se seguiria ao Estado Novo.

Nesta seção, dar-se-á continuidade a esse questionamento. Duas "ilusões" da governo Dutra (CERVO, 2008a, p. 130) serão abordadas: a "ilusão" quanto à expectativa de que o Brasil teria "relações especiais" com os Estados Unidos no pós-guerra e a "ilusão" quanto à política econômica liberal. Essa primeira etapa é uma espécie de introdução para a análise da vertente negativa da imposição. Afinal, o fornecimento de justificativas para essas "ilusões" permite empreender a investigação da resistência ao alinhamento a partir de uma discussão mais avançada, deixando para trás o debate quanto à liberalidade e à falta de propósito e autonomia decisória das políticas interna e externa do governo Dutra.

A segunda etapa, por fim, analisa manifestações de resistência ao alinhamento. Assim, visa a enfrentar o terceiro aspecto da caracterização tradicional da política externa do general Dutra: a tendência de as análises quanto a esse governo aterem-se à perspectiva positiva da imposição. Com isso, objetiva-se complementar essas análises por meio da incorporação da vertente negativa (resistência ao alinhamento) da imposição.

\subsubsection{A racionalidade do alinhamento}

A análise retrospectiva é uma das principais vantagens do analista das relações internacionais diante do tomador de decisão, que, pelo cargo, é impelido a elaborar análises prospectivas. Isso, muitas vezes, justifica interpretações diferentes para os mesmos fatos.

No caso do governo Dutra, essa diferença temporal levou a uma cisão profunda. Do lado do tomador de decisão, implementou-se uma política externa e econômica com elevado grau de alinhamento aos Estados Unidos; do lado dos analistas, há a condenação igualmente intensa dessa "opção"82. Estes, então, ressaltam as "ilusões" políticas e econômicas dessa gestão, como se as medidas implementadas tivessem sido exercícios de liberalidade.

Há, todavia, literatura (ALTEMANI, 2005; BASTOS, 2004; DORATIOTO; VIDIGAL 2014; PINHEIRO, 2004; SARETTA, 1995; VIANNA, 2014) que incorpora os elementos

82 Já se viu que é impreciso falar em "opção", uma vez que não havia alternativas viáveis à época, o que é, comumente, ignorado pelos críticos das políticas interna e externa do governo Dutra. 
postos à época, explicitando a racionalidade das políticas de Dutra, sem, com isso, deixar de registrar que os resultados esperados pelo governo não se concretizaram. É com o objetivo de se juntar a essa literatura que se propõe a analisar, nas próximas duas subseções, justificativas para o alinhamento externo aos Estados Unidos e para o liberalismo econômico.

\subsubsection{A "ilusão" política}

Em relação à expectativa brasileira quanto à manutenção de "relações especiais" com os Estados Unidos, Doratioto e Vidigal (2014, p. 67) caracterizam-na de maneira precisa como uma convicção válida, mas que se relevaria equivocada. Assim, pela análise retrospectiva, torna-se evidente que essa expectativa foi frustrada, mas, na época, havia elementos que endossavam essa esperança.

Segundo Bueno e Cervo (2012, p. 290), essa expectativa era alimentada pelo fato de o Brasil ter tido participação militar junto às forças Aliadas na Segunda Guerra Mundial, pela redemocratização das instituições nacionais e pela intercessão brasileira em favor dos Estados Unidos na política latino-americana. Desses elementos, o que mais se destacava era o envio de tropas para a guerra, especialmente pelo fato de o Brasil ter sido único país da América Latina a fazê-lo (PINHEIRO, 2013, p. 160).

A expectativa de "relações especiais" fundava-se, ainda, em outro elemento: os Estados Unidos, cujas autoridades identificavam e alimentavam essa expectativa. Em 1946, por exemplo, quando se colocava o levantamento não seletivo da Proclaimed List of Blocked Nationals ${ }^{83}$, o encarregado de negócios Daniels ponderou ao secretário de Estado Byrnes:

Simultaneous withdrawal on world-wide basis would (1) constitute failure to recognize the effective cooperation Brazil has given us throughout the war and the far-reaching measures she has adopted to eliminate Axis influence within her borders; (2) place Brazil in the same category with certain countries such as Spain and Sweden which worked with the enemy throughout the conflict. There is every reason to believe that such treatment of Brazil would be most disillusioning to the many official Brazilians who did their utmost to stamp out Axis activities and influence. ${ }^{84}$

Nesse sentido, na época, não era uma "ilusão" considerar a continuidade desse relacionamento especial, que rendera ao Brasil volumosos investimentos durante a Segunda

\footnotetext{
${ }^{83}$ Instituída em julho de 1941 e extinta em julho de 1946, a Proclaimed List of Blocked Nationals, popularmente conhecida como "Lista Negra", visava a bloquear, em nome da defesa nacional, ativos de indivíduos e empresas relacionados aos países do Eixo (QUINTANEIRO, 2005, p. 79).
}

${ }^{84}$ FRUS, "Telegrama 740.32112A/5-846" (8 de maio de 1946). 
Guerra Mundial e que lhe cortejara um assento permanente no Conselho de Segurança das Nações Unidos (GARCIA, 2011). Havia, sim, elementos para se acreditar nisso.

\subsubsection{A "ilusão" econômica}

Para Visentini (2013b, p. 200), "à subserviência político-diplomática somou-se a econômica". O que se depreende dessa caracterização do governo Dutra é que as medidas econômicas desse período não teriam sido adotadas de modo a contemplar os interesses do Brasil. Elas, por serem subservientes, teriam sido implementadas para servir "às vontades de outrem"85 - no caso, dos Estados Unidos.

Essa interpretação, todavia, é inconsistente, pois desconsidera que a implementação do liberalismo econômico no pós-1945 resultou, além do "clamor liberal", de ponderações econômicas. Eram, especificamente, quatro razões principais, todas de cunho economicista.

Primeira, segundo Vianna (2014, p. 107), esperava-se, primeiramente, que a economia mundial se recuperaria rapidamente que seriam adotados os princípios liberais de Bretton Woods. Nesse caso, se a economia mundial retomasse seu vigor e houvesse liberdade de movimentação de divisas e mercadorias, aumentariam tanto a demanda pelos produtos importados do Brasil quanto os investimentos externos diretos no país.

Segunda, havia a expectativa de alta acentuada dos preços do café, pois, em julho de 1946, os Estados Unidos eliminaram-lhe o preço-teto. Isso, certamente, alimentava otimismo quanto ao setor externo. Afinal, em 1946, o café correspondia a 35\% das exportações brasileiras - nomeadamente, Cr\$ 6.441,46 milhões ${ }^{86}$ de Cr\$18.230,00 milhões ${ }^{87}$.

Terceira, a combinação entre estabilidade cambial - que era "princípio sacrossanto" dos acordos de Bretton Woods (ALMEIDA, 1996, p. 185) -, cruzeiro valorizado e maior liberdade de circulação de mercadorias visava a suprir a demanda tanto de matérias-primas quanto de bens de capital (VIANNA, 2014, p. 107). Assim, conforme observa Bastos (2004, p. 116), essa combinação objetivava estimular e modernizar a indústria nacional.

\footnotetext{
${ }^{85}$ Segundo definição encontrada em Houaiss e Villar (2001, p. 2628), subserviente significa: "1: consente em servir a outro de maneira humilhante; que se presta às vontades de outrem servilmente; servil; 2: condescendente em demasia; que atende às vontades alheias com demasia".

${ }^{86}$ IBGE, 1987, p. 312.

${ }^{87}$ Ibidem, p. 525.
} 
Isso, inclusive, foi o próprio Dutra que disse na Mensagem ao Congresso Nacional em 1947. Assim, para combater o desequilíbrio econômico-financeiro, o governo recorreria a "medidas de duas espécies: umas, de natureza financeira, para estancar a corrente emissiva avolumadora do meio circulante; outras, de natureza econômica, com o objetivo de aumentar a produção interna e, subsidiariamente, a importação dos artigos de maior carência"88. O governo, nesse contexto, deveria priorizar "a melhoria econômica da produção", de modo a "intensificar, direta ou indiretamente, os empreendimento que visem à entrega dos produtos mais reclamados pelos consumidores". Ainda, em relação ao "revigoramento da economia nacional", dever-se-ia proceder ao "equipamento industrial das atividades de base, incluindo energia elétrica, indústrias carbonífera e petrolífera, grande indústria química e mecânica e metalurgia de metais leves".

Esses excertos da Mensagem ao Congresso Nacional de 1947 oferecem outro benefício analítico, além de confirmar que o liberalismo econômico não era subserviente, mas atendia a interesses nacionais. Trata-se da refutação de outro argumento comumente utilizado para qualificar o governo Dutra como entreguista (VISENTINI, 2013b). Afinal, um dos pilares dessa qualificação é que a política econômica do imediato pós-1945 teria sido antiindustrialista, objetivando o retorno à suposta vocação agrícola do Brasil (MOURA, 2012; SKIDMORE, 1982; VISENTINI, 2013b).

Como demonstrado, no entanto, esse não era o objetivo da política econômica de Dutra (BASTOS, 2012; SARETTA, 1995; VIANNA, 2014). Não à toa, ao longo desse período, o PIB industrial apresentou taxa média de crescimento anual superior ao agrícola, respectivamente: 11,4\% e 4,4\% (ABREU, 2013, p. 205).

Nos mesmos excertos, é possível encontrar a quarta e última razão para a política econômica liberal do governo Dutra: o combate à inflação, traduzido em "estancar a corrente emissiva avolumadora do meio circulante". Afinal, a partir de 1941, a inflação acelerou, passando de 6,7\% em 1940 para 20,6\% em 194489. Assim, cruzeiro valorizado e maior liberdade de circulação de mercadorias atuariam como "âncora cambial" (GREMAUD; VASCONCELLOS; TONETO JÚNIOR, 2010, p. 452).

\footnotetext{
${ }^{88}$ Eurico Dutra, "Mensagem ao Congresso Nacional" (15 de março de 1947), p. 57-60.

89 Valores apresentados por Abreu (2014, p. 409) para o "deflator implícito do PIB", que é a principal forma de medir a variação de preços (GREMAUD; VASCONCELLOS; TONETO JÚNIOR, 2010, p. 47).
} 


\subsubsection{A resistência na prática}

Ao longo deste capítulo, desenvolveu-se o quadro conceitual da resistência ao alinhamento - perspectiva negativa da imposição. Resta, então, analisar como esse quadro conceitual se manifestou na prática, ao que se dedica esta seção.

Nesse sentido, serão analisadas medidas nos âmbitos político e econômico. Isso permite que se conclua, ao final, que a resistência não foi um erro estatístico, mas um componente integrante das política interna e externa do Brasil nesse período. Afinal, foi verificada em medidas de natureza diversa.

\subsubsection{No âmbito político}

Para ilustrar a resistência ao alinhamento no âmbito político, analisa-se o rompimento das relações diplomáticas com a União Soviética. Argumenta-se que essa associação é possível, pois a ruptura com os soviéticos decorreu, essencialmente, de considerações domésticas (GOMES, no prelo). Mais ainda, ela ocorreu a despeito da posição dos Estados Unidos, que, não só não romperam relações diplomáticas com a União Soviética, como também tentaram demover o Brasil de fazê-lo (HILTON, 1994, p. 451-452).

Assim, partilha-se do parecer de Ricupero (1995, p. 43) de que "longe de corresponder aos estímulos das potências ocidentais", a ruptura com a União Soviética foi "expressiva de um anticomunismo autóctone". Não se pode, então, afirmar que essa ruptura atendia a interesse de outrem. Ao contrário, correspondia a um sentimento profunda e longamente assentado na sociedade brasileira (MOTTA, 2007; MENDES, 2012). Não à toa, o Brasil não reconheceu o governo comunista após a Revolução Russa, de 1917 (GARCIA, 2005, p. 128), só vindo a fazê-lo em 1945 e, ainda assim, por um curto espaço de tempo.

No governo Dutra, esse arraigado anticomunismo materializou-se em uma série de medidas, como o Decreto-Lei $\mathrm{n}^{\circ}$ 9.258, de 1946, cujo artigo 26 permita o cancelamento do registro de partido político em razão tanto de orientação político-partidária estrangeira quanto da ofensa aos princípios democráticos (BRASIL, 1946). Ainda foram exemplos o fechamento, em 1947, da Juventude Comunista e o cancelamento, em 1947, do registro do Partido Comunista do Brasil (PCB) pelo Superior Tribunal Eleitoral (REZENDE, 2006). 
Nesse contexto, não surpreende a ruptura de relações diplomáticas com a União Soviética, efetivada em 20 outubro de 1947 (GARCIA, 2005, p. 164). Tampouco surpreendem o apoio popular e o parlamentar a essa medida, conforme se verifica, respectivamente, em duas matérias do jornal Folha da Manhã, publicadas em 22 de outubro de 1947:

Desde que foram conhecidos os termos da nota da representação brasileira ao governo da URSS, numerosos grupos populares manifestaram o seu apoio à atitude das nossas autoridades. Comícios foram improvisados. Vários oradores analisaram a nossa posição no panorama internacional e repetiram todos os insultos que foram dirigidos contra o chefe do governo [pelo jornal soviético Gazeta Literária] e o Executivo nacional. A primeira manifestação contra a Rússia verificou-se defronte à embaixada da URSS [...]. Algumas pessoas exaltadas para ali se dirigiram, arrancaram a placa de metal colocada à porta e pretenderam alcançar os jardins da embaixada, pulando pelas grades. ${ }^{90}$

Às $18 \mathrm{~h} 30$ de hoje foi recebida em audiência especial, pelo presidente da República, uma comissão de representantes da Câmara dos Deputados. [...] Esses deputados, pertencentes a diferentes agremiações partidárias, [...] manifestaram a sua excelência o apoio incondicional de seus pares, que veem, na determinação do governo, um gesto desassobrado ditado pelo poder nacional ofendido pelas injúrias assacadas contra nossas instituições, nosso povo e nosso primeiro magistrado por publicações soviéticas. ${ }^{91}$

Essas manifestações são coerentes com o argumento de que a ruptura foi tomada em consonância com os valores da sociedade brasileira. Em sentido contrário, elas atestam que a cisão com os soviéticos não visava a atender interesses de outrem.

Isso fica ainda mais evidente quanto se verifica que os Estados Unidos, o principal terceiro envolvido, além de não terem qualquer participação nessa ruptura, explicitaram ao Itamaraty que seguiriam posição distinta. É o que se constata em telegrama do encarregado de negócios David Key ao secretário de Estado em exercício Robert Lovett no qual relata diálogo com o chanceler Raul Fernandes: "I took occasion to inquire whether there was any truth to rumors which have appeared in local press that Brazil may soon break relations with Russia. [...] He realized, of course, that our position was different"192. Key, inclusive, ponderou para Fernandes que, em situação similar, os Estados Unidos não tomaram nenhuma medida drástica [leia-se, ruptura] "following Molotov's rebuff to our protest against similarly venomous Soviet press articles about President Truman recently".

Além do mais, se, incialmente, os norte-americanos se abstiveram quanto a essa questão - "this [a ruptura entre Brasil e União Soviética] is a matter which only Brazil can

${ }^{90}$ FOLHA DE SÃO PAULO. Repercussão do rompimento das relações diplomáticas entre o Brasil e a Rússia. Folha da Manhã. São Paulo, p. 3, 22 out. 1947.

${ }^{91}$ FOLHA DA MANHÃ. Solidariedade de deputados ao presidente da República. Folha da Manhã. São Paulo, p. 3, 22 out. 1947.

${ }^{92}$ FRUS, "Telegrama 732.61/10-947" (9 de outubro de 1947). 
decide" ${ }^{\prime \prime 3}$, respondeu Lovett a Key -; posteriormente, eles intervieram para evitar a ruptura. Assim autuaram, por exemplo, o secretário de Estado George Marshall junto à delegação brasileira na $\mathrm{ONU}^{94}$ e um diplomata norte-americano no Rio de Janeiro junto ao Itamaraty95.

\subsubsection{No âmbito econômico}

A política econômica do governo Dutra é comumente utilizada como atestado do alinhamento brasileiro aos Estados Unidos. Essa interpretação, inclusive, foi exposta neste capítulo, quando se analisou a vertente positiva da imposição. Apesar disso, a mesma política também pode ser utilizada com fins opostos. Assim, as medidas econômicas adotadas no pós-1945 permitem, igualmente, demonstrar a resistência àquele alinhamento.

Dessa forma, a vertente negativa da imposição pode ser exemplificada pelos controles sobre o câmbio e sobre as importações que começaram a ser adotados a partir de julho de 1947 (VIANNA, 2014, p. 110). O mesmo significado é depreendido de outras medida. Assim, a partir de fevereiro de 1948, começou a ser montado um sistema de contigenciamento de importações sob o regime de licenças prévias, concedidas segundo critérios de essencialidade e similar nacional (VIANNA, 2014. p. 110-114). Sistema esse que vigoraria, legalmente, até 1953, quando foi revogado pela Instrução 70 da SUMOC (ABREU, 2013, p. 209).

Essas medidas, naturalmente, não estavam inspiradas no liberalismo norte-americano, conforme analisado no capítulo anterior. Nesse sentido, basta lembrar os princípios da Carta do Atlântico, de 1942, segundo os quais os controles à livre movimentação de mercadorias deveriam ser eliminados. Dessa forma, políticas econômicas adotadas no governo Dutra estavam em franco desacordo com o que os Estados Unidos prescreviam.

A mesma conclusão aplica-se ao debate quanto à exploração dos recursos minerais brasileiros, em que o petróleo tinha especial destaque. Nesse sentido, o Departamento de Estado norte-americano e o Foreign Office britânico atuaram de maneira bastante ativa e consistente junto ao governo e ao Congresso brasileiros (MOURA, 2012, p. 217). O objetivo era garantir ao capital estrangeiro o acesso àqueles recursos.

\footnotetext{
${ }^{93}$ FRUS, "Telegrama 501.BB/10-947" (11 de outubro de 1947).

${ }^{94}$ Aranha a MRE, 18/10/47 (teleg. 231), AHI (HILTON, 1994, p. 451-452).

95 Memorando de Keeler, NA/RG 59 732.61/10-2847 (MOURA, 2012, p. 237)
} 
Quanto ao tema, a Constituição brasileira aprovada em 1946 prescreveu, no artigo 153, que "o aproveitamento dos recursos minerais e de energia hidráulica depende de autorização ou concessão federal na forma da lei"96. Por sua vez, o parágrafo primeiro desse artigo estabeleceu que "as autorizações ou concessões serão conferidas exclusivamente a brasileiros ou a sociedades organizadas no País".

A partir desses dispositivos legais, é possível depreender duas conclusões. Primeira, ainda que o capital estrangeiro fosse permitido formalmente, ele deveria, no mínimo, ser nacionalizado - "ou sociedades organizadas no País". Segunda, havia duas limitações cumulativas à exploração dos recursos minerais: por um lado, "a autorização ou concessão federal"; por outro, a lei que viria a regulamentar esse aproveitamento, "na forma da lei".

Os debates em torno dessa lei foram intensos e puseram em conflito interesses e grupos diversos. Especificamente, as grandes companhias estrangeiras de petróleo - e seus governos - saíram derrotadas, uma vez que não foi aprovada legislação que atendesse a seus interesses (MOURA, 2012, p. 217-218). Ainda em 1948, esse contexto e seu resultado já eram claros para a diplomacia norte-americana, conforme se verifica no seguinte memorando:

Controversy with reference to the law exists throughout Brazil. Certain interests wish to make the petroleum industry in Brazil a government monopoly, other interests wish to open it to private capital with Brazilian capital in control, yet permitting foreign capital to participate with a minority interest, and a few people openly advocate opening up the country to foreign capital, with certain safeguards. So far advocates of the last course are greatly in the minority. [...] It is well known that the spirit of nationalism is very strong in Brazil.

[...] The Army is steeped in nationalism.

[...] The industrialists do not want United States capital to dominate and control petroleum development or refining in Brazil.

[...] The Communists created and led the attack against American capital in the development of Brazil. Through an extremely able and clever use of the press and by influencing the young people in schools and colleges they have made the opposition to foreign capital appear to be of a spontaneous origin, rather than of Communistic origin. They developed the slogan "Brazilian oil for Brazilians" which appears all over Brazil in the press and on posters. ${ }^{97}$

Em conjunto, essas medidas demonstram que, quando necessário, o Brasil exercitou sua resistência, ainda que limitada, ao alinhamento aos Estados Unidos. Afinal, este país assistiu à oposição tanto à sua ideologia liberal quanto aos seus interesses materiais. Nada mais distante do suposto alinhamento incondicional e subserviente pelo Brasil.

Ao contrário, pode-se mesmo encontrar nessa política econômica do governo Dutra traços do que o internacionalista argentino Juan Carlos Puig conceituou como autonomia

\footnotetext{
${ }^{96}$ Artigo 153, Constituição dos Estados Unidos do Brasil de 1946.

${ }^{97}$ FRUS, "832.6363/8-1948" (19 de agosto de 1948).
} 
heterodoxa (RUIZ, 2015). Afinal, sua política econômica apresentou duas características desse conceito. Por um lado, o Brasil aceitou a liderança da potência dominante. Por outro, o modelo de desenvolvimento interno ensaiado por aquelas medidas não coincidiu com as expectativas e as preferências do poder hegemônico, os Estados Unidos (RUIZ, 2015, p. 37).

\subsection{Conclusões parciais}

Neste capítulo, analisou-se a "imposição do alinhamento" à política externa do governo Dutra. Foram desenvolvidas e investigadas suas vertentes positiva (exercício) e negativa (resistência). Assim, demonstrou-se que o alinhamento ocorreu a despeito de medidas que lhe desafiavam. A política alinhada impôs-se.

Na literatura, o padrão de inserção internacional do Brasil de Dutra é apresentado como inusitado, excepcional, destoante, um passo fora da cadência (BUENO; CERVO, 2012, p. 394; CERVO, 2008a, p. 46). Essa interpretação, todavia, só subsiste se empreendida por meio de lentes diacrônicas - em outros termos, se efetivada em relação a variáveis, fatores, condutas, referências de outros períodos históricos.

Afinal, caso se analise a política externa do governo Dutra segundo os elementos nacionais e internacionais que se punham à época, é fácil constatar que o alinhamento era "natural", esperado, coerente. Inclusive, era a única "opção" efetivamente viável.

A investigação quanto ao contexto internacional demonstrou que, no pós-1945, se consolidou o império americano (LUNDESTAD, 1986) no Ocidente. Mais, demonstrou que a esse império, formado por convite (LUNDESTAD, 1986), ficaram submetidas até as antigas potências da Europa, que eram hegemônicas durante a sociedade internacional europeia (WATSON, 1992). Nesse contexto, será que o Brasil poderia escapar ao alinhamento? Naturalmente, que não. Por isso, a política alinhada foi o resultado lógico do período. No contexto em que se manifestou, não houve nada de exótico no alinhamento. Afinal, não havia permissibilidade internacional, segundo a tipologia elaborada por Jaguaribe (1976).

Afirmar que a política externa alinhada era "natural", "lógica" não significa, no entanto, o mesmo que caracterizá-la como entreguista e subserviente (VISENTINI, 2013b) ou como desprovida de autonomia decisória (CERVO, 2008a). Ao contrário, o alinhamento atendia aos interesses nacionais. Não à toa, Bull (2002) interpreta a inserção da América do 
Sul (e do Brasil, consequentemente) na esfera de influência norte-americana como uma relação de primazia - mesma categoria aplicada à relação norte-americana com a Europa Ocidental -, e não como relação de dominância ou de hegemonia.

Dessa forma, o alinhamento tinha uma racionalidade, amparada em interesses políticos e materiais. A não concretização desses interesses na magnitude esperada resultou em interpretações de que o Brasil padecia de "ilusões". Ressalta-se, no entanto, que, no período, essas "ilusões" eram bastante concretas, plausíveis. Por isso, as aspas apostas ao substantivo ilusões, pois, na época, as expectativas do governo Dutra não eram ilusões, apenas posteriormente se transformaram em ilusões.

Além disso, o argumento de que o Brasil de Dutra foi entreguista e subserviente (VISENTINI, 2013b), bem como desprovido de autonomia decisória (CERVO, 2008a) revelase de difícil sustentação quando se verifica que, durante esse período, o país apresentou taxa média de crescimento econômico anual de 7,6\% (GONÇALVES, 2016, p. 8). Em termos comparativos, no governo do presidente Vargas, considerado a antítese autonomista de Dutra, a mesma taxa foi de 4,3\% entre 1930-1945 e 6,2\% entre 1951-1954 (GONÇALVES, 2016, p. 8). Assim, no governo autonomista de Vargas, cresceu-se à taxas bem inferiores às verificadas no governo entreguista e subserviente (VISENTINI, 2013b) e desprovido de autonomia decisória (CERVO, 2008a).

Ainda, no setor industrial, verificou-se crescimento médio anual de $11,4 \%$ durante o governo Dutra, enquanto, no agrícola, foi de 4,4\% (ABREU, 2013, p. 205). Apresenta-se o desempenho da indústria, pois, muitas vezes, o estímulo ao desenvolvimento industrial é apresentado como sinônimo de política autonomista. Nessa linha, o governo Dutra é apresentado como entreguista por, entre outras coisa, ter sido anti-industrialista (BASTOS, 2004). Como visto, essa interpretação não tem amparo nos dados.

Dessa forma, o acelerado crescimento econômico, de maneira geral, e industrial, de maneira específica, demonstra que caracterizar as políticas adotadas por Eurico Dutra sem considerá-las como instrumentais é uma imprecisão. Em consequência, a divisão estrita entre americanismo pragmático e americanismo ideológico (PINHEIRO, 2004), apesar de fundada sobre uma análise sofisticada, apresenta limites. Afinal, mesmo o americanismo de Dutra, caracterizado como ideológico, também era instrumental, visando à consecução de oportunidades, predicativos associados ao americanismo pragmático. 
Assim, a adoção da ideologia liberal - e a "opção" pelo alinhamento - não foi uma liberalidade nem uma atitude subserviente. Ao contrário, representou uma via para o desenvolvimento nacional. Tanto é assim que, quando julgado necessário, o Brasil adotou políticas que contrariaram (vertente negativa da imposição) o liberalismo político-econômico, o alinhamento aos Estados Unidos.

A "imposição do alinhamento" durante o governo Dutra não significou, portanto, a renúncia aos interesses nacionais. Embora imposta por fatores externos e internos, a política alinhada visava, naturalmente, ao desenvolvimento do país por meio dos instrumentos considerados adequados pelo processo decisório brasileiro. 
Capítulo III

\section{Imposição do alinhamento: o governo Vargas}

Neste capítulo, procede-se à investigação da política externa do segundo governo Vargas (1951-1954) - doravante, "governo Vargas" - sob a lente da "imposição do alinhamento". Para tanto, dar-se-á continuidade à análise pelas perspectivas negativa e positiva da imposição. Assim, serão pesquisados episódios que confirmem o alinhamento aos Estados Unidos e episódios que se oponham a ele, ressaltando que adesão (perspetiva positiva) e resistência (perspectiva negativa) podem ocorrer em graus variados.

A confirmação de que o alinhamento também teria se imposto durante a gestão varguista trará dois ganhos analíticos relevantes para este trabalho. O primeiro é o endosso da hipótese levantada nos capítulos anteriores de que o "clamor liberal" impulsionado por forças internacionais e nacionais se impôs sobre as políticas interna e externa do Brasil do pós-1945. Assim, haveria a "imposição do alinhamento" independentemente do presidente que viesse assumir o Catete em 1946. Isso permite atenuar o peso da crítica quanto ao alinhamento verificado na política externa de Dutra.

Com isso, sem negar que houve alinhamento, pode-se reconhecer que essa orientação alinhada foi muito mais uma consequência que uma opção. Foi, assim, a política externa do pós-1945, e não do governo Dutra. Afinal, se mesmo o governo de Getúlio Vargas (1951-1954), considerado prócer autonomista, não conseguiu escapar ao alinhamento a partir de 1951, não seria razoável esperar que Dutra conseguiria fazê-lo em 1946, quando o "clamor liberal" era ainda mais premente.

O segundo ganho analítico, por sua vez, refere-se à extensão temporal do conceito de "imposição do alinhamento" até, pelo menos, 1954. Dessa forma, é possível interpretar esses dois governos sob uma mesma categoria analítica.

Isso, no entanto, não implica afirmar que as duas gestões foram homogêneas entre si, desconsiderando as diferenças entre ambas. Afinal, caso se analisem as particularidades rigorosamente, não se poderia nem mesmo afirmar que cada um desses governos foi homogêneo em si, pois há grande variedade de políticas, políticos, interesses, grupos de pressão no interior tanto da presidência Dutra quanto da presidência Vargas. 
A despeito disso e da singularidade característica ao tempo histórico, é possível elaborar modelos explicativos (GADDIS, 2004, p. 39-43). Nesse sentido, optou-se por assinalar elementos comuns entre ambas as presidências, de modo a reuni-las sob o mesmo conceito: "imposição do alinhamento".

\subsection{Notas conceituais: Dutra e Vargas}

À primeira vista, o esforço de elaborar uma unidade analítica que compreenda tanto o governo Dutra quanto o Vargas pode causar estranheza. Afinal, eles são, normalmente, apresentados como antípodas.

Assim, foi Vargas que, em seu primeiro governo (1930-1945), inaugurou o paradigma desenvolvimentista (CERVO, 2008a, p. 71), que vigoraria, grosso modo, durante os sessenta anos seguintes (ALBUQUERQUE, 1996). Diz-se grosso modo, pois foi justamente o governo Dutra - e o Castelo Branco - o momento em que não se teria verificado o paradigma desenvolvimentista, de forma que a presidência do ex-ministro da Guerra constituiu, por isso, um passo fora da cadência (CERVO, 2008a, p. 46; BUENO; CERVO, 2012, p. 394).

Essa estranheza, todavia, não deve persistir após a segunda vista. Afinal, ha de se considerar que não se pode comparar o primeiro governo Vargas (1930-1945) com o segundo (1951-1954), pois os contextos nacional e internacional eram bastante distintos entre esses dois períodos. Além disso, mesmo que se considere o primeiro governo Vargas (1930-1945) apenas, há de se recordar que a equidistância pragmática foi rompida em 1942, de modo que o Brasil, ainda sob Getúlio, se alinhou aos Estados Unidos (MOURA, 1980). Assim, não seria de se esperar que, imediatamente após essa data, a política externa brasileira retornasse - seja com Dutra, seja com Vargas - ao pragmatismo anterior, ainda mais em um momento em que os Estados Unidos se tornaram superpotência global.

Outro argumento a dirimir aquela estranheza inicial é o fato de que a própria literatura existente já aproxima os dois governos, ainda que se valendo de categorias analíticas distintas. Isso é o que se depreende dos conceitos que, tradicionalmente, caracterizam a política externa das presidências Dutra (1946-1950) e Vargas (1951-1954), respectivamente: alinhamento sem recompensas (MOURA, 1991) e pragmatismo impossível (HIRST, 1990). 
Afinal, se o pragmatismo não foi possível no governo Vargas, isso implica que houve alinhamento, à semelhança do governo Dutra. Além disso, nos dois governos, a marginalização da América Latina em termos de prioridade para os Estados Unidos levou à falta de recompensas para o Brasil, que as demandava em nome das relações especiais que julgava ter com os norte-americanos.

Assim, é possível concluir que o período entre 1946 e 1954 foi, ele todo, um momento de pragmatismo impossivel (HIRST, 1990) e de alinhamento sem recompensas (MOURA, 1991), independentemente do personagem à frente do Catete. Não à toa, Doratioto e Vidigal (2014, p. 71) informam que, em termos de política externa, o segundo governo Vargas (1951-1954) está mais próximo ao governo Dutra (1946-1950) que ao primeiro governo Vargas (1930-1945).

Nesse sentido, o conceito de "imposição do alinhamento" explicita a semelhança analítica entre a política externa desses dois governos. Faz isso sem pretender negar o pragmatismo impossível (HIRST, 1990) e o alinhamento sem recompensas (MOURA, 1991). Justamente o contrário, a "imposição do alinhamento" afirma-os. Reconhece-lhes relevância e precisão explicativa, pois são capazes de identificar elementos relevantes do período. Tão relevantes que não se restringem apenas aos governos destinatários desses conceitos, mas apreendem o espírito de uma época, caracterizado por este trabalho como "imposição do alinhamento".

\subsection{A "imposição do alinhamento" pelo contexto internacional}

Para os termos do presente capítulo, os elementos do contexto internacional a contribuir para formação da política externa brasileira não se alteraram de maneira profunda, no governo Vargas (1951-1954). Dessa forma, admite-se que o cenário internacional no período apontado foi estruturalmente semelhante ao analisado no capítulo anterior, correspondente ao governo Dutra (1946-1950).

Isso não significa, naturalmente, que não tenham ocorrido fatos novos nesses anos, chegando-se, assim, ao fim da história. Significa, sim, que, de maneira geral, os novos fatos não trouxeram consigo alterações substanciais sobre os elementos do contexto internacional que influenciaram a política externa brasileira. Em consequência, a "imposição do 
alinhamento" continuou a ser alimentada pelo cenário internacional durante os anos do governo Vargas (1951-1954).

Apesar disso, mesmo que não tenham ocorrido alterações profundas, é possível identificar nuances. Assim, gravitando em torno de um centro, a "imposição do alinhamento" foi ora abrandada, ora reforçada sutilmente em decorrência dos acontecimentos no plano internacional, entre 1951 e 1954.

É a análise dessas nuances o objeto de estudo da presente seção. São investigadas a Guerra da Coreia, entre 1950 e 1953; a ascensão de Eisenhower e Kruschev, respectivamente, à Casa Branca e ao Kremlin; e a emergência, esboçada, de novos polos de poder.

\subsubsection{A Guerra da Coreia}

Iniciada em junho de 1950, com a invasão da Coreia do Sul por tropas norte-coreanas (GARCIA, 2005, p. 168), a Guerra da Coreia acrescentou tensão ao que Ikenberry (2001) caracterizou como arranjo bipolar - a relação entre os blocos capitalista e comunista. Foi o local e o momento nos quais as duas superpotências, direta e indiretamente, "jogaram todos os seus esforços na demonstração de poder mundial" (SARAIVA, 2008, p. 210).

Essa é a historiografia mais recente acerca do assunto, derivada, por exemplo, de trabalhos seminais como os de Gaddis (2005a, 2005b). Até recentemente, conforme registra Weathersby (2005, p. 267), argumentava-se que a Guerra da Coreia teria sido uma guerra civil, e não uma conflito entre as duas superpotências. Para tanto, contribuía o fato, inclusive, de que, supostamente, não teria havido participação direta soviética no conflito. Afinal, pelo bloco comunista, o principal beligerante teria sido a República Popular da China - recém saída da revolução de 1949 - que agira em defesa da Coreia do Norte.

Weathersby (2005, p. 267), no entanto, ressalta que a pesquisa documental nos arquivos soviéticos demonstrou que a União Soviética exercia rígido controle sobre a Coreia do Norte, seu Estado satélite na península. Assim, não surpreende que Gaddis (2005a, p. 60) tenha concluído que a Guerra da Coreia fora iniciada por Stalin. Verificou-se, inclusive, que houve confronto direto entre forças militares soviéticas e norte-americanas, a primeira e única vez que isso ocorreu durante toda a Guerra Fria (GADDIS, 2005a, p. 60), caracterizada, como visto, pela natureza indireta dos conflitos entre as duas superpotências. 
Assim, é lícito concluir que a Guerra da Coreia (1950-1953) foi um conflito entre os Estados Unidos e a União Soviética - entre suas respectivas visões de mundo e esferas de influência. Foi, inclusive, "o maior conflito armado desde a Segunda Guerra Mundial" (SARAIVA, 2008, p. 211). Essa interpretação é corroborada pelo número de vítimas fatais decorrentes dos anos de conflito militar direto entre as duas Coreias, entre 1950 e 1953. De acordo com Gaddis (2005a, p. 50), foram 36.586 baixas norte-americanas, 600.000 chinesas e mais de dois milhões coreanas, cifras que a humanidade não imaginava rever em um espaço de tempo tão curto após a Segunda Guerra Mundial.

$\mathrm{Na}$ política externa brasileira, o impacto da Guerra da Coreia (1950-1953) foi o recrudescimento da "imposição do alinhamento". Afinal, diante do conflito direto entre as duas ideologias naquela península e mesmo ante a perspectiva de uma nova guerra mundial (CERVO, 2007, p. 123), a bipolaridade cobrava seu preço sobre o arranjo ocidental (IKENBERRY, 2001). Exigia dos integrantes do bloco demonstração de filiação.

$\mathrm{Na}$ América, essa demonstração foi manifestada de maneira categórica, na IV Reunião de Consulta dos Chanceleres Americanos ${ }^{98}$, no início de 1951. Nela, os Estados Unidos objetivavam "restabelecer a solidariedade continental que se alcançara durante a Segunda Guerra Mundial" (CERVO, 2007, p. 124). Conseguiram-no, embora o envio de tropas à Península da Coreia só tenha sido obtido da Colômbia (CERVO, 2007, p. 72).

A filiação brasileira foi declarada de maneira incisiva, inclusive com a sugestão pelo chanceler João Neves da Fontoura de que o Brasil forneceria colaboração militar (BUENO; CERVO, 2012, p. 302), o que foi impossibilitado por divergências no governo, no Congresso e na sociedade (HIRST, 1990). De toda forma, o Brasil demonstrou seu alinhamento, repudiando a "agressão soviética"99 e atuando em favor da posição norte-americana sobre a questão na ONU. Neste caso, por exemplo, o voto brasileiro foi um dos favoráveis ${ }^{100}$ à

\footnotetext{
${ }^{98}$ Outros elementos dessa conferência serão analisados em sessões posteriores.

${ }^{99}$ Relatório, 1951, p. 12.

${ }^{100}$ A resolução foi aprovada com 52 votos favoráveis, 5 contrários e 2 abstenções. Votaram favoravelmente: Afeganistão, África do Sul, Arábia Saudita, Austrália, Bélgica, Bolívia, Birmânia, Brasil, Canadá, Chile, China, Colômbia, Costa Rica, Cuba, Dinamarca, Egito, El Salvador, Equador, Estados Unidos, Etiópia, Filipinas, França, Grécia, Guatemala, Haiti, Honduras, Irlanda, Indonésia, Irã, Iraque, Iugoslávia, Libéria, Luxemburgo, México, Nicarágua, Noruega, Nova Zelândia, Países Baixos, Panama, Paquistão, Paraguai, Peru, Reino Unido, República Dominicana, Suécia, Tailândia, Turquia, Uruguai, Venezuela. Votaram contrariamente: Checoslováquia, Polônia, República Socialista Soviética da Bielorrússia, República Socialista Soviética da Ucrânia, União Soviética. Abstiveram-se: Argentina, Índia (UNITED NATIONS, General Assembly, Fifth Session, Official Records, 1950, p. 347).
} 
Resolução 377 (Uniting for Peace), que, aprovada graças ao alinhamento da Europa Ocidental e da América Latina aos Estados Unidos, legitimou a intervenção militar norte-americana na Península da Coreia (CORRÊA, 2007, p. 68).

Assim, na esteira da Guerra da Coreia (1950-1953), que desencadeou intenso processo de armamento e insegurança, os Estados Unidos reforçaram sua influência sobre o bloco ocidental (STUECK, 2010, p. 287). Dessa forma, o impacto da Guerra da Coreia sobre a política externa brasileira foi, como dito, o recrudescimento da "imposição do alinhamento".

\subsubsection{A ascensão de Eisenhower e Kruschev}

O ano de 1953 constituiu um marco na história das duas superpotências mundiais e, em consequência, das relações internacionais. Nessa data, a Casa Branca e o Kremlin passaram a ser chefiados por novas lideranças. Dwight Eisenhower e Nikita Kruschevi01 substituíram, respectivamente, Harry Truman e Joseph Stalin. Com isso, alteraram-se as dinâmicas da interação entre os blocos e no interior dos blocos capitalista e comunista.

A Guerra Fria, assim, entrava em uma nova fase, a da coexistência pacifica, conforme expressão cunhada pelo próprio Kruschev (GADDIS, 2005a, p. 70). Na literatura, essa nova fase também foi caracterizada por meio de outras chaves analíticas, como bipolaridade imperfeita (SARAIVA, 2008) e antagonismo oscilatório (HALLIDAY, 1986). Assim como a tipologia, as datas assinaladas também foram diferentes. Nesse sentido, para Saraiva (2008), a bipolaridade imperfeita compreendeu os anos entre 1955 e 1968; enquanto, para Halliday (1986), o antagonismo oscilatório correspondeu ao período entre 1953 e 1969.

Esses conceitos trazem dois ganhos analíticos específicos para esta seção. O primeiro refere-se à periodização proposta pelos conceitos supracitados. Afinal, ao se reconhecer que uma nova fase da Guerra Fria emergiu seja em 1953, seja em 1955, reconhece-se, igualmente, que o período anterior a esses anos também constituiu uma fase própria. Para Halliday (1986), por exemplo, tratou-se do período da Primeira Guerra Fria (1946-1953). Com isso, endossase o argumento apresentado anteriormente de que, durante os governos Dutra e Vargas (1946-1954) - ou, pelo menos, na maior parte desse período -, não houve alterações

\footnotetext{
${ }^{101}$ Após a morte de Joseph Stalin em março 1953, Nikita Kruschev foi nomeado Primeiro Secretário do Comitê Central do Partido Comunista em setembro de 1953, mas sua liderança sobre a União Soviética ainda estaria em cheque até 1955, data em que seu rival, Geórgiy Malenkov, seria destituído do cargo de Primeiro Ministro (RAJAK, 2010, p. 217; GADDIS, 2005a, p. 69).
} 
profundas nos elementos do contexto internacional que contribuíam para a formação da política externa brasileira.

O segundo ganho analítico, a seu turno, deriva do fato de que tais conceitos permitem assimilar que essa nova etapa da Guerra Fria trouxe consigo momentos tanto de arrefecimento quanto de recrudescimento da "imposição do alinhamento". Isso ocorreu, pois, conforme lembra Halliday (1986, p. 6), o antagonismo oscilatório pode ser interpretado como uma mescla entre elementos de confrontação (característica da Primeira e da Segunda Guerra Fria) e negociação (própria à Détente). Nesse sentido, enquanto a negociação entre as duas superpotências abria espaço para que a "imposição do alinhamento" sobre a política externa brasileira fosse atenuada, a confrontação, naturalmente, restringia o espaço de manobra do Brasil no plano internacional, reforçando a "imposição do alinhamento".

Como exemplo da confrontação, podem ser citadas as detonações de bomba de hidrogênio pelos Estados Unidos em novembro de 1952 e pela União Soviética em agosto de 1953. Com isso, a guerra nuclear avançava, ao ganhar um novo componente. Diante desse cenário, reforçava-se, em consequência, a necessidade dos integrantes dos blocos capitalista e comunista de se albergarem sob a proteção das respectivas superpotências. No caso brasileiro, reforçava-se a "imposição do alinhamento".

Essa situação era intensificada, pois a expansão dos respectivos arsenais nucleares foi um objetivo comum das duas superpotências durante as gestões de Eisenhower e Kruschev (GADDIS, 2005a). No caso específico dos Estados Unidos, essa expansão tornou-se um dos elementos centrais da política de defesa de Eisenhower, caracterizada como New Look e desenhada no NSC 162/2, de 1953 (MCMAHON, 2010, p. 293). Nesse sentido, registrou-se no NSC 162/2, por exemplo, que "the risk of Soviet aggression will be minimized by maintaining a strong security posture, with emphasis on adequate offensive retaliatory strength and defensive strength. This must be based on massive atomic capability"102.

Alem disso, pelo menos dois outros elementos da nova política de defesa dos Estados Unidos, New Look, também tiveram impacto direto sobre a política externa brasileira. O primeiro foi a revisão nos gastos governamentais norte-americanos, que se encontravam em espiral de crescimento ao final da gestão Truman (MCMAHON, 2010, p. 291). Essa revisão era parte da plataforma da campanha presidencial de Eisenhower, que, por exemplo, declarou:

102 FRUS, "S/S-NSC files, lot 63 D 251, NSC 162" (30 de outubro de 1953). 
"the real problem is to build the defense with wisdom and efficiency. We must achieve both security and solvency. In fact, the foundation of military strength is economic strength. A bankrupt America is more the Soviet goal than an America conquered on the field of battle $^{103}$.

A obsessão de Eisenhower com a situação fiscal do país decorria da percepção de que a maior ameaça à segurança nacional dos Estados Unidos era, principalmente, o excessivo gasto público (MCMAHON, 2010, p. 289). Assim, não surpreende que o NSC 162/2 tenha se iniciado com as seguintes considerações: "Basic problems of national security policy: 1.a. To meet the Soviet threat to U.S. security; b. In doing so, to avoid seriously weakening the U.S. economy"104.

Para o Brasil, esse aspecto da reorientação da política de defesa norte-americana implicou o abandono de projetos de cooperação pelos Estados Unidos. O exemplo mais simbólico disso foi o encerramento unilateral pela administração Eisenhower da Comissão Mista Brasil - Estado Unidos, questão que será retomada em seção posterior.

O país foi igualmente afetado por outro aspecto da política do New Look, de Eisenhower. Em consequência do esforço de contenção de gastos, a nova política de defesa norte-americana valorizou sobremaneira o aparelho estatal de inteligência e informação. Por exemplo, ganhou destaque a Central Intelligence Agency (CIA), que seria chefiada por Allen Dulles, irmão do secretário de Estado (MCMAHON, 2010, p. 294).

Dessa forma, seguiram-se operações secretas no exterior, como as que contribuíram para a derrubada de governos identificados como de esquerda ${ }^{105}$ no Irã, em 1953 e na Guatemala, em 1954 (BRADLEY, 2010, p. 477-479). Essas situações reclamaram, direta ou indiretamente, posicionamento brasileiro ante ao alinhamento, o que foi verificado especialmente no caso guatemalteco, conforme se analisará posteriormente.

Também em decorrência da valorização do aparelho estatal de inteligência e informação, em junho de 1953, foi criada a United States Information Agency (USIA), que trabalhou ativamente na formulação e na distribuição de notícias. No Brasil, a atuação dessa nova agência contribuiu para o recrudescimento da "imposição do alinhamento", ainda que de

\footnotetext{
${ }^{103}$ New York Times, edição de 26 de setembro de 1952, p. 12.

${ }^{104}$ FRUS, "S/S-NSC files, lot 63 D 251, NSC 162" (30 de outubro de 1953).

${ }^{105}$ Esses casos ilustram o argumento de McMahon (2010, p. 301) de que o governo Eisenhower não soube lidar com o fenômeno do nacionalismo, confundido-o, frequentemente, com comunismo.
} 
maneira indireta. Afinal, conforme apontado por Cattai (2011, p. 42), a USIA difundiu conteúdo anticomunista e pró-americano em jornais brasileiros, nomeadamente Correio da Manhã e Tribuna da Imprensa. No ano de 1953 apenas, "a agência de informação e propaganda veiculou com crédito, aproximadamente, sessenta e uma notícias" (CATTAI, 2011, p. 43). Dessa forma, também por meio da USIA, a nova política de defesa dos Estados Unidos, New Look, contribuiu para alimentar o anticomunismo e o alinhamento da polarizada e tensionada sociedade brasileira do período (BARBOSA, 2003).

\subsubsection{A emergência de novos polos de poder}

Como dito anteriormente, fatos novos no âmbito internacional também resultaram em atenuação da "imposição do alinhamento". Esse foi o caso, particularmente, da emergência de novos polos de poder, que, nesse período, se ensaiava.

Essa emergia decorria, em parte, do próprio contexto de antagonismo oscilatório (HALLIDAY, 1986). Afinal, tanto Eisenhower quanto Kruschev empenhavam-se em evitar uma nova guerra total, apesar se prepararem para ela. Quanto à justificativa para essa postura, é ilustrativa a fala de Eisenhower ao presidente da República da Coreia, Syngman Rhee: "atomic war will destroy civilizations [...]. War today is unthinkable with the weapons which we have at our command. If the Kremlin and Washington ever lock up in a war, the results are too horrible to contemplate. I can't even imagine"106.

Era a lógica da destruição mutuamente assegurada (HOBSBAWM, 1995), de modo que ambos os líderes procuraram estabelecer relações mais estáveis entre as duas superpotências (GADDIS, 2005a, p. 71). Em consequência, essa relativa distensão entre Estados Unidos e União Soviética ampliava, em graus variados, a margem de manobra no cenário internacional dos integrantes dos respectivos blocos (SARAIVA, 2008, p. 212-214). Atenuava-se, assim, a "imposição do alinhamento" sobre a política externa brasileira.

Nesse contexto, insere-se a eclosão do nacionalismo, considerada por McMahon (2010, p. 300) "the single most dynamic new element in international affairs during the Eisenhower years". Independentemente da forma que assumiu - descolonização, independência, expropriação, protecionismo -, o nacionalismo esteve, comumente, associado

${ }^{106}$ FRUS, "Hagerty Diary, July 27, 1954". 
a uma tentativa de obter maiores ganhos no cenário internacional marcado pela rigidez da bipolaridade. Verificou-se, principalmente, em países em desenvolvimento da Ásia, da África e da América Latina, que constituíam, juntos, o que Alfred Sauvy (1952) conceituou como terceiro mundo.

Esse movimento nacionalista do terceiro mundo (SAUVY, 1952) ganhava densidade e iria desembocar na Conferência de Bandung, em abril de 1955 (BRADLEY, 2010, p. 479), sob a liderança de Sukarno, Nehru e Nasser. Nela, esboçou-se o "não alinhamento", segundo o qual os países não se comprometiam com nenhum dos lados da Guerra Fria, mas deixavam aberta a possibilidade de fazê-lo (GADDIS, 2005a, p. 124). Tratava-se, assim, de uma espécie de barganha que países menores tentavam empreender por meio da ameaça de se aliarem à superpotência rival.

Essa onda nacionalista atingia até países que se alinhavam aos blocos capitalista ou comunista. Inclusive, Gaddis (2005a, p. 124) aponta que essa tentativa de barganha teria sido iniciada pela Iugoslávia de Tito, inserida na zona de influência soviética. No mundo ocidental esse fenômeno também se verificou, como exemplifica o Brasil do governo Vargas, que procurou pautar sua política externa por uma barganha nacionalista (VISENTINI, 1996), o que pode ser interpretado como uma atenuação da "imposição do alinhamento" ${ }^{107 .}$

Outro fenômeno que merece atenção foi a recuperação econômica da Europa Ocidental (HITCHCOCK, 2010) e do Japão (GUTHRIE-SHIMIZU, 2010). Isso criava novos polos de poder, ampliando, por exemplo, as possibilidades de parcerias comerciais para o Brasil $^{108}$. Como exemplo, podem-se citar a organização, em 1953, da Comissão Mista Brasil Alemanha de Desenvolvimento Econômico e o fato de que a RFA já ser, então, o segundo maior exportador para o Brasil, superado só pelos Estados Unidos (GARCIA, 2005, p. 172).

Dessa forma, com a emergência de novos polos de poder, tendia-se ao abrandamento da "imposição do alinhamento". Por um lado, a onda nacionalista que percorria o terceiro mundo (SAUVY, 1952) e mesmo os mundos capitalista e comunista buscava extrair maiores ganhos da ordem bipolar. Por outro, com a recuperação econômica da Europa Ocidental e do Japão, diminuía-se, potencialmente, a dependência brasileira ante os Estados Unidos.

\footnotetext{
${ }^{107}$ A onda nacionalista sobre a política brasileira e a barganha nacionalista (VISENTINI, 1996) serão objeto de estudo em seção posterior.

108 O surgimento desses novos polos, particularmente no caso europeu, também criaria desafios para o Brasil, como o posto pela formação do Mercado Comum Europeu (BUENO; CERVO, 2012, p. 319). Para os fins desta seção, optou-se, todavia, por ressaltar as oportunidades advindas para o governo Vargas (1951-1954).
} 


\subsection{Retorno de Vargas, continuação do alinhamento}

Em 1951, Getúlio Vargas retornou à Presidência - pela primeira vez por meio do voto popular (FAUSTO, 2013). Vargas creditou sua vitória aos ideais "da liberdade, da garantia e da legitimidade do voto popular"109.

Iniciou o mandato tentando reeditar o papel que desempenhara de "árbitro diante das diferentes forças sociais" (FAUSTO, 2009, p. 406). Dois fatores principais, contudo, impediam isso. $\mathrm{O}$ primeiro era o antigetulismo, que crescera significativamente, como demonstrou a tentativa da oposição de impugnar a eleição pela falta de maioria absoluta (tabela 4), embora a Constituição Federal de 1946 não o exigisse. A propósito, nenhum outro presidente fora Dutra iria alcançar maioria absoluta nas eleições presidenciais durante o resto da República Liberal-Conservadora.

\begin{tabular}{|cccc|} 
& \multicolumn{3}{c}{ Eleições presidenciais de 1950} \\
& Número de votos & \% (total) & \% (válidos) \\
\hline Getúlio Vargas (PTB) & $\mathbf{3 . 8 4 9 . 0 9 0}$ & $\mathbf{4 6 , 6 3}$ & $\mathbf{4 8 , 7 3}$ \\
Eduardo Gomes (UDN) & $\mathbf{2 . 3 4 2 . 3 8 4}$ & $\mathbf{2 8 , 3 9}$ & $\mathbf{2 9 , 4 2}$ \\
Cristiano Machado (PSD) & $\mathbf{1 . 6 9 7 . 1 9 3}$ & $\mathbf{2 0 , 5 6}$ & $\mathbf{2 1 , 4 9}$ \\
João Mangabeira (PSB) & $\mathbf{9 . 4 6 6}$ & $\mathbf{0 , 1 1}$ & $\mathbf{0 , 1 2}$ \\
brancos e nulos & $\mathbf{3 5 6 . 9 0 6}$ & $\mathbf{4 , 3 2}$ & - \\
\hline
\end{tabular}

Tabela 4. Elaborada pelo autor a partir de dados obtidos em TSE (1952).

O segundo fator, a seu turno, era a divisão profunda da sociedade brasileira. Para isso contribuiu um processo igualmente acentuado de complexificação social por que passava o Brasil da época (BARBOSA, 2003). Assim, como novos grupos emergiram - ou, pelo menos, ganharam mais visibilidade -, a arena política brasileira tornou-se mais segmentada.

A divisão social brasileira era agudizada também pelo próprio retorno de Vargas ao poder. Afinal, sua destituição em 1945 justificara um golpe de Estado e a instituição de um novo regime político, fundado em oposição ao Estado Novo varguista. Desse modo, o retorno de Getúlio apenas cinco anos após sua queda produziu inconformação em muitos dos que

\footnotetext{
109 Getúlio Vargas, "Discurso pronunciado ao receber, no Tribunal Superior Eleitoral, o diploma de Presidente da
} República" (27 de janeiro de 1951). 
haviam patrocinado aquele golpe de Estado (FERREIRA, 2003, p. 306). Não à toa, havia mesmo quem, objetivando impedir que esse retorno ocorresse, defendesse que a Justiça Eleitoral não concedesse registro à candidatura de Getúlio Vargas (DELGADO, 2006, p. 78). Assim, por exemplo, Carlos Lacerda defendeu em seu jornal, Tribuna da Imprensa, em 14 de junho de 1950:

O regime democrático tem o direito de se defender dos seus inimigos, prevenindo antes que remediando, em face de perigos evidentes.

A candidatura de um líder totalitário viria pôr em perigo a estrutura do regime e, na hipótese de vir a ser vitoriosa, importaria na destruição do regime democrático com as próprias armas que este faculta aos que desejam colaborar para a sua manutenção e aperfeiçoamento.

Se é legal cancelar o registro de um partido político por ser de natureza contrária ao espírito da Constituição e à essência do regime, como foi o caso do Partido Comunista, ainda mais evidente é a possibilidade de simplesmente negar registro a uma candidatura cujo sentido, pelos antecedentes e pela conduta do candidato, é inequivocamente totalitário. ${ }^{110}$

Os esforços, no entanto, de Lacerda - e do grupo em que estava incluído - foram em vão, pois, efetivamente, não havia nenhum impeditivo legal que fundamentasse tal medida pela Justiça Eleitoral. Assim, Vargas não apenas obteve o registro de sua candidatura, como também venceu as eleições, agudizando as divisões na sociedade brasileira.

É nesse tenso contexto que se desenvolveram as política externa e interna do governo Vargas (1951-1954). A elas passa-se a dedicar.

\subsubsection{Configuração política nacional após as eleições de 1950}

Um primeiro passo para se compreender as políticas interna e externa do governo Vargas - e, consequentemente, a "imposição do alinhamento - é averiguar a configuração político-partidária que resultou das eleições de 1950. Seu resultado possibilita o duplo benefício de revelar o espírito do tempo e de indicar as forças políticas que iriam se colocar para a presidência varguista.

Nesse sentido, além das eleições presidenciais, já apresentadas acima, destacaram-se as eleições para o Congresso Nacional. Afinal, em outubro de 1950, tanto a Câmara dos Deputados (em sua totalidade) quanto o Senado Federal (em um terço de seus membros ${ }^{111}$ ) foram renovados (tabela 5).

110 Tribuna da Imprensa, edição de 14 de junho 1950, p. 1, 10.

${ }^{111}$ No Senado Federal, foram renovados vinte e dois assentos: um para cada um dos vinte Estados e dois para o Distrito Federal. Neste, devido à vacância, elegeu-se um senador a mais que nos outros entes federativos. 


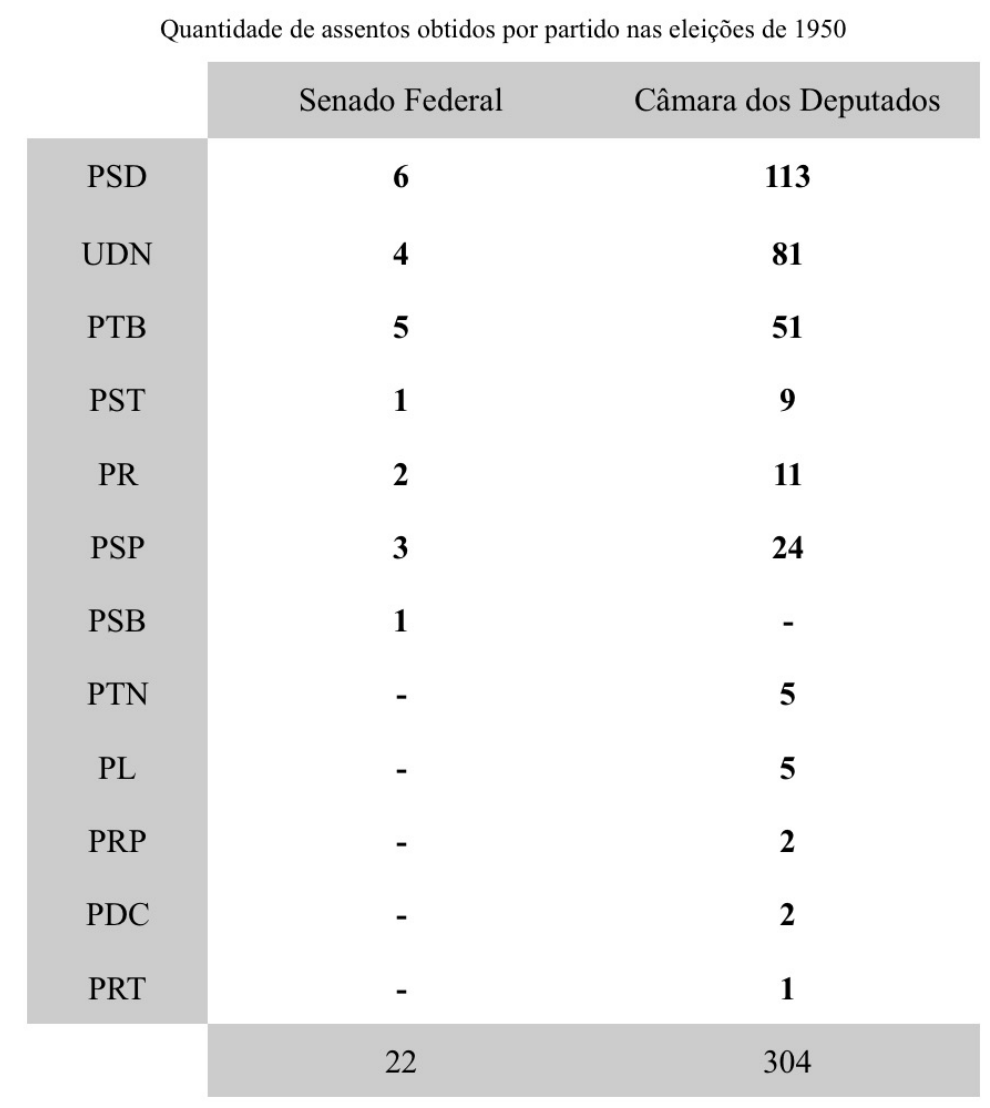

Tabela 5. Elaborada pelo autor a partir de dados obtidos em TSE (1952).

A análise comparativa entre as eleições de 1945 (tabela 2, capítulo 01) e as de 1950 (tabela 5) evidencia um crescimento do nacionalismo no espectro político nacional. Afinal, avaliando-se as três principais agremiações políticas, o partido que mais cresceu nesse período foi o PTB, cuja participação na Câmara dos Deputados passou de 7,69\% para 16,78\% (tabela 6). Esse aumento operou-se em detrimento de partidos mais identificados no amplo espectro liberal. Assim, no mesmo período, o PSD viu sua participação diminuir de 52,80\% para $37,17 \%$, enquanto a UDN, de $29,02 \%$ para $26,64 \%$.

Caso se considerem os valores referente ao Senado Federal, o movimento de nacionalização da política brasileira foi ainda mais evidente. Isso é o que demonstra a análise da proporção dos assentos em disputa obtida pelos partidos. É verdade, no entanto, que o número de vagas em disputa foi distinto, de modo que a comparação entre as duas eleições deve ser vista com ressalvas. Isso posto, também se verificou um notável crescimento do PTB, que ganhou 4,76\% dos assentos em disputa em 1945 e 22,72\% em 1950. Da mesma forma que na Câmara dos Deputados, o crescimento petebista no Senado foi alcançado às custas do PSD e da UDN (tabela 6). 


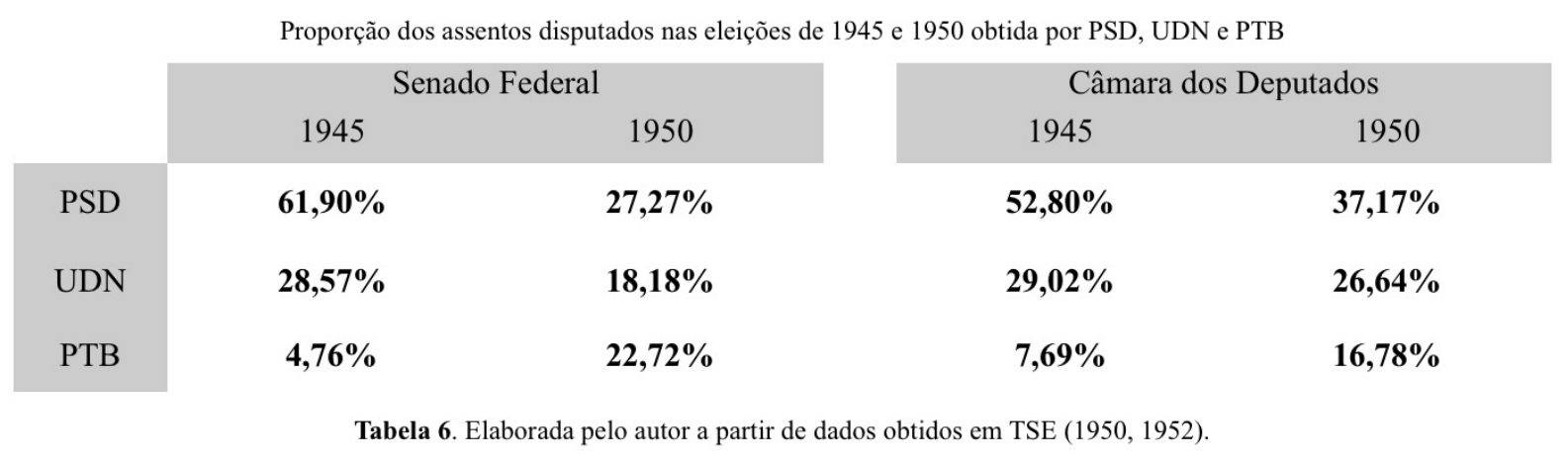

Em termos de política interna, esses números indicam, como dito, uma nacionalização no jogo de forças brasileiro. Em termos de política externa, o crescimento das forças nacionalistas aponta, conforme registra Gelson Fonseca (2001), para o fortalecimento das aspirações por autonomia. Não à toa, Visentini (1996) informa que a volta de Vargas ao Catete foi marcada pela busca da barganha nacionalista. Essa caracterização é endossada por outros autores, como Amado Cervo (2007, 2008a) e Moniz Bandeira (1973, 2003). O contraponto seria a política externa entreguista de Dutra (VISENTINI, 2013b), em cujo governo grupos pertencentes ao amplo espectro liberal exerceram influência.

A conversão de forças nacionalistas domésticas em política externa autônoma - e angariadora de recompensas -, no entanto, não ocorreu. Assim, a despeito do movimento de nacionalização da política interna brasileira após as eleições de 1950, a inserção internacional do país não conseguiu escapar ao alinhamento, conforme se verá em sessões seguintes. Dessa forma pragmatismo foi impossivel (HIRST, 1990) no governo Vargas (1951-1954) - do mesmo modo que o fora no governo Dutra (1946-1950).

Esse cenário corrobora a ideia de "imposição do alinhamento". Afinal, a política externa alinhada impôs-se mesmo com a volta de Vargas, quem inaugurara o paradigma desenvolvimentista (CERVO, 2008a); e com o fortalecimento dos grupos nacionalistas, que pressionariam por uma inserção internacional autonomista (FONSECA, 2001).

Com isso, reforçam-se duas hipóteses levantadas ao longo deste trabalho. A primeira é a possibilidade de estender ao governo Vargas (1951-1954) a aplicação do conceito de "imposição do alinhamento". Em consequência, reforça-se a segunda hipótese: o alinhamento aos Estados Unidos foi muito mais uma imposição dos fatores internos e externos do período que uma opção do governo Dutra (1946-1950). Assim, entre os anos de 1946 e 1954, o alinhamento impôs-se, independentemente do personagem à frente do Catete. 


\subsubsection{A "barganha nacionalista" e o "pragmatismo impossível"}

Argumentar que a política externa de Vargas (1951-1954) também foi caracterizada pela "imposição do alinhamento" não implica necessariamente negar que esse governo tenha tentado empreender uma barganha nacionalista (VISENTINI, 1996). Ao contrário, é possível, mesmo, que essas duas ideais coexistam.

Afinal, conforme apresentado no capítulo anterior, a "imposição do alinhamento" pode ser interpretada segundo duas vertentes: uma positiva (medidas alinhadas), outra negativa (medidas de resistência). Nesse sentido, é possível associar a busca de barganha nacionalista (VISENTINI, 1996) à vertente negativa da "imposição do alinhamento". Assim, esse conceito traduz o esforço associado à nacionalização da política doméstica brasileira nas eleições de 1950 (FONSECA, 2001) no sentido de implementar uma política externa menos alinhada (mais autonomista) por meio da qual mais recompensas fossem angariadas.

O conceito de barganha nacionalista (VISENTINI, 1996), no entanto, não captura a vertente positiva da "imposição do alinhamento". Desse modo, um amplo conjunto de medidas apresentando graus variados de alinhamento parece invisível a esse conceito - mas não à literatura como um todo, pois, como visto, a política externa de Vargas (1951-1954) também é caracterizada pela ideia de pragmatismo impossivel (HIRST, 1990).

É diante desse cenário que se reforça a utilidade do conceito de "imposição do alinhamento". Por um lado, sua formulação vale-se de esforços analíticos anteriores, como barganha nacionalista (VISENTINI, 1996) e pragmatismo impossível (HIRST, 1990). Por outro, procura-se analisar a política externa varguista de modo mais abrangente, incluindo manifestações tanto de alinhamento (vertente positiva) quanto de resistência a este (vertente negativa). São essas manifestações, em suas vertentes positiva e negativa, que serão objeto de estudo nas sessões seguintes.

\subsubsection{Resistência ao alinhamento}

Sob o impulso das forças nacionalistas vencedoras nas eleições de 1950, Getúlio Vargas teria iniciado seu segundo mandato presidencial sob o signo da busca de autonomia. Por isso, é pela vertente negativa - medidas que, em graus variados, objetivaram revisões no 
alinhamento à superpotência ocidental, os Estados Unidos - que se começa a análise da política externa desse período, 1951-1954.

Antes mesmo do início do governo, essa trajetória já estava traçada. Assim, ainda em campanha, Vargas indicava que sua política externa seguiria diretrizes paralelas às de seu governo anterior, "sobretudo na fase que antecedeu e sucedeu a entrada do Brasil na guerra"112. Nesse período, "o ideal de Bolívar foi enriquecido pela experiência de uma política fraterna de aproximação e solidariedade entre as Nações da América". Em sinal claro de desconformidade com a política externa de Dutra e em defesa de um novo direcionamento, Vargas ressaltou que "o pan-americanismo não deve nem pode estabelecer sujeições ou dependências além dos tratados livremente consentidos entre os governos", lição cujo mérito "a época atual [a do governo Dutra] o atesta ainda mais claramente" [grifo nosso].

Essas passagens, repetidas literalmente em outros discursos durante a campanha, são bastante eloquentes quanto aos traços que iriam orientar a política externa do segundo governo Vargas (1951-1954). Nesse sentido, verifica-se, conforme ressaltando na literatura (HIRST, 1996, p. 213), a tentativa de restaurar o padrão de inserção internacional adotado em seu primeiro governo (1930-1945).

Esse padrão, principalmente após o rompimento da equidistância pragmática (MOURA, 1980), era caracterizado pelo alinhamento negociado com os Estados Unidos (DORATIOTO; VIDIGAL, 2014, p. 70). Os elementos desse padrão também estiveram presentes nas passagens supracitadas. Afinal, por um lado, Vargas destacou a "aproximação e solidariedade entre as Nações da América" e, por outro, ressaltou que o pan-americanismo deveria ser compatível com a independência nacional.

Por meio dessa estratégia, o objetivo era implementar o que Visentini (1996) conceituou como barganha nacionalista. Assim, o Brasil apoiaria os Estados Unidos no âmbito político-estratégico da Guerra Fria; em retribuição, esperava receber auxílio para o projeto brasileiro de desenvolvimento econômico (VISENTINI, 2013b, p. 203).

Essa estratégia de barganha nacionalista (VISENTINI, 1996) também pode ser depreendida a partir da análise dos discursos da campanha presidencial de 1950. Afinal, sobre a interação do pan-americanismo e a política externa de um eventual novo governo, Getúlio argumentava que "as necessidades do desenvolvimento dos países mais atrasados exigem que 
não se esgote a OEA apenas em fórmulas eloquentes, mas que se concretize em obras de cooperação mútua, no terreno espiritual, cultural e econômico"113.

O tom da barganha nacionalista (VISENTINI, 1996) estava dado. Seus ecos alcançavam, inclusive, o Departamento de Estado norte-americano. Assim, em memorando enviado ao presidente Harry Truman, o secretário de Estado Dean Acheson informou que, se eleito, "Vargas undoubtedly would make aggressive and persistent claims upon the United States for financial and other types of assistance" 114 .

Com a vitória de Vargas em outubro de 1950, esse diagnóstico concretizou-se. Nesse sentido, ainda como presidente eleito, encaminhou, em 13 de janeiro de 1951, por meio de João Neves da Fontoura, um memorando à embaixada norte-americana. Nesse documento, conhecido como "documento Vargas", apresentou sua barganha nacionalista (VISENTINI, 1996): "the Brazilian government requires the positive support of the North American Government so that orders of materials needed for the establishment of basic industries and the execution of public works will move forward quickly and have priority of delivery"115.

O pedido de auxílio abrangia iniciativas diversas em várias áreas. Previam-se construção de hidrelétricas, ampliação da capacidade de refino de petróleo, ampliação da usina de Volta Redonda, construção de indústrias de nitrato sintético e álcalis, melhoramento e ampliação das linhas férreas e das instalações portuárias, exploração de carvão e de outras matérias-primas, suprimento de equipamentos para manutenção da aviação, financiamento para transporte e estabelecimento de imigrantes italianos. "These points, listed as examples [...], represent in synthesis the cooperation that the government of Brazil expects from the US for the realization of an unpostponable economic development program".

Pela amplitude das iniciativas e pela literalidade do documento, verifica-se, assim, que o apoio solicitado aos Estados Unidos pelo governo Vargas não se referia a uma cooperação pontual, mas a um verdadeiro "programa de desenvolvimento econômico". Diante desse cenário, o subsecretário de Estado Edward Miller ponderou junto ao secretário Dean Acheson que: "it is imperative for the future of our relations with Brazil that we give a positive response to the proposals of President Vargas, even though the realization of the entire

\footnotetext{
${ }^{113}$ CPDOC, GV rem.s 1950.01.28.

${ }^{114}$ FRUS, "Memorando 611.35/5-150" (01 de maio de 1950).

115 FRUS, "Telegrama 832.00/1-1551" (15 de janeiro de 1951).
} 
program is obviously not a short-term possibility". Dessa forma, os Estados Unidos deveriam, em sua opinião, "express a willingness to begin to lay plans for the ultimate realization of the program and to proceed immediately with the highest priority items"116.

Nesse contexto, a política externa brasileira parecia escapar à "imposição do alinhamento" no governo Vargas, que ainda não tinha nem começado. Afinal, a barganha nacionalista (VISENTINI, 1996) aparentava alvissareira, embora faltasse-lhe um palco onde pudesse ser desenvolvida plenamente e um meio para concretizá-la. Ambos seriam providos, ao que tudo indicava, ainda em 1951, com, respectivamente, a IV Reunião de Consulta dos Chanceleres Americanos e a Comissão Mista Brasil - Estados Unidos para o Desenvolvimento Econômico (CMBEU).

\subsubsection{O palco: a Conferência de Washington}

Realizada entre março e abril de 1951, a IV Reunião de Consulta dos Chanceleres Americanos - ou, simplesmente, Conferência de Washington - foi o palco privilegiado para o exercício da barganha nacionalista (VISENTINI, 1996). Nessa reunião, o Brasil moveu-se, decisivamente, para a tentativa de implementar revisões em seu relacionamento bilateral com os Estados Unidos. Constituiu, dessa forma, uma manifestação de resistência à "imposição do alinhamento" - vertente negativa, que, como dito, comportou diversos graus.

A Conferência de Washington foi convocada "em virtude da ameaça que a atitude agressiva do comunismo internacional representava [...] para todas as Nações livres e necessariamente para esta parte do Hemisfério [América]"117. Seu pano de fundo era a Guerra da Coreia, iniciada em 1950, e a correlata expansão soviética.

Nesse contexto, os Estados Unidos mobilizaram sua economia de guerra, na qual a América Latina teria um papel a desempenhar. Afinal, esse "grande plano de mobilização econômica para a defesa" também envolvia a "mobilização dos recursos do hemisfério, suprimento de matérias-primas e manufaturas"118. Era a situação ideal para tentar efetivar a barganha nacionalista (VISENTINI, 1996).

\footnotetext{
${ }^{116}$ FRUS, "Memorando 832.00/1-2551" (25 de janeiro de 1951).

${ }^{117}$ Relatório, 1951, p. 8.

${ }^{118}$ Ibidem, p. 13.
} 
Nesse sentido, para o Brasil, a Guerra da Coreia seria uma moeda de troca, como o fora a Segunda Guerra Mundial. Assim, vislumbrava-se o momento adequado para resgatar o alinhamento negociado (DORATIOTO; VIDIGAL, 2014, p. 70-71) e, consequentemente, a política externa dos anos 1942-1945, objetivos, como visto, explicitamente manifestados por Vargas em seus discursos de campanha. Desse modo, mais uma vez, Getúlio tentaria associar concessões brasileiras no âmbito militar a investimentos norte-americanos no âmbito produtivo (PINHEIRO, 2004, p. 29).

Essa tentativa de revisar o relacionamento com os Estados Unidos - uma manifestação de resistência à "imposição do alinhamento" - era operacionalizada por uma estratégia já utilizada na época por países da Europa Ocidental. Tratou-se, nomeadamente, do fantasma da ameaça do comunismo (IKENBERRY, 2001, p. 193).

No caso europeu, como visto, a "ameaça comunista" referia-se à expansão da esfera de influência soviética em um território disputado entre as duas superpotências no qual governos comunistas já se faziam presentes. No caso americano - e, especificamente, brasileiro -, a "ameaça comunista" era utilizada em território considerado domínio natural dos Estados Unidos, no qual o comunismo não teria acesso às chefias de governo.

Essas diferenças implicaram, em consequência, opções distintas para fazer frente à "ameaça comunista" nos dois locais. Na Europa Ocidental, dominou a estratégia de contenção, cujas diretrizes foram tributárias das ideias de Kennan (1947). Assim, nesse continente, a Guerra Fria foi operacionalizada em plenitude, de modo que a disputa ideológica incorporou elementos psicológicos, bélico-militares, econômico-financeiros (GADDIS, 2005b), conforme analisado no capítulo anterior.

$\mathrm{Na}$ América, justamente por ser considerada integrante natural da esfera influência norte-americana, aqueles elementos da Guerra Fria apresentaram formas atenuadas. É verdade, no entanto, que o elemento bélico-militar foi largamente utilizado pelos Estados Unidos na América Central (BULL, 2002, p. 246-248). Apesar disso, de maneira geral, a América foi negligenciada pela estratégia de contenção norte-americana, especialmente no elemento econômico-financeiro, como visto no capítulo anterior.

Foi diante desse cenário que o governo brasileiro, na Conferência de Washington, procurou associar o comunismo ao subdesenvolvimento econômico. Era uma postura reivindicatória - de resistência à "imposição do alinhamento" - fundada sobre o argumento de 
que a América Latina, por seu subdesenvolvimento, também sofria ameaça direta e imediata do comunismo. Assim, tentava-se obter auxílio dos EUA ao desenvolvimento nacional, ponderando que a miséria era o maior risco à democracia, de modo que, ao promover-se o desenvolvimento econômico latino-americano, combatia-se o comunismo na região (DALIO; MIYAMOTO, 2009; BUENO; CERVO, 2012).

A estratégia brasileira foi ecoada pelos outros países latino-americanos. Ganhou respaldo e fez-se presente na ata final da Reunião de Consulta. Nela, foi consagrado o princípio de que "o desenvolvimento econômico dos países insuficientemente desenvolvidos é considerado como elemento essencial sob o ponto de vista da defesa do continente" ${ }^{119}$. Foi uma vitória da estratégia do Brasil, um esforço de revisão no relacionamento com os Estados Unidos, uma manifestação de resistência à "imposição do alinhamento".

\subsubsection{O meio: a Comissão Mista Brasil - Estados Unidos}

Em julho de 1951, foi instalada a Comissão Mista Brasil - Estados Unidos para o Desenvolvimento Econômico (CMBEU), que fora criada em dezembro de 1950, ainda no governo Dutra (LEOPOLDI, 1994). O Brasil forneceria matérias-primas estratégicas, principalmente manganês e areias monazíticas (HIRST, 1990, p. 8). Os EUA ofereceriam assistência técnica para "identificar projetos preponderantemente de desenvolvimento da infraestrutura", os quais serviriam "de base para os pleitos brasileiros de financiamento em Washington" (ABREU, 2013, p. 205).

Dessa forma, a CMBEU parecia concretizar a barganha nacionalista (VISENTINI, 1996). Afinal, o pleito brasileiro, reiterado constantemente após a Segunda Guerra Mundial, de financiamento governamental para projetos de desenvolvimento nacional aparentava contemplado. A política externa brasileira parecia ter conseguido distanciar-se do padrão de alinhamento sem recompensas (MOURA, 1990), do governo Dutra. O contraste com este governo foi, inclusive, explícito, conforme se lê em carta da João Neves da Fontoura a Getúlio Vargas: "não julgo desprezível a quantia de 250 milhões de dólares (o Dutra não arranjou um centavo dos americanos durante 5 anos!)" ${ }^{120}$.

\footnotetext{
119 Relatório, 1951, p. 14-15.

120 CPDOC, GV c. $1951.02 .19 / 1$.
} 
A "imposição do alinhamento" enfrentava uma manifestação de resistência por meio da CMBEU. Afinal, a dinâmica do relacionamento bilateral parecia estar sendo moldada a partir de um pleito do Brasil, que demandava financiamentos governamentais; e não dos Estados Unidos, que tinham preferência pela concessão de financiamentos privados.

A CMBEU, assim, parecia indicar que a posição internacional do Brasil tinha melhorado, já que o país aparentava estar conseguindo extrair mais dividendos de sua política externa. Esta afigurava-se concretizando o objetivo que lhe havia sido vislumbrado por Vargas ainda na campanha presidencial: promoção do desenvolvimento nacional. Afinal, com a CMBEU, o Brasil obteria financiamento a projetos de infraestrutura e a desobstrução, por meio desses projetos, dos gargalos estruturais do país (VIENNA, 2014).

É por essa instrumentalização da política externa, inclusive, que Pinheiro (2004) conceitua o tipo de americanismo desenvolvido no governo Vargas como americanismo pragmático. Seu contraste, como visto, seria o americanismo ideológico, supostamente adotado durante o governo Dutra.

\subsubsection{Outras manifestações de resistência}

As manifestações anteriores - a Conferência de Washington e a CMBEU - ilustram, de maneira clara, a vertente negativa (resistência) da "imposição do alinhamento" durante o governo Vargas (1951-1954). Nesse sentido, apontam uma tentativa de requalificar a política externa brasileira do pós-1945, alinhada aos Estados Unidos. Outras manifestações também sugerem a mesma direção. Nesta seção, citam-se algumas, com o intuito de fortalecer o argumento da vertente negativa da "imposição do alinhamento", inclusive demonstrando-a em outros âmbitos da política brasileira.

No âmbito militar, por exemplo, foi nomeado para o importante Ministério da Guerra o general Estillac Leal, antigo "tenente" e avalista do apoio militar à posse de Getúlio em janeiro de 1951 (DEVOTO; FAUSTO, 2004, p. 312). Fora ele quem assegurou, ainda durante a campanha presidencial, a João Neves da Fontoura que o Exército e as classes armadas estavam "totalmente contrárias a qualquer golpe ou violação constitucional" e que, por isso, iriam empossar o candidato eleito ${ }^{121}$.

${ }^{121}$ CPDOC, GV c 1950.05.00/13. 
A escolha de Estillac Leal foi indicativa de uma resistência à "imposição do alinhamento", pois ele era um dos principais expoentes do grupo de oficiais nacionalistas (MARTINS FILHO, 2013, p. 112). Esse grupo, em oposição aos antinacionalistas, eram manifestamente contrários à política externa de alinhamento aos Estados Unidos (MARTINS FILHO, 2013, p. 112-113). Quem o disse, inclusive, foi o próprio Estillac Leal, que, em conversa com João Neves da Fontoura, se caracterizou como "anti-yankee, no sentido de anticapitalista e anti-imperialista", manifestando-se também como "anti-Dutra" 122.

No âmbito econômico, igualmente, houve diversas manifestações de resistência à "imposição do alinhamento". Afinal, segundo Bastos (2015, p. 359), Vargas iniciou seu governo em 1951 sob um perspectiva econômica desenvolvimentista, na qual estavam presentes a crítica ao liberalismo econômico, o elogio ao ativismo estatal na economia, a recusa da contração creditícia e monetária, a rejeição da abertura comercial e financeira.

É o que se depreende, mesmo, da Mensagem ao Congresso Nacional de 1951, na qual se lê que "a indústria nacional não pode prescindir de uma sadia política de comércio exterior, tendente a pôr empresas instaladas para produção de artigos essenciais a coberto de surpresas resultantes de liberalidades excessivas em relação à concorrência externa"123. Em linha similar, criticou-se Dutra, em cujo governo teriam sido assumidos compromissos internacionais de liberação do comércio, sem se proceder "a um balanço dos resultados e à sua avaliação crítica em face dos objetivos permanentes de uma política comercial"124.

Diante de tal espírito, não surpreendem medidas como a promulgação dos Decretos n. 30.363 , de 1952, e 34.893, de 1954, que tornaram mais restritiva a remessa de lucros do capital estrangeiro (BASTOS, 2015, p. 372-373). A criação da Petrobrás, em 1953, que favorecia "um projeto de inscrição internacional de caráter autonômico" (HIRST, 1990, p. 20). Até mesmo o lançamento da Instrução n. 70 da SUMOC, de 1953, que, em detrimento da unificação e da liberdade dos mercados cambiais (princípios da ordem econômica ocidental), criava um sistema de taxas múltiplas e leilões cambiais (MALAN, 1995, p. 74).

Essas medidas ilustram, de maneira clara, a "resistência ao alinhamento". Afinal, estavam em confronto direto com o projeto liberal dos Estados Unidos. Foram os próprios

\footnotetext{
${ }^{122}$ CPDOC, GV c 1950.05.00/13.

${ }^{123}$ Biblioteca da Presidência, Mensagem ao Congresso, 1951, p. 128.

${ }^{124}$ Ibidem, p. 93.
} 
agentes diplomáticos norte-americanos que o disseram. O embaixador Herschel Johnson, por exemplo, informou: "we are greatly disturbed in Emb at implications decree limiting remittances of profits on fon [foreign] capital. It understatement to say it will discourage entry of private fon [foreign] capital" ${ }^{125}$. Em tom similar, o subsecretário de Estado Walter Smith registrou: "in Brazil [...] the outlook is increasingly unfavorable. The passage of the Petrobraz Bill, which virtually excludes foreign participation in Brazil's petroleum development, represents a backward step"126.

No âmbito político, por fim, também podem ser encontradas manifestações de resistência à "imposição do alinhamento". Assim, pôs-se fim à exigência do atestado de ideologia emitido pela política política para a homologação de candidatos em eleições sindicais. Adotou-se de uma política social mais ativa (DEVOTO; FAUSTO, 2004, p. 313-314). Ainda mais ilustrativa da resistência à "imposição do alinhamento" foi a nomeação do petebista João Goulart para o Ministério do Trabalho, escolha considerada por alguns autores como uma guinada de Getúlio para a esquerda (DEVOTO; FAUSTO, 2004, p. 313).

Essa era a interpretação nos Estados Unidos à época. Assim, por exemplo, em memorando ao Departamento de Estado, o encarregado de negócios Walter Walmsley informava que, com a reforma ministerial de 1953, Vargas dava uma chance a Goulart "de construir uma máquina política esquerdista, demagógica e ultranacionalista através da manipulação da classe operária"127. Similarmente, o National Intelligence Estimate de dezembro de 1953 alertava que Goulart estava tentando "build up a stronger, Peronist-type labor organization" e, além disso, que "his collaboration with Communists to further his objectives has enabled them to increase their influence" 128.

\subsubsection{Exercício do alinhamento}

A política externa do governo Vargas (1951-1954), no entanto, não foi caracterizada apenas por iniciativas que, em graus variados, demandavam revisões na dinâmica do

\footnotetext{
${ }^{125}$ FRUS, "Telegrama 832.131/1-552" (5 de janeiro de 1952).

${ }^{126}$ FRUS, "S/S-NSC files, lot 63 D 351, NSC 144 Series" (20 de novembro de 1953).

127 Memorando de Walmsley para o Departamento de Estado em 13.07.1953, Dept. of State Archives, 732.00/7-1353 (HIRST, 1990, p. 57).

${ }^{128}$ FRUS, "INR-NIE files, NIE-86" (4 de dezembro de 1953).
} 
relacionamento com os Estados Unidos - vertente negativa. Houve, igualmente, iniciativas que indicavam direção contrária: reforço do alinhamento aos Estados Unidos - vertente positiva da "imposição do alinhamento". Por essa razão, não se pode reduzir a política externa brasileira desse período à barganha nacionalista (VISENTINI, 1996).

Além disso, mesmo considerando-se apenas as iniciativas que corroboravam a ideia de barganha nacionalista (VISENTINI, 1996), há de se considerar, igualmente, que muitas dessas iniciativas não alcançaram êxito - ou recompensas, parafraseando Moura (1990). Elas, consequentemente, indicavam o pragmatismo impossível da política externa do governo Vargas (1951-954), conforme conceitual Mônica Hirst (1990). Como visto, isso ocorreu a despeito, mesmo, de um cenário interno de nacionalização da política, que seria propício a uma política externa mais autônoma (FONSECA, 2001).

Assim, é lícito concluir que a "imposição do alinhamento" também vigorou durante o governo Vargas (1951-1954). A vertente positiva ampara essa conclusão. Por isso, após a análise da resistência ao alinhamento, passa-se a investigar o exercício deste.

\subsubsection{Os chanceleres de Vargas}

No capítulo anterior, a análise das medidas que afirmaram o alinhamento do Brasil aos Estados Unidos durante o governo Dutra (1946-1950) foi iniciada pelo estudo dos perfis dos dois chanceleres desse período. Esse estudo demonstrou que tanto João Neves da Fontoura (PSD) quanto Raul Fernandes (UDN) eram fervorosos defensores, no discurso e na prática, da política externa alinhada aos norte-americanos.

Nesse sentido, Silva (1995, p. 108) caracterizou o primeiro chanceler como "típico representante do americanismo excessivamente ideológico", enquanto Lourenço Neto (2012) argumentou que a assunção do segundo chanceler implicou a intensificação do alinhamento. Diante desse quadro, não surpreende que Pinheiro (2004) tenha conceituado a política externa do governo Dutra (1946-1950) como americanismo ideológico; e Cervo (2008a), como alinhamento ideológico.

Prezando-se pela coerência analítica, investiga-se a política externa do governo Vargas também segundo o perfil dos chanceleres. Tal abordagem traz um ganho analítico significativo, pois poucos critérios seriam tão expressivamente eloquentes para testemunhar a 
continuidade da "imposição do alinhamento" na segunda passagem de Getúlio pelo Catete. Afinal, foi justamente João Neves da Fontoura - aquele "típico representante do americanismo excessivamente ideológico" (SILVA, 1995, p. 108) - o nome escolhido para estar à frente do Itamaraty, em 1951. A propósito, fazendo jus à caracterização de Silva (1995) quanto ao entusiasmo de João Neves na adoção do americanismo, o chanceler de Getúlio referia-se aos Estados Unidos como a "mais desenvolvida nação do mundo"129.

Da mesma forma, os dois chanceleres de Vargas apresentaram trajetória políticopartidária similar à dos dois chanceleres de Dutra. Em ambos os governos, escolheu-se um partidário do PSD (João Neves) inicialmente e, depois, um partidário/simpatizante da UDN (Raul Fernandes e Vicente Rao). Mais uma manifestação de continuidade entre a política externa dos dois governos, caracterizada pela "imposição do alinhamento".

Essa trajetória político-partidária similar sugere orientações ideológicas também semelhantes, notadamente em relação ao anticomunismo. Em João Neves da Fontoura, esse traço já foi analisado no capítulo anterior. Resta, então, apontá-lo em Vicente Rao.

Para tanto, basta lembrar de sua atuação política anterior junto a Getúlio Vargas, como ministro da Justiça entre 1935 e 1937. Nesse sentido, destaca-se a promulgação da Lei de Segurança Nacional de 1935, que considerava crimes contra a ordem política e social, por exemplo, a "propaganda subversiva" (FAUSTO, 2009, p. 359). Sua autoria, conforme lembra Paulo Sérgio Pinheiro (1991, p. 271) foi, sintomaticamente, de Raul Fernandes e Vicente Rao, posteriormente chanceleres do americanismo (PINHEIRO, 2004).

Assim, não surpreende que Pinheiro (1991, p. 220) considere Vicente Rao como "agente da consolidação e afirmação [...] da sagrada união contra o comunismo". Esses predicativos foram, inclusive, ecoados, explícita ou implicitamente, pelo próprio Vicente Rao em seu discurso de posse como ministro das Relações Exteriores, ao afirmar que "somos parte integrantes da comunhão das Nações formadas de povos livres, fiéis aos mais elevados princípios democráticos. [...] Defensores de nossa civilização cristã"130. Mensagem similar foi dada em sua homenagem ao Núncio Apostólico no Brasil, em novembro de 1953:

Nós não cremos nesse estranho e paradoxal materialismo, que procura edificar uma suposta fé, ou mística da matéria, querendo, através desta pouca cousa, explicar todos os fenômenos espirituais, toda a história da humanidade, todas as manifestações da mente humana.

\footnotetext{
${ }^{129}$ Relatório, 1951, p. 13.

${ }^{130}$ CPDOC, GV c 1953.05.00/4.
} 
[...] A nação brasileira nasceu sob o signo da Santa Cruz e a Igreja lhe acompanhou e acompanha a formação e o desenvolvimento.

[...] A história da Igreja no Brasil como que se confunde com a nossa própria história. Assim sucede, assim pode suceder, porque a Igreja, a par de seus ensinamentos espirituais, ministra o mais acendrado ensino cívico e que que o bom cristão também seja um bom patriota. ${ }^{131}$

De maneira ainda mais clara, foi também o próprio Vicente Rao que expôs seu anticomunismo:

Ou nós ou eles! Não há meio termo possível! Enquanto nós queremos a ordem jurídica, o regime da liberdade, não há, para eles, recurso em seus esforços diabólicos de destruição e anarquia! A violência, que nos causa sobressalto e horror, que violenta nossa consciência jurídica é para eles meio doutrinário e prático da vitória. ${ }^{132}$

Naturalmente, o anticomunismo era a outra face do americanismo, conforme analisado no capítulo anterior. Dessa forma, à expressão de críticas ao comunismo estavam relacionadas medidas de apoio aos Estados Unidos, reforçando a ideia da vertente positiva da "imposição do alinhamento" - e do pragmatismo impossivel (HIRST, 1990). Nesse aspecto, é ilustrativa a atitude de Vicente Rao no tocante à questão da Guatemala de Jacobo Arbenz, considerada comunista em virtude da tentativa de reforma agrária que afetava interesses econômicos norte-americanos no país (MENDONÇA, 1995, p. 59-60).

Rao, como ministro das Relações Exteriores, deu apoio à interpretação de que o governo Arbenz era comunista (DORATIOTO; VIDIGAL, 2014, p. 73). Assim, o Brasil subscreveu, na OEA, a resolução "Declaração de Solidariedade para a Preservação da Integridade dos Estados Americanos contra a Intervenção do Comunismo Internacional", que, patrocinada pelos Estados Unidos, pavimentava o caminho para uma intervenção destes na Guatemala (MARTINS, 2016, p. 3).

Além disso, o chanceler repreendeu o chefe da legação brasileira na Cidade da Guatemala Carlos da Silveira Martins Ramos. Este havia se solidarizado, publicamente, com o governo de Arbenz, enviando-lhe "integral simpatia e os mais ardentes votos pelo triunfo da causa da liberdade, da democracia, e da dignidade continental da Guatemala, em sua luta titânica contra as forças da tirania e do imperialismo"133. Diante da "inconveniência da atitude", Vicente Rao, adverti-o, solicitando-lhe que não reincidisse no "erro praticado". O alinhamento impunha-se.

\footnotetext{
${ }^{131}$ CPDOC, GV c 1953.11.16/2.

132 Vicente Rao (apud MENDONÇA, 1995, p. 67).

${ }^{133}$ CPDOC, GV c 1954.06.22/6.
} 
Verifica-se, assim, que a política externa alinhada não se restringiu ao governo Dutra (1946-1950), mas persistiu na década seguinte, a despeito do que seria de esperar-se do retorno de Vargas ao Catete e da nacionalização da política doméstica. A análise dos perfis dos chanceleres do período aponta a continuidade, no governo Vargas (1951-1954), de diretrizes político-ideológicas bastante similares às verificadas no governo Dutra (1946-1950). Houve, inclusive, a continuidade do próprio chanceler João Neves da Fontoura.

Com isso, é legítimo argumentar que a "imposição do alinhamento" também se manifestou na primeira metade da década de 1950. Nas próximas seções, serão analisadas outras manifestações da vertente positiva (exercício) do alinhamento, amparada sobre a ideia de pragmatismo impossivel (HIRST, 1990).

\subsubsection{Da regra geral para as medidas específicas}

A continuidade da "imposição do alinhamento", já sugerida pela continuidade dos chanceleres ou do perfil político-ideológico destes, pode ser verificada por meio da análise de medidas específicas. Assim, à semelhança do governo Dutra (1946-1950), no governo Vargas (1951-1954), iniciativas concretas nos âmbitos político e econômico também corroboraram a ideia da "imposição do alinhamento".

Antes, no entanto, de analisar essas medidas específicas, há de se fazer um registro quanto à "ilusão" política de Dutra. Conforme apresentado no capítulo anterior, a expectativa de que o Brasil, no pós-Segunda Guerra Mundial, teria "relações especiais" com os Estados Unidos é um dos elementos ressaltados pela literatura (BANDEIRA, 1973; BUENO; CERVO, 2012; VISENTINI, 2013b), ao se referir sobre a política externa desse governo. Essa expectativa, suposto sinal da inépcia política de Dutra, teria contribuído sobremaneira para a conformação do alinhamento brasileiro aos Estados Unidos.

Com vistas a manter a coerência, essa "ilusão" deveria ser ressaltada pela literatura, ao se referir, também, ao governo Vargas, atribuindo-lhe os mesmos predicativos - inépcia política, falta de leitura adequada das relações internacionais. Afinal, a mesma "ilusão" foi verificada no governo Vargas (1951-1954).

Assim, se a barganha nacionalista (VISENTINI, 1996) é depreendida na análise do secretário de Estado Dean Acheson de que "Vargas undoubtedly would make aggressive and 
persistent claims upon the United States for financial and other types of assistance"134, a "ilusão" política também o é. Afinal, na mesma análise, Acheson apresentou a justificativa para o pleito varguista: "in recognition of Brazil's contribution during the recent war and the generally held opinion that Brazil has a right to the position as the leading South American country, the United States' "traditional ally" [grifo dele]".

Em tom similar, o chanceler João Neves da Fontoura ponderou junto ao subsecretário de Estado Edward Miller: "eu não podia [...] deixar de mencionar que os Estados Unidos, depois de 1945, não cooperaram conosco, como era do interesse de ambos os países e como era natural depois do nosso esforço de guerra desde 1942"135. A "ilusão" política persistia.

Pode-se, mesmo, argumentar que nutrir tal "ilusão" seria ainda mais grave no governo Vargas. Afinal, já se haviam passado cinco anos sem que a expectativa de "aliança especial" se concretizasse. Ao longo desses anos, gradativamente, esse estado de ânimos foi alterandose (MALAN, 1995), levando à "reversão das expectativas no governo Dutra" (GARCIA, 2012, p. 286). Não à toa, no final desse governo, o Brasil manifestou sua insatisfação com os Estados Unidos por meio do Memorando da Frustração, de Raul Fernandes (MOURA, 1990).

Dessa forma, confirmava-se o que, já em 1947, Oswaldo Aranha havia antecipado a Raul Fernandes (GOMES, 2016). Em memorando ao chanceler, o então chefe da representação brasileira na ONU alertou: "a memória norte-americana é muito fraca, ou melhor, a necessidade e o interesse atuais fazem com que procurem esquecer a nossa solidariedade e os nossos sacrifícios"136, de modo que o Brasil não poderia, "por algum tempo, contar com este país" e que "seria cegueira pintar-lhe um quadro diferente".

De toda forma, argumenta-se, como feito no capítulo anterior, que mais razoável que condenar essa "ilusão" retrospectivamente é admiti-la como uma possibilidade plausível na época, em ambos os governos - ainda que, no governo Vargas, acreditar nela fosse mais difícil. O importante, acima de tudo, é manter a coerência analítica, e não condenar essa expectativa em Dutra, mas negligenciá-la em Vargas, como é feito muitas vezes.

Isso posto, passa-se a analisar medidas específicas que atestaram o alinhamento brasileiro ao Estados Unidos. Assim, no âmbito político, a "imposição alinhamento" foi

\footnotetext{
${ }^{134}$ FRUS, "Memorando 611.35/5-150" (01 de maio de 1950).

${ }^{135}$ CPDOC, GV c 1951.02.19/1.

${ }^{136}$ CPDOC, OA cp 1947.03.18.
} 
verificada na IV Reunião de Consulta dos Chanceleres Americanos, que, como visto, também foi palco para a barganha nacionalista (VISENTINI, 1996). Afinal, nela, também se afirmou "o apoio das Repúblicas americanas à ação das Nações unidas para reprimir a agressão soviética na Coreia e em qualquer outro ponto onde ela se manifeste" ${ }^{137}$. Ao subscrever essa resolução, o Brasil reafirmava sua filiação ao bloco ocidental, no mesmo palco em que tentava reeditar a barganha nacionalista (VISENTINI, 1996), uma situação aparentemente contraditória, mas que corresponde às duas vertentes da "imposição do alinhamento".

Igualmente ilustrativa foi a compra de centrífugas para enriquecimento de urânio. $\mathrm{O}$ acordo foi firmado entre a empresa Sertorious Werk $A G$, da República Federal da Alemanha, e o presidente do recém-criado Conselho Nacional de Pesquisa $(\mathrm{CNPq})$, almirante Álvaro Alberto (ANDRADE; SANTOS, 2013). "No entanto, antes que os três protótipos para enriquecimento de urânio fossem embarcados no porto de Hamburgo com destino ao Rio de Janeiro, o Military Board of Security, dos EUA, apreendeu o carregamento" (ANDRADE; SANTOS, 2013, p. 124). Em consequência, o Brasil não chegou a receber a encomenda. O alinhamento impunha-se, e sem recompensas.

$\mathrm{O}$ mesmo pode-se dizer em relação ao ensaio de um novo Pacto $\mathrm{ABC}$, discutido em segredo entre Vargas e Perón. Essa cooperação, ensaiada desde a campanha presidencial de 1950, viu-se inviabilizada pelo "clamor liberal" do período. É verdade que, na literatura, há diferentes interpretações acerca do significado desse "clamor liberal" no caso concreto.

Assim, por exemplo, Reckziegel (2007) argumenta que o Pacto ABC foi bloqueado porque contrariava a noção de sistema continental defendida pelos Estados Unidos e por causa da significativa rivalidade social da política doméstica. Hirst (1990, p. 35) aponta que o governo argentino considerava culpados o Parlamento, a imprensa e o Itamaraty, eximindo Vargas de qualquer responsabilidade pelo bloqueio da aproximação bilateral. Bandeira (2003, p. 258-261), a seu turno, ressalta que o peronismo contrariava o sistema pan-americano defendido pelos chanceleres João Neves da Fontoura e Vicente Rao, pelos setores dominantes das Forças Armadas, pela imprensa conservadora e pela UDN. Fausto (2009) chama atenção para a forma como o Pacto ABC veio a público: denunciado, em 1954, pelo ex-chanceler João Neves da Fontoura como uma tentativa de afastar o Brasil dos Estados Unidos e de instalar uma república sindicalista, nos moldes argentinos.

${ }^{137}$ Relatório, 1951, p. 12. 
De toda forma, independentemente de seu significado, o "clamor liberal" - alimentado por forças externa e internas - bloqueou qualquer possibilidade de um novo Pacto $\mathrm{ABC}$ se concretizar. Isso ilustra a limitação da margem de manobra do Brasil no cenário internacional e, consequentemente, o exercício da "imposição do alinhamento".

Ainda no âmbito política, esse exercício do alinhamento também é ilustrado pela instalação da embaixada brasileira em Taipé, em abril de 1953 (GARCIA, 2005, p. 171). Com isso, Vargas (1951-1954) dava continuidade à orientação adotada no governo Dutra (1946-1950) e declarava manter relações diplomáticas com a China nacionalista, considerada, no entanto, "uma ficção da diplomacia norte-americana" ${ }^{138}$ por Oswaldo Aranha.

No âmbito militar, as manifestações mais ilustrativas do exercício do alinhamento (vertente positiva) foram o Tratado de Assistência Militar, de 1952, e o Acordo Militar, de 1953. Por duas razões principais, esses instrumentos endossam a ideia de "imposição do alinhamento". A primeira razão é o fato de eles atestaram, explicitamente, a filiação do Brasil de Vargas ao sistema de defesa dos Estados Unidos, em manifesta demonstração de alinhamento. Afinal, conforme ressaltado por Laufer e Rapoport (2000, p. 76), o Tratado "atribuía ao exército norte-americano direitos exclusivos para colaborar na organização e operação da Escola Superior de Guerra" - e, consequentemente, na formação ideológica da alta oficialidade brasileira.

A segunda razão, por sua vez, refere-se ao alinhamento sem recompensas (MOURA, 1990) da política externa também do governo Vargas (1951-1954), e não apenas do governo Dutra (1946-1950), para o qual o conceito de Moura (1990) foi cunhado. Nesse sentido, no contexto da guerra da Coreia, tentava-se reeditar uma política de barganhas (VISENTINI, 1996), associando concessões brasileiras no âmbito militar a investimentos norte-americanos no âmbito produtivo.

Os acordos militares, contudo, demonstraram que a política externa do governo Vargas foi marcada por um pragmatismo impossível (HIRST, 1990). Afinal, os Estados Unidos dissociaram os âmbitos securitário e desenvolvimentista, com a assinatura de compromissos estritamente militares. Assim, houve as concessões brasileiras no âmbito militar, mas elas não foram retribuídas em termos de cooperação econômica. A derrota da estratégia varguista significou um duro golpe ao projeto nacional-desenvolvimentista (HIRST, 1990; 
DORATIOTO; VIDIGAL, 2014), levando, inclusive, ao pedido de demissão do ministro da Guerra, Estillac Leal.

A falta de recompensas no governo Vargas (1951-1954) também é demonstrada pela extinção unilateral pelos Estados Unidos da CMBEU, em dezembro de 1953. Como visto, a Comissão era identificada como o meio para efetivar a barganha nacionalista (VISENTINI, 1996). Simbolizava, caso exitosa, uma alteração na dimensão do relacionamento bilateral Brasil - Estados Unidos. A CMBEU, todavia, apresentou profundas dificuldades em converter seus projetos em realizações, notadamente devido à "baixa disponibilidade de recursos financeiros do organismos norte-americanos" e às "divergências intraburocráticas da administração Truman" (HIRST, 1990, p. 15).

Com a chegada à Casa Branca do republicano que pôs fim às duas décadas de governo democrata, Dwight Eisenhower, os Estados Unidos extinguiram a Comissão Mista. Seu fechamento implicou, segundo Bueno e Cervo (2012, p. 300), o sepultamento definitivo do "mito do relacionamento especial". O novo secretário de Estado, John Foster Dulles, não poderia ser mais claro nesse sentido:

Continuation Joint Commission will not improve prospects finance projects. [...] Brazilians believe existence Commission will help obtain commitments from banks or shift balance program financing to Eximbank or Treasury. Should be made clear Foreign Minister neither possibility exists.

Past misunderstandings and present impasse are result repeated unsuccessful attempts place financing on basis advance Bank commitments, specified conditions. Also public statements have created misunderstandings regarding financial commitments. Continuation this basis would lead to further frustrations. ${ }^{139}$

O alinhamento se impunha, e sem recompensas. Assim, como caracterizou Hirst (1990), o governo Vargas foi uma época em que o pragmatismo era impossível - do mesmo modo que o fora o governo Dutra. Foi uma época de "imposição do alinhamento".

\subsection{Conclusões parciais}

O objeto de estudo do presente capítulo foi a política externa do governo Vargas (1951-1954). Nesse sentido, argumentou-se que o quadro de "imposição do alinhamento" também foi verificado entre os anos 1951 e 1954, período da segunda passagem de Vargas pelo Catete - pela primeira vez por meio do voto popular.

${ }^{139}$ FRUS, "Telegrama 832.00 TA/5-653" (08 de maio de 1953). 
A aplicação desse conceito à política externa varguista parece contrariar caracterizações como a de Visentini (1996), segundo a qual o governo Vargas (1951-1954) seria identificado pela barganha nacionalista. Caracterização esta que é endossada por outros autores, como Amado Cervo (2007, 2008a) e Moniz Bandeira (1973, 2003).

Argumentou-se, no entanto, que a ideia de barganha nacionalista (VISENTINI, 1996) apreende não a totalidade da política externa do governo Vargas (1951-1954), mas sua metade. Segundo a tipologia aplicada neste trabalho, a barganha nacionalista (VISENTINI, 1996) é bastante útil para caracterizar a vertente negativa da imposição - em outros termos, manifestações, em graus variados, de resistência ao alinhamento.

Essas manifestações decorreram tanto de fatores internos quanto externos. Quanto aos primeiros, exerceram influência o próprio retorno de Vargas e a nacionalização da política brasileira, resultante das eleições de 1950. Tal configuração, conforme argumenta Gelson Fonseca (2001), sugeriria maior pressão por uma inserção internacional mais autônoma. Em relação aos fatores externos, contribuíram a emergência de novos polos de poder, a onda nacionalista que se verificava no período e a relativa distensão entre as superpotências característica do antagonismo oscilatório (HALLIDAY, 1986).

Apesar disso, não se pode caracterizara política externa do governo Vargas como barganha nacionalista (VISENTINI, 1996), sob pena de se definir o todo pela parte. Afinal, o mesmo governo também foi caracterizado pelo pragmatismo impossível (HIRST, 1990), conforme apreendido pela vertente positiva do alinhamento.

Nesse sentido, a despeito daquelas forças, como a nacionalização da política brasileira, o alinhamento continuou a se impôr, da mesma forma que durante o governo Dutra (1946-1950). Sintomaticamente, o primeiro e mais longevo chanceler de Vargas (1951-1954) foi João Neves da Fontoura, o "típico representante do americanismo excessivamente ideológico" (SILVA, 1995, p. 108) do governo anterior, considerado entreguista (VISENTINI, 2013b). A Fontoura seguiu-se, também de maneira sintomática, Vicente Rao, político simpatizante da UDN e, como tal, anticomunista (PINHEIRO, 1991) e americanista (PINHEIRO, 2004).

Inclusive, os chanceleres de Vargas apresentaram a mesma sequência políticoideológica verificada no governo Dutra: um partidário do PSD, seguido por um udenista. Não surpreende, assim, que Doratioto e Vidigal (2014, p. 71) argumentem que a política externa 
do segundo governo Vargas (1951-1954) se assemelhou mais à do governo Dutra (1946-1950) que à do primeiro governo Vargas (1930-1945).

Essa semelhança foi verificada, inclusive, na "ilusão" quanto à suposta aliança especial com os Estados Unidos. Curiosamente, na literatura, encontram-se mais críticas a essa "ilusão" pelo governo Dutra, quando se era muito mais plausível supor tal relacionamento; que pelo governo Vargas, quando já se haviam transcorrido cinco anos de alinhamento sem recompensas (MOURA, 1990).

Uma eventual explicação para isso é a tendência, conforme argumentado ao longo deste trabalho, de se analisar a política externa do segundo governo Vargas (1951-1954) com chaves analíticas próprias ao primeiro (1930-1945). Não considerando, assim, que os contextos doméstico e internacional haviam se transformado significativamente ao longo desse período, conforme apontado no primeiro capítulo.

Nesse sentido, o conceito de "imposição do alinhamento" é uma tentativa de se analisar o segundo governo Vargas (1951-1954) em si, sem relação com o primeiro (1930-1945). Além disso, o conceito é um esforço analítico abrangente, de modo a compreender múltiplas faces da política externa desse governo, polarizada entre barganha nacionalista (VISENTINI, 1996) e pragmatismo impossível (HIRST, 1990).

Em consequência, por meio da ideia de "imposição do alinhamento", procurou-se demonstrar que, da mesma forma que durante o governo Dutra (1946-1950), durante o governo Vargas (1951-1954), não havia nem viabilidade nacional, nem permissibilidade internacional (JAGUARIBE, 1976) para uma política externa mais autônoma. Assim, a despeito de forças em sentido contrário, como a nacionalização da política brasileira, o alinhamento impôs-se 


\section{CONCLUSÃO}

A análise de elementos dos contextos internacional e nacional entre os anos finais do primeiro (1930-1945) e do segundo governo Vargas (1951-1954) permite argumentar que a política externa brasileira desse período foi caracterizada pela "imposição do alinhamento". Assim, tanto o governo de Eurico Dutra (1946-1950) quanto o de Getúlio Vargas (1951-1954) viram-se diante de um "clamor liberal" que, alimentado por forças domésticas e externas, pautou a orientação política do Brasil.

Tal "clamor liberal" foi gestado antes mesmo desses dois governos. Foi produto das transformações por que passavam o mundo e o Brasil na década de 1940. No plano internacional, essas transformações foram, essencialmente, a vitória das forças Aliadas na Segunda Guerra Mundial, a decadência das antigas potências europeias, a emergência das duas superpotências mundiais e, posteriormente, a conformação da Guerra Fria. Diante disso, os Estados Unidos constituíram-se como a principal referência para o mundo ocidental, que, dessa forma, seria influenciado pelo arcabouço político-ideológico norte-americano. O liberalismo - retórico ou efetivo - era a essência desse arcabouço.

No plano nacional, a seu turno, acumulava-se a insatisfação em relação ao governo Vargas (1930-1945), mesmo entre quem se havia beneficiado durante seu mandato. Para tanto, pesava a significativa amplitude temporal de sua gestão - quase 15 anos -, o que tenderia a desgastar qualquer governo. Em acréscimo a esse desgate natural, influía o fato de que o país estava sob um regime de exceção desde, pelo menos, 1937, quando se instituiu o Estado Novo. Havia, assim, um ambiente repressivo e autoritário, contra o qual oposição e dissidentes varguistas se insurgiam.

Esse grupo ganhou fôlego com a participação brasileira na Segunda Guerra Mundial junto às forças Aliadas. Afinal, essa adesão lançava o Brasil em uma profunda contradição entre governo e Estado. Por um lado, o Estado (República dos Estados Unidos do Brasil) colocava-se ao lado das forças - autoproclamadas - liberais, que saíram vencedoras da guerra; por outro, o governo (presidência de Vargas) estava associado às forças - identificadas como - autoritárias, que foram derrotadas.

Juntas, a insatisfação com o governo Vargas e a contradição entre Estado e governo brasileiros culminaram na convocação, em maio de 1945, de eleições gerais e na deposição, 
em outubro do mesmo ano, de Getúlio Vargas. Com isso, haveria de nascer um novo regime político e um novo governo no Brasil, cujo fundamento seriam uma referência negativa (o autoritarismo do período anterior) e uma referência positiva (o liberalismo à brasileira, em diversas frentes e em graus variados).

Assim, diante dos contextos internacional e nacional, o "clamor liberal" era uma força que se colocava sobre o governo (e o regime) que assumiria o Brasil em 1946, de modo praticamente independente de quem ocupasse o cargo de Presidente da República. Pode-se argumentar que o liberalismo se impunha, conforme ilustram os programas dos principais partidos políticos que disputaram as eleições de dezembro de 1945.

Sob o impulso do "clamor liberal", elegeu-se um Congresso Nacional e formularam-se medidas nos âmbitos político e econômico e mesmo uma Constituição Federal. Na política externa, isso traduziu-se em alinhamento aos Estados Unidos, país que encarnava - na prática ou na retórica - os valores liberais. Assim, a República Liberal-Conservadora (1946-1964) nasceu sob a influência inescapável do liberalismo (à brasileira).

A magnitude do "clamor liberal" foi tão intensa que, sintomaticamente, a política externa alinhada se operou justamente durante o governo de um general do Exército que fora ex-ministro da Guerra de Vargas e que se distinguia por ser simpatizante dos países do Eixo e antipático aos Estados Unidos. Tal aparente paradoxo explica-se, naturalmente, por seu contexto, caracterizado pela "imposição do alinhamento".

Em testemunho dessa imposição, até as antigas potências europeias que haviam exercido hegemonia individual ou coletivamente sobre as relações internacionais por quatro séculos alinharam-se aos Estados Unidos no pós-1945. Assim, a França rebaixou-se à posição de "pedinte", como descrevera Georges Bidault; o Reino Unido decaiu de banco do mundo para mutuário dos Estados Unidos; a Alemanha e a Áustria tiveram seus territórios ocupados. Diante de tal cenário, a "imposição do alinhamento" sobre o Brasil foi reforçada, pois diminuíram as opções para o país, em termos de cooperação e comércio internacionais.

O mesmo resultado adveio da consolidação da Guerra Fria, uma vez que a disputa ideológica - que não se furtava em recorrer a dinheiro e armas - também reforçou a "imposição do alinhamento". A divisão bipolar do mundo restringia as possibilidades brasileiras de cooperação e comércio com Estados comunistas. A América Latina, nessa divisão, era considerada domínio por excelência dos norte-americanos, que não hesitavam em 
exercer seu poder na região. A ampla rede de instituições fundadas em torno de uma nova e mais difusa forma de liberalismo naturalizou valores, objetivos e princípios norte-americanos, ao ponto de confundi-los com a própria noção de Ocidente, modernidade, progresso.

A "imposição do alinhamento", no entanto, também decorria, como dito, de interesses brasileiros. Nesse sentido, o anticomunismo era um sentimento profundo e difundido na sociedade nacional. Era, inclusive, instrumentalizado por elites políticas conservadoras, que rotulavam manifestações de insatisfação e reivindicação social como comunistas, reprimindoas. Em oposição, o americanismo era um sentimento integrante da tradição histórico-cultural da República brasileira. Ainda, havia a expectativa, razoável à época, de que o país teria "relações especiais" com os Estados Unidos no pós-guerra, o que se traduziria em auxílio norte-americano no desenvolvimento econômico brasileiro.

Esse quadro geral de alinhamento aplicou-se tanto ao governo Dutra (1946-1950) quanto ao Vargas (1951-1954), pois, em ambos, a política externa esteve associada aos Estados Unidos, em decorrência das razões expostas. O próprio perfil dos chanceleres escolhidos pelos dois presidentes sugere-o. Nesse sentido, houve, inclusive, coincidência quanto ao personagem, pois João Neves da Fontoura, identificado como grande entusiasta do americanismo, esteve à frente do Itamaraty em ambos os governos. Um sinal claro de continuidade, assim como o fato de que, nos dois casos, a João Neves sucedeu um udenista: Raul Fernandes, com Dutra (1946-1950); Vicente Rao, com Vargas (1951-1954).

Além do perfil dos chanceleres, outros elementos revelam o alinhamento nos dois governos. Associação militar: a criação do Estado-Maior das Forças Armadas e da Escola Superior de Guerra em moldes norte-americanos, a celebração do Acordo Militar de 1953. Filiação política: endosso às propostas de interesse dos Estados Unidos na ONU, ruptura de relações diplomáticas com a República Popular da China e posterior instalação de embaixada brasileira em Taipei. Medidas econômicas: liberalização da remessa de lucros.

Em conjunto, esse cenário faz mais que apontar a política externa alinhada nos dois governos. Nomeadamente, ele endossa a ideia de "imposição do alinhamento". Afinal, o alinhamento manifestou-se, por fatores internos e externos, independentemente de quem ocupasse o Catete. Assim, a política externa alinhada foi implementada por Dutra, comumente associado a predicativos como subserviente, entreguista, liberal; e também por Vargas, frequentemente identificado como negociador, autonomista, nacionalista. 
Em consequência, como o alinhamento ao Estados Unidos se verificou em governos cujos presidentes apresentavam perfis tão distintos - ou, mesmo, opostos -, isso indica que não foi o perfil do presidente que levou à política externa alinhada. Independentemente do presidente, o alinhamento ter-se-ia imposto.

Essa conclusão é ainda reforçada pelo fato de que o alinhamento se teria colocado não apenas independentemente, mas também a despeito do presidente. Assim, tanto Dutra (1946-1950) quanto Vargas (1951-1954) adotaram medidas que, em graus variados, contrariavam a expectativa, os preceitos ou a postura norte-americanos.

No âmbito econômico, por exemplo, foram adotadas restrições na circulação de divisas, estabelecidos controles sobre o câmbio e sobre a remessa de lucros, praticadas intervenções estatais na economia, impostas restrições à participação do capital estrangeiro na exploração de determinadas atividades. Essas medidas estavam em franco contraste com o liberalismo que fundamentava a ordem econômica ocidental e com os interesses estadunidenses.

Além disso, ambos os governos implementaram iniciativas que protegiam, desenvolviam ou estimulavam a indústria nacional. Essas medidas também podem ser interpretadas como estando em contraste com os interesses norte-americanos. Afinal, o retorno a uma suposta vocação agrícola brasileira é, não raramente, apontado como consequência imediata de uma política alinhada aos Estados Unidos.

Ainda, os dois presidentes reiteradamente demandaram uma revisão na dinâmica do relacionamento bilateral com os Estados Unidos. Assim, pleitearam insistente e incisivamente recursos públicos norte-americanos para o financiamento de projetos de desenvolvimento nacional do Brasil.

No âmbito político, igualmente, Dutra e Vargas implementaram ações que colocaram Washington e Rio de Janeiro em lados distintos. Assim, enquanto o Brasil rompeu relações diplomáticas com a União Soviética, os Estados Unidos não apenas não tomaram medida semelhante, como também tentaram impedir o Brasil de fazê-lo. Rio de Janeiro recusou o envio de tropas militares para a Guerra da Coreia, a despeito de pedidos norte-americanos e da ONU. O Brasil elaborou uma visão própria de segurança que, se não contrastava com a norte-americana, lhe era concorrente na disputa por corações e mentes latino-americanos. 
Mesmo diante de eventuais aberturas nos cenários internacional e nacional, argumenta-se que o alinhamento seguiu vigente. Assim, a política externa alinhada continuou a ser adotada quando a Guerra Fria teve momentos de relativa flexibilidade; quando surgiram novos polos de poder, o que oferecia ao país mais oportunidades de comércio e cooperação internacionais; quando se manifestaram ondas nacionalistas no Brasil e no mundo. A despeito de elementos como esses, que sugeririam uma política externa mais autonomista, verificou-se a "imposição do alinhamento" - reforçando, assim, o caráter impositivo.

Assim, ao captar essas nuances, contradições e complexidades, a ideia de "imposição do alinhamento" oferece uma chave analítica útil para se procurar compreender a política externa brasileira entre 1946 e 1954. Permite, por meio da identificação de comportamentos que endossam e que refutam o alinhamento, categorizar a política externa dos governos Dutra (1946-1950) e Vargas (1951-1954) sem simplificações maniqueístas, dicotômicas.

Valendo-se dos conceitos tradicionalmente utilizados para a interpretação do período, a ideia de "imposição do alinhamento" esforça-se por incorporar as produções já existentes, intentando complementar-lhes. Nesse sentido, uma das principais contribuições advindas do esforço de elaboração do conceito de "imposição do alinhamento" foi a reiteração da necessidade de se analisar a história historicamente. Em outros termos, ressaltou-se a óbvia importância de se interpretar a política externa dos governos Dutra (1946-1950) e Vargas (1951-1954) segundo os elementos que se punham a eles na época, evitando - ou esforçandose por evitar - a análise retrospectiva.

Por fim, independentemente de qualquer outro eventual significado, o conceito de "imposição do alinhamento" tem um valor pedagógico. Afinal, é um testemunho de que as interpretações clássicas, já consagradas, devem ser revisitadas, e não apenas meramente reproduzidas. O benefício de tal esforço é garantido de início, qualquer que seja o resultado posterior. Caso os clássicos se confirmem, eles são fortalecidos; caso sejam relativizados, avança-se o conhecimento científico. É nesse sentido, acima de tudo, que se justifica o esforço analítico do conceito de "imposição do alinhamento" 


\section{BIBLIOGRAFIA}

ABREU, Marcelo de Paiva. O processo econômico. In: GOMES, Angela de Castro. Olhando para dentro (1930-1964). Madrid/Rio de Janeiro: Fundación Mapfre/Objetiva, 2013, p. $179-228$.

ABREU, Marcelo de Paiva. Crise, crescimento e modernização autoritária, 1930-1945. In: ABREU, Marcelo de Paiva (org.). A ordem do progresso: dois séculos de política econômica no Brasil. 2. ed. Rio de Janeiro: Elsevier, 2014, p. 79-104.

ACHARYA, Amitav; BUZAN, Barry. Why is there no non-Western international relations theory? An introduction. In: ACHARYA, Amitav; BUZAN, Barry (ed.). Non-Western international relations theory. London: Routledge, 2010, p. 1-25.

ALBUQUERQUE, José Augusto Guilhon (org.). Sessenta anos de política externa brasileira (1930-1990). 4v. São Paulo: Núcleo de Pesquisa em Relações Internacionais da Universidade de São Paulo/Cultura Editores Associados, 1996.

ALENCASTRE, Amílcar. Oswaldo Aranha, o mundo afro-asiático e a paz. Rio de Janeiro: Gráfica Editora Nap, 1961.

ALMEIDA, Paulo Roberto de. A diplomacia do liberalismo econômico. In: ALBUQUERQUE, José Augusto Guilhon (org.). Sessenta anos de política externa brasileira (1930-1990). São Paulo: Núcleo de Pesquisa em Relações Internacionais da Universidade de São Paulo/Cultura Editores Associados, 1996, v. 1, p. 173-210.

ANDRADE, Ana; SANTOS, Tatiane. A dinâmica da política de criação da Comissão Nacional de Energia Nuclear, 1956-1960. Boletim do Museu Paraense Emílio Goeldi Ciências Humanas, v. 8, n. 1, p. 113-128, 2013.

ALTEMANI, Henrique. Política externa brasileira. São Paulo: Saraiva, 2005.

ARAGON, Daniel. Chancellery sepulchers: Jânio Quadros, João Goulart and the Forging of Brazilian foreign policy in Angola, Mozambique, and South Africa, 1961-1964. LusoBrazilian Review, v. 47, n. 1, p. 121-149, 2010.

ARON, Raymond. Le grand schime. Paris: Gallimard, 1948.

AZZI, Riolando. O episcopado brasileiro frente à Revolução de 1930. Síntese, v. 5, n. 12, p. 47-78, 1978.

BANDEIRA, Luiz Alberto Moniz. Presença dos Estados Unidos no Brasil. Rio de Janeiro: Civilização Brasileira, 1973. 
BANDEIRA, Luiz Alberto Muniz. Brasil, Argentina e Estados Unidos - conflito e integração na América do Sul: da Tríplice Aliança ao Mercosul 1870-2003. Rio de Janeiro: Revan, 2003.

BARBOSA, Antônio José. Parlamento, política externa e o Golpe de 1964. In: MARTINS, Estevão de Rezende (org.). Relações Internacionais: visões do Brasil e da América Latina. Brasília: IBRI, 2003, p. 249-274.

BASTOS, Pedro Paulo Zahluth. O presidente desiludido: a campanha liberal e o pêndulo de política econômica no governo Dutra (1942-1948). História Econômica \& História de Empresas, v. 7, n. 1, p. 99-135, 2004.

BASTOS, Pedro Paulo Zahluth. Desenvolvimentismo, restrição externa e política econômica no segundo governo Vargas (1951-1954). História Econômica \& História de Empresas, v. 18, n. 2, p. 355-387, 2015.

BAYLIS, John; OWENS, Patricia; SMITH, Steve. Introduction. In: BAYLIS, John; OWENS, Patricia; SMITH, Steve (org.). The globalization of world politics: an introduction to international relations. 4. ed. New York: Oxford University, 2008, p. 1-13.

BETHELL, Leslie; ROXBOROUGH, Ian. The impact of the Cold War on Latin America. In: LEFFLER, Melvyn; PAINTER, David. The origins of the Cold War: an international history. 2. ed. New York and London: Routledge, 2005, p. 299-316.

BOBBIO, Noberto; MATTEUCCI, Nicola; PASQUINO, Gianfranco. Dicionário de política. 2v. Brasília: Universidade de Brasília, 1998.

BRADLEY, Mark Philip. Decolonization, the global South, and the Cold War, 1912-1962. In: LEFFLER, Melvyn; WESTAD, Odd (ed.). The Cambridge history of the Cold War. v. 1, Cambridge: Cambridge University, 2010, p. 464-486.

BUENO, Clodoaldo; CERVO, Amado. História da política exterior do Brasil. 4. ed. rev. ampl., $1^{\text {a }}$ reimpressão. Brasília: Universidade de Brasília, 2012.

BULL, Hedley. A sociedade anárquica. Brasília: Universidade de Brasília, Instituto de Pesquisa de Relações Internacionais, 2002.

BURNS, Bradford. A aliança não escrita: o Barão do Rio Branco e as relações BrasilEstados Unidos. Rio de Janeiro: EMC, 2003.

BURNS, Edward; LERNER, Robert; MEACHAM, Standish. História da civilização ocidental: do homem das cavernas às naves espaciais. 43. ed. São Paulo: Globo, v. 2, 2005.

CARONE, Edgar. A luta contra o Estado Novo. Revista Perspectivas, v. 2, p. 97-112, 1977. 
CARR, Edward. Vinte anos de crise, 1919 - 1939: uma introdução ao estudo das relações internacionais. 2. ed. Brasília: Universidade de Brasília, Instituto de Pesquisas de Relações Internacionais, 2001.

CATTAI, Júlio Barnez Pignata. O estandarte silencioso: a United States Information Agency na mídia impressa do Brasil - Correio da Manhã e Tribuna da Imprensa, 1953-1964. Dissertação de Mestrado. Universidade de São Paulo - Programa de Pós-Graduação em História. São Paulo, 2011.

CERVO, Amado. Relações internacionais do Brasil. In: CERVO, AMADO (org.). O desafio internacional: a política exterior do Brasil de 1930 a nossos dias. Brasília: Universidade de Brasília, 1994, p. 9-58.

CERVO, Amado. Relações internacionais da América Latina: velhos e novos paradigmas. 2. ed. São Paulo: Saraiva, 2007.

CERVO, Amado. Inserção internacional: formação dos conceitos brasileiros. São Paulo: Saraiva, 2008a.

CERVO, Amado. Hegemonia coletiva e equilíbrio: a construção do mundo liberal (1815-1971). In: SARAIVA, José Flávio Sombra (org.). História das relações internacionais contemporâneas: da sociedade internacional do século XIX à era da globalização. São Paulo: Saraiva, 2008b, p. 41-76.

CERVO, Amado. A instabilidade internacional (1919-1939). In: SARAIVA, José Flávio Sombra (org.). História das relações internacionais contemporâneas: da sociedade internacional do século XIX à era da globalização. São Paulo: Saraiva, 2008c, p. 131-168.

CHURCHILL, Winston Spencer. Never give in! The best of Winston Churchill's speeches selected and edited by his grandson. London: Pimlico, 2003.

CHACON, Vamireh. História dos partidos brasileiros: discurso e práxis dos seus programas. 3. ed. Brasília: Universidade de Brasília, 1998.

CLARK, Ian. Legitimacy in international society. Oxford: Oxford University, 2005.

CONFERENCIA DAS CLASSES PRODUTORAS DO BRASIL. Carta econômica de Teresópolis. Rio de Janeiro: Mauá, 1945.

CORRÊA, Luiz Felipe Seixas (Org.). O Brasil nas Nações Unidas: 1946 - 2006. Brasília: Fundação Alexandre de Gusmão, 2007.

CORTEZ, Ana Cláudia; LOBO, Carlos Eduardo. O programa "Guerra nas Estrelas" e o governo Reagan. In: CADUS - Revista de História, Política e Cultura, v. 1, n. 1, p. 39-50, 2015. 
CRUZ, José Humberto de Brito. Aspectos da evolução da diplomacia brasileira no período da política externa independente. Cadernos do IPRI, Brasília, n. 2, p. 65-78, 1989.

DALIO, Danilo; MIYAMOTO, Shiguenoli. O Brasil e a Conferência de Washington (1951). História, v. 28, n. 2, p. 57-78, 2009.

DANTAS, San Tiago. Política externa independente. Brasília: Fundação Alexandre de Gusmão, 2011.

DAM, Kenneth. Cordell Hul, the Reciprocal Trade Agreements Act, and the WTO. In: PETERSMANN, Ernst-Ulrich (ed.). Reforming the world trade system: legitimacy, efficiency, and democratic governance. Oxford: Oxford University, 2005, p. 83-97.

DELGADO, Marcio. O "golpismo democrático": Carlos Lacerda e o jornal Tribuna da Imprensa na queda da legalidade (1949-1964). Dissertação de Mestrado. Universidade Federal de Juiz de Fora - Programa de Pós-Graduação em História. Juiz de Fora, 2006.

DEVOTO, Fernando; FAUSTO, Boris. Brasil e Argentina: um ensaio de história comparada. São Paulo: 34, 2004.

DÖPCKE, Wolfgan. Apogeu e colapso do sistema internacional europeu. In: SARAIVA, José Flávio Sombra (org.). História das relações internacionais contemporâneas: da sociedade internacional do século XIX à era da globalização. São Paulo: Saraiva, 2008, p. 77-130.

DUROSELLE, Jean-Baptiste. Todo império perecerá: teoria das relações internacionais. Brasília: Universidade de Brasília; São Paulo: Imprensa Oficial do Estado, 2000.

DUROSELLE, Jean-Baptiste; RENOUVIN, Pierre. Introdução à história das relações internacionais. São Paulo: EDIPE, 1967.

ENGERMAN, David. Ideology and the origins of the Cold War, 1917-1962. In: LEFFLER, Melvyn; WESTAD, Odd (ed.). The Cambridge history of the Cold War. v. 1, Cambridge: Cambridge University, 2010, p. 20-43.

FAUSTO, Boris. O Estado Novo no contexto internacional. In: PANDOLFI, Dulve (org.). Repensando o Estado Novo. Rio de Janeiro: Fundação Getúlio Vargas, 1999, p. 17-20.

FAUSTO, Boris. História do Brasil. 13. ed. São Paulo: Universidade de São Paulo, 2009.

FAUSTO, Boris. A vida política. In: GOMES, Angela de Castro. Olhando para dentro (1930-1964). Madrid / Rio de Janeiro: Fundación Mapfre / Objetiva, 2013, p. 91-142.

FERGUSON, Niall. The cash nexus: money and power in the modern world, 1700-2000. New York: Basic Books, 2001. 
FERNANDES, Ananda. A reformulação da Doutrina de Segurança Nacional pela Escola Superior de Guerra no Brasil: a geopolítica de Golbery do Couto e Silva. Antíteses, v. 2, n. 4, p. 831-856, 2009.

FERNANDES, Pádua. Setenta anos após 1937: Francisco Campos, o Estado Novo e o pensamento jurídico autoritário. Prisma Jurídico, São Paulo, n. 6, p. 351-370, 2007.

FERNANDES, Raul. Nonagésimo aniversário: conferências e trabalhos esparsos. v. 1. Rio de Janeiro: Ministério das Relações Exteriores, 1967.

FERREIRA, Jorge. Crises da República: 1954, 1955 e 1961. In: FERREIRA, Jorge; DELGADO, Lucília (orgs.). O Brasil republicano: o tempo da experiência democrática (da democratização de 1945 ao golpe civil-militar de 1964). Rio de Janeiro: Civilização Brasileira, 2003, p. 301-342.

FERREIRA, Jorge. Apresentação. Tempo. v. 14, n. 28, p. 11-18, 2010.

FERREIRA, Túlio. O antiamericanismo de cátedra: desenvolvimento e nacionalismo no Brasil na década de 1950. Tese de Doutorado. Universidade de Brasília - Programa de PósGraduação em Relações Internacionais. Brasília, 2012.

FONSECA, Gelson. Mundos diversos, argumentos afins: aspectos doutrinários da política externa independente e do pragmatismo responsável. In: FONSECA, Gelson. A legitimidade e outras questões internacionais. São Paulo: Paz e Terra, 1998, p. 293-352.

FONSECA, Gelson. Política e terna brasileira: padrões e descontinuidades no período republicano. Relações Internacionais. mar., n. 29, p. 15-32, 2001.

FRANCO, Alvaro da Costa Franco (Org.). Documentos da política externa independente. Rio de Janeiro: Centro de História e Documentação Diplomática; Brasília: Fundação Alexandre de Gusmão, v. 1, 2007.

FRANCO, Alvaro da Costa Franco (Org.). Documentos da política externa independente. Rio de Janeiro: Centro de História e Documentação Diplomática; Brasília: Fundação Alexandre de Gusmão, v. 2, 2008.

FRANK, Robert; GIRAULT, René; THOBIE, Jack. La loi des géants 1941-1964. Paris: Masson, 1993.

FRIEDEN, Jaffrey. Capitalismo global: história econômica e política do século XX. Rio de Janeiro: Zahar, 2008.

FUKUYAMA, Francis. The end of history? The National Interest, v. 16, p. 3-18, 1989.

FUKUYAMA, Francis. The end of history and the last man. New York: The Free Press, 1992. 
GADDIS, John Lewis. History, science, and the study of international relations. In: WOODS, Ngaire (Ed.). Explaining international relations since 1945. New York: Oxford University, 2004, p. 32-48.

GADDIS, John Lewis. The Cold War. New York: Penguin Books, 2005a.

GADDIS, John Lewis. Strategies of containment: a critical appraisal of American National Security Policy during the Cold War. Oxford: Oxford University, 2005b.

GARCIA, Eugênio Vargas. Estados Unidos e Grã-Bretanha no Brasil: transição de poder no entreguerras. Contexto Internacional, v. 24, n. 1, p. 41-71, 2002.

GARCIA, Eugênio Vargas. Cronologia das relações internacionais do Brasil. 2. ed. Rio de Janeiro: Contraponto, 2005.

GARCIA, Eugênio Vargas. O sexto membro permanente: o Brasil e a criação da ONU. Rio de Janeiro: Contraponto, 2012.

GARDNER, Richard. Steling-dollar diplomacy: and Anglo-American collaboration in the reconstruction of multilateral trade. Oxford: Clarendon, 1956.

GOMES, Daniel. Oswaldo Aranha: prática e pensamento diplomático entre 1945 e 1960. Revista de Estudos Internacionais, v. 7, n. 1, p. 187-203, 2016.

GOMES, Daniel. Análise de política externa: um estudo sobre a ruptura das relações diplomáticas entre Brasil e República Popular da China e entre Brasil e União Soviética. Revista de Estudos Internacionais, no prelo.

GONÇALVES, Reinaldo. Custo econômico do mau governo Dilma Rousseff. IE-UFRJ Discussion Paper, Golçalves, TD 009|2016, 2016.

GREMAUD, Amaury; VASCONCELLOS, Marco; TONETO JÚNIOR, Rudinei. Economia brasileira contemporânea. 7. ed. São Paulo: Atlas, 2010.

GRIMMETT, Richard. Instances of use of United States armed forces abroad, 1798-2009. Congressional Research Service. Washington: Library of Congress, 2010.

GUDIN, Eugênio; SIMONSEN, Roberto. A controvérsia do planejamento na economia brasileira: coletânea da polêmica Simonsen x Gudin, desencadeada com as primeiras propostas formais de planejamento da economia brasileira ao final do Estado Novo. 3. ed. Rio de Janeiro: Instituto de Pesquisa Econômica Aplicada, 2010.

GUTHRIE-SHIMIZU, Sayuri. Japan, the United States and the Cold War, 1945-1960. In: LEFFLER, Melvyn; WESTAD, Odd (ed.). The Cambridge history of the Cold War. v. 1, Cambridge: Cambridge University, 2010, p. 244-265. 
HALLIDAY, Fred. The making of the Second Cold War. 2. ed. London: Verso, 1986.

HILTON, Stanley, The overthrow of Getúlio Vargas in 1945: diplomatic intervention, defense of democracy of political retribution? The Hispanic American Historical Review, v. 67, n. 1, p. 1-37, 1987.

HIRST, Mônica. O pragmatismo impossível: a política externa do segundo governo Vargas (1951-54). Rio de Janeiro: Fundação Getúlio Vargas, 1990.

HIRST, Mônica. A política externa do segundo governo Vargas. In: ALBUQUERQUE, José Augusto Guilhon (org.). Sessenta anos de política externa brasileira (1930-1990). São Paulo: Núcleo de Pesquisa em Relações Internacionais da Universidade de São Paulo/Cultura Editores Associados, 1996, v. 1, p. 211-230.

HITCHCOCK, William. The Marshall Plan and the creation of the West. In: LEFFLER, Melvyn; WESTAD, Odd (ed.). The Cambridge history of the Cold War. v. 1, Cambridge: Cambridge University, 2010, p. 1954-174.

HOBSBAWM, Eric. Age of extremes: the short twentieth century, 1914-1991. London: Abacus, 1995.

HULL, Cordell. The memoirs of Cordell Hull. 2v. New York: MacMillan, 1948.

HUNT, Michael; LEVINE, Steven. Revolutionary movements in Asia and the Cold War. In: LEFFLER, Melvyn; PAINTER, David. The origins of the Cold War: an international history. 2. ed. New York and London: Routledge, 2005, p. 251-264.

IBGE. Estatísticas Históricas do Brasil: séries econômicas, demográficas e sociais de 1550 a 1985. Rio de Janeiro: Fundação IBGE, 1987.

IKENBERRY, John. After victory: institutions, strategic restraint, and the rebuilding of order after major wars. Princeton: Princeton University, 2001.

JAGUARIBE, Hélio. Crises e alternativas da América Latina. São Paulo: Perspectiva, 1976.

KENNAN, George ("X"). The sources of Soviet conduct. Foreign Affairs, v. 25, v. 4, p. 566-582, 1947.

KORNIS, Mônica. Centro Dom Vital. In: Dicionário Histórico-Biográfico Brasileiro (1930-1983). 4v. Rio de Janeiro: Forense Universitária, 1984.

KRASNER, Stephen. Structural causes and regime consequences: regime as intervening variables. International Organization, v. 36, n. 2, p. 185-205, 1982. 
LAUFER, Rubén; RAPOPORT, Mario. Os Estados Unidos diante do Brasil e da Argentina: os golpes militares da década de 1960. Revista Brasileira de Política Externa, vol. 43, n. 1, p. 69-98, 2000.

LE CHAFFOTEC, Boris; MORELI, Alexandre. Countering war or embracing peace? Dialogues between regionalism and multilateralism in Latin America (1945-1954). Culture \& History Digital Journal, v. 4, n. 1, 2015.

LEOPOLDI, Maria Antonieta. O difícil caminho do meio: Estado, Burguesia e industrialização no Segundo Governo Vargas (1951-1954). In: GOMES, Angela de Castro (org.). Vargas e a crise dos anos 50. Rio de Janeiro: Relume-Dumará, 1994.

LESSA, Antônio Carlos; PENNA FILHO, Pio. O Itamaraty e a África: as origens da política africana do Brasil. Revista Estudos Históricos. Rio de Janeiro, n. 39, jan-jun, 2007.

LIGIÉRO, Luiz. A autonomia na política externa brasileira: a política externa independente e o pragmatismo responsável: momentos diferentes, políticas semelhantes? Brasília: Fundação Alexandre de Gusmão, 2011.

LIMA, Marcos Felipe Pinheiro. Do americanismo ao universalismo: as transformações nas relações internacionais do Brasil, de 1902 a 1964. Dissertação de Mestrado. Universidade de Brasília - Programa de Pós-Graduação em Relações Internacionais. Brasília, 2006.

LOURENÇO NETO, Sydenham. Relações Internacionais e burocracia: o Itamaraty antes e depois da segunda guerra mundial. In: XV Encontro Regional de História da ANPUH-RIO. Anais. São Gonçalo: Universidade Estadual do Rio de Janeiro, 2012.

LOURENÇO NETO, Sydenham. Raul Fernandes e a Diplomacia no Governo Dutra. In: $8^{\circ}$ Seminário Brasileiro de História da Historiografia. Anais. Ouro Preto: Universidade Federal de Outro Preto, 2014.

LUCA, Tania Regina de. O $1^{\circ}$ Congresso de Escritores e o arquivo Astrogildo Pereira. Cadernos do CEDEM, v. 1, p. 101-110, 2008.

LUNDESTAD, Geir. Empire by invitation? The United States and Western Europe, 1945-1952. Journal of Peace Research, v. 23, n. 3, p. 263-277, 1986.

MCMAHON, Robert. US national security policy from Eisenhower to Kennedy. In: LEFFLER, Melvyn; WESTAD, Odd (ed.). The Cambridge history of the Cold War. v. 1, Cambridge: Cambridge University, 2010, p. 288-311.

MAIER, Charles. The world economy and the Cold War in the middle of the twentieth century. In: LEFFLER, Melvyn; WESTAD, Odd (ed.). The Cambridge history of the Cold War. v. 1, Cambridge: Cambridge University, 2010, p. 44-66. 
MALAN, Pedro. Relações econômicas internacionais do Brasil (1945-1964). In: FAUSTO, Boris (dir.). O Brasil republicano. História Geral da Civilização Brasileira, tomo III, v. 4, 4. ed. Rio de Janeiro: Bertrand, 1995, p. 52-106.

MANZUR, Tânia. A política externa independente: antecedentes, apogeu e declínio. Lua Nova, São Paulo, v. 93, p. 169-199, 2014.

MARTIN, Elizabeth (ed.). A dictionary of law. 5. ed. Oxford: Oxford University, 2002.

MARTINEZ OLIVA, Juan Carlos. The Italian stabilization of 1947: domestic and international factors. Institute of European Studies. Berkeley: University of California, 2007.

MARTINS, André Saboia. Anotações sobre a intervenção na Guatemala em 1954: uma análise de suas projeções sobre as práticas sistemáticas de violação aos diretos de asilo e refúgio durante a Guerra Fria. Revista de Estudos e Pesquisas sobre as Américas, v. 10, n. 2, 2016, p. 1-28.

MARTINS FILHO, João Roberto. Forças Armadas e política, 1945-1964: a antessala do golpe. FERREIRA, Jorge; DELGADO, Lucilia (Org.). In: O tempo da experiência democrática: da democratização de 1945 ao golpe civil-militar de 1964. O Brasil republicano, v. 3. Rio de Janeiro: Civilização Brasileira, 2013, p. 97-126.

MCMAHON, Robert. The Cold War: a very short introduction. Oxford: Oxford University, 2003.

MCMAHON, Robert. US national security policy from Eisenhower to Kennedy. In: LEFFLER, Melvyn; WESTAD, Odd (ed.). The Cambridge history of the Cold War. v. 1, Cambridge: Cambridge University, 2010, p. 288-311.

MELlO, Celso de Albuquerque. Curso de direito internacional público. 15. ed. Rio de Janeiro: Renovar, v. 1, 2004.

MENDES, Lilian. Aliança e recompensa: a política de alinhamento do governo Dutra nos primórdios da Guerra Fria no Brasil. OPSIS, Catalão, v. 12, n. 2, p. 106-124, jul./dez, 2012.

MENDONÇA, Carlos Vinícius Costa De. Vicente Rao: um "intérprete das luzes" de São Paulo. Dimensões, Vitória, n. 4, p. 47-71, 1995.

MENDONÇA, Sônia Regina de. As bases do desenvolvimentismo capitalista dependente: da industrialização restringida à internacionalização. In: LINHARES, Maria Yedda (org.). História Geral do Brasil. 9. ed. 20. tiragem. Rio de Janeiro: Elsevier, 2000, p. 327-350.

MESSARI, Nizar; NOGUEIRA, João Pontes. Teoria das relações internacionais: correntes e debates. Rio de Janeiro: Elsevier, 2005.

MORENO, Julia. China contemporánea: 1916-1990. Madrid: Istmo, 1995. 
MOTTA, Rodrigo Patto Sá. O Perigo é Vermelho e vem de Fora: O Brasil e a URSS. Locus: revista de história, Juiz de Fora, v. 13, n. 2, p. 227-246, 2007.

MOURA, Gerson. Autonomia na dependência: a política externa brasileira de 1935 a 1942. Rio de Janeiro: Nova Fronteira, 1980.

MOURA, Gerson. O alinhamento sem recompensas: a política externa do governo Dutra. Rio de Janeiro: Fundação Getúlio Vargas, 1990.

MOURA, Gerson. Sucessos e ilusões: relações internacionais do Brasil durante e após a Segunda Guerra Mundial. Rio de Janeiro: Fundação Getúlio Vargas, 1991.

MOURA, Gerson. A segurança coletiva continental: o sistema interamericano, o TIAR e a guerra fria. In: ALBUQUERQUE, José Augusto Guilhon (org.). Sessenta anos de política externa brasileira (1930-1990). São Paulo: Núcleo de Pesquisa em Relações Internacionais da Universidade de São Paulo/Cultura Editores Associados. v. 1, 1996, p. 161-172.

MOURA, Gerson. Relações exteriores do Brasil: 1939-1950. Mudanças na natureza das relações Brasil-Estados Unidos durante e após a Segunda Guerra Mundial. Brasília: Fundação Alexandre de Gusmão, 2012.

NAIMARK, Norman. The Sovietization of Eastern Europe, 1944-1956. In: LEFFLER, Melvyn; WESTAD, Odd (ed.). The Cambridge history of the Cold War. v. 1, Cambridge: Cambridge University, 2010, p. 175-197.

PECHMAN, Robert. Raul Fernandes. In: Dicionário Histórico-Biográfico Brasileiro (1930-1983). 4v. Rio de Janeiro: Forense Universitária, 1984.

PINHEIRO, Letícia. Política externa brasileira: 1889-2002. Rio de Janeiro: Jorge Zahar, 2004.

PINHEIRO. Letícia. O Brasil no mundo. In: GOMES, Angela de Castro. Olhando para dentro (1930-1964). Madrid/Rio de Janeiro: Fundación Mapfre/Objetiva, 2013, p. 143-178.

PINHEIRO, Paulo Sério. Estratégias da ilusão: a revolução mundial e o Brasil (1922-1935). São Paulo, Companhia das Letras, 1991.

POLLARD, Sidney. International economy since 1945. London: Routledge, 1997.

PRENTZAS, G. S. The Marshall plan. New York: Chelsea House, 2011.

PUNTIGLIANO, Andrés Rivarola. Autonomía y geopolítica. In: RUIZ, José; SIMONOFF, Alejandro. Integración y cooperación regional en América Latina: una relectura a partir de la teoría de la autonomía. Buenos Aires: Biblos, 2015, p. 71-94. 
QUADROS, Jânio. Brazil's new foreign policy. Foreign Affairs, v. 40, n. 1, p. 19-27, 1961.

QUINTANEIRO, Tania. Dilemas da cooperação: conflitos gerados pela política das "Listas Negras" no Brasil durante a Segunda Guerra Mundial. Revista Brasileira de Política Internacional, v. 49, n. 2, p. 78-98, 2005.

RAJAK, Svetozar. The Cold War in the Balkans, 1945-1956. In: LEFFLER, Melvyn; WESTAD, Odd (ed.). The Cambridge history of the Cold War. v. 1, Cambridge: Cambridge University, 2010, p. 198-220.

RAMOS, Danielly. O Brasil e a República Popular da China: política externa comparada e relações bilaterais (1974-2004). Tese de doutorado. Universidade de Brasília - Programa de Pós-Graduação em Relações Internacionais. Brasília, 2006.

RECKZIEGEL, Ana. O fator norte-americano na crise do segundo governo Vargas. In: SIMPÓSIO NACIONAL DE HISTÓRIA, 24., 2007, São Leopoldo. Anais. São Leopoldo: Rio Grande do Sul, 2007.

RECKZIEGEL, Ana. A política nuclear brasileira e as relações internacionais: 1946-1957. In: SIMPÓSIO NACIONAL DE HISTÓRIA, 26, 2011, São Paulo. Anais. São Paulo: São Paulo, 2011.

RENOUVIN, Pierre. Historie des relations internationales. Paris: Hachette, 1953.

REZENDE, Renato Arruda de. 1947, o ano em que o Brasil foi mais realista que o rei: o fechamento do PCB e o rompimento das relações Brasil-União Soviética. Dissertação de Mestrado. Universidade Federal da Grande Dourados - Programa de Pós-Graduação em História. Dourados, 2006.

RICUPERO, Rubens. O Brasil, a América Latina e os EUA desde 1930: 60 anos de uma relação triangular. In: ALBUQUERQUE, José Augusto Guilhon (org.). Sessenta anos de política externa brasileira (1930-1990). São Paulo: Núcleo de Pesquisa em Relações Internacionais da Universidade de São Paulo/Cultura Editores Associados, 1996, v. 1, p. 37-60.

ROBERTON, David. The Routledge dictionary of politics. 3. ed. London, New York: Routledge, 2004.

RUGGIE, John. International regimes, transactions, and change: embedded liberalism in the postwar economic order. International Organization, v. 36, n. 2, p. 379-415, 1982.

RUIZ, José. Saber y teoría: reconstruyendo la tradición autonómica en los estudios de integración en América Latina. In: RUIZ, José; SIMONOFF, Alejandro. Integración y cooperación regional en América Latina: una relectura a partir de la teoría de la autonomía. Buenos Aires: Biblos, 2015, p. 29-70. 
SANCHÍS MUÑOZ, José. Historia diplomática argentina. Buenos Aires: Universidad de Buenos Aires, 2010.

SARAIVA, José Flávio Sombra. Dois gigantes e um condomínio: da guerra fria à coexistência pacífica (1947-1968). In: SARAIVA, José Flávio Sombra (org.). História das relações internacionais contemporâneas: da sociedade internacional do século XIX à era da globalização. São Paulo: Saraiva, 2008, p. 197-230.

SARAIVA, José Flávio Sombra. El concepto de autonomía decisoria en la política exterior brasileña: una creación propia del lugar de Brasil en el mundo. In: RUIZ, José; SIMONOFF, Alejandro. Integración y cooperación regional en América Latina: una relectura a partir de la teoría de la autonomía. Buenos Aires: Biblos, 2015, p. 221-242.

SARETTA, Fausto. A política econômica brasileira: 1946-1950. Revista de Sociologia e Política, v. 4/5, p. 113-129, 1995.

SAUVY, Alfred. Trois mondes, une planète. L'Observateur. 14 ago. 1952.

SCHWARCZ, Lilia Moritz; STARLING, Heloisa Murgel (2015). Brasil: uma biografia. São Paulo: Companhia das Letras.

SHERWOOD, Robert. Roosevelt e Hopkins: uma história da Segunda Guerra Mundial. Rio de Janeiro: Nova Fronteira; Brasília: Universidade de Brasília, 1998.

SILVA, Alexandra de Mello e. O Brasil no continente e no mundo: atores e imagens na política externa brasileira contemporânea. Estudos Históricos. Rio de Janeiro, v. 8, n. 15, p. 95-118, 1995.

SKIDMORE, Thomas. Brasil: de Getúlio Vargas a Castelo Branco, 1930-1964. 7. ed. Rio de Janeiro: Paz e Terra, 1982.

SPYKMAN, Nicholas. America's strategy in world politics: the United States and the balance of power. New York: Hartcourt, Bruce, 1942.

STALIN, Joseph. Speeches delivered at meetings of voters of the Stalin electoral district, Moscow: December 11, 1937 and February 9, 1946. Moscow: Foreign Languages Publishing House, 1954.

STEPHANSON, Anders. The Cold War considered as a US project. In: PONS, Silvio; ROMERO, Frederico (ed.). Reinterpreting the end of the Cold War: issues, interpretations, periodizations. Abingdon: Frank Cass, 2005, p. 52-67.

STUECK, William. The Korean War. WESTAD, Odd. The Cold War and the international history of the twentieth century. In: LEFFLER, Melvyn; WESTAD, Odd (ed.). The Cambridge history of the Cold War. v. 1, Cambridge: Cambridge University, 2010, p. 266-287. 
SUBSERVIENTE. In: HOUAISS, Antônio; VILLAR, Mauro. Dicionário Houaiss da língua portuguesa. 1. ed. Rio de Janerio: Objetiva, 2001, p. 2628.

SVARTMAN, Eduardo Munhoz. Oficiais do Exército brasileiro nos EUA: experiência, memória e incorporação seletiva de ideias nas décadas de 1930 e 40. In: XXV Simpósio Nacional de História. Anais. Fortaleza: Associação Nacional de História, 2009.

SVARTMAN, Eduardo Munhoz. Negociando a dependência: relações militares BrasilEstados Unidos no início da Guerra Fria. OPSIS, v. 14, número especial, p. 160-184, 2014a.

SVARTMAN, Eduardo Munhoz. Da II Guerra Mundial à Guerra Fria: conexões entre os exércitos do Brasil e dos Estados Unidos. Latin American Research Review, v. 49, n. 1, p. $83-103,2014 b$.

UNITED NATIONS. Yearbook of the United Nations 1946-47. New York: Department of Public Information, 1947.

UNITED NATIONS ENVIRONMENT POGRAMME. Global Environment Outlook 3: past, present and future perspectives. London: Earthscan Publications, 2002.

VAÏSSE, Maurice. Les relations internationales depuis 1945. Paris: Armand Colin, 2013.

VIANNA, Sérgio Besserman. Política econômica externa e industrialização, 1946-1951. In: ABREU, Marcelo de Paiva (org.). A ordem do progresso: dois séculos de política econômica no Brasil. 2. ed. Rio de Janeiro: Elsevier, 2014, p. 105-120.

VISENTINI, Paulo Fagundes. Relações internacionais do Brasil: de Vargas a Lula. São Paulo: Fundação Perseu Abramo, 1996.

VISENTINI, Paulo Fagundes. A projeção internacional do Brasil: 1930-2012. Rio de Janeiro: Elsevier, 2013a.

VISENTINI, Paulo Fagundes. Do nacional-desenvolvimentismo à política externa independente (1945-1964). FERREIRA, Jorge; DELGADO, Lucilia (Org.). In: O tempo da experiência democrática: da democratização de 1945 ao golpe civil-militar de 1964. O Brasil republicano, v. 3. Rio de Janeiro: Civilização Brasileira, 2013b, p. 217-240.

WATSON, Adam. The evolution of international society: a comparative historical analysis. London: Routledge, 1992.

WEATHERSBY, Kathryn. Stalin and the Korean War. In: LEFFLER, Melvyn; PAINTER, David. The origins of the Cold War: an international history. 2. ed. New York and London: Routledge, 2005, p. 265-282. 
WESTAD, Odd. The Cold War and the international history of the twentieth century. In: LEFFLER, Melvyn; WESTAD, Odd (ed.). The Cambridge history of the Cold War. v. 1, Cambridge: Cambridge University, 2010, p. 1-19.

WINKLER, Allan. The Cold War: a history in documents. New York: Oxford University, 2003.

WYATT-WALTER, Andrew. The United States and Western Europe: the theory of hegemonic stability. In: WOODS, Ngaire (Ed.). Explaining international relations since 1945. New York: Oxford University, 2004, p. 126-154.

I - Fontes primárias.

\section{a) $\mathrm{CPDOC} / \mathrm{FGV}$}

GV c 1944.08.17

GV c 1944.12.27

GV c 1944.09.08/1

GV c 1945.09.00/1

GV c 1945.11.25

GV c 1945.12.12/2

GV rem.s 1950.01.28

GV c 1951.02.19/1

GV c 1953.05.00/4

GV c 1953.11.16/2

GV c 1954.06.22/6

OA cp 1946.08.12

OA cp 1947.03.18

OA cp 1947.03.29

b) Jornais

O Globo, edição de 12 de outubro de 1931

Jornal do Brasil, edição de 29 de dezembro de 1942

Correio da Manhã, edição de 22 de fevereiro de 1945

Correio da Manhã, edição de 03 de março de 1945

Folha da Manhã, edição de 22 de outubro de 1947.

Tribuna da Imprensa, edição de 14 de junho de 1950.

c) Biblioteca da Presidência da República

Eurico Dutra, "Mensagem à Nação" (31 de dezembro de 1946). 
Eurico Dutra, "Mensagem ao Congresso Nacional" (15 de março de 1947).

Getúlio Vargas, "Discurso pronunciado ao receber, no Tribunal Superior Eleitoral, o diploma de Presidente da República" (27 de janeiro de 1951).

Getúlio Vargas, "Mensagem ao Congresso Nacional" (15 de março de 1951).

d) Leis, decretos, emendas constitucionais, constituições

BRASIL. Constituição da República dos Estados Unidos do Brasil de 1891. Diário do Congresso Nacional, Rio de Janeiro, 24/02/1891, p. 523, 1891.

BRASIL. Decreto $n^{0}$ 19.941, de 30 de abril de 1931. Diário Oficial da União, Poder Executivo, Rio de Janeiro, 06/05/1931, Seção 1, p. 7191, 1931.

BRASIL. Constituição da República dos Estados Unidos do Brasil de 1934. Diário Oficial da União, Poder Executivo, Rio de Janeiro, 16/07/1934, Seção 1, p. 1, 1934.

BRASIL. Lei constitucional $n^{\circ}$ 9, de 28 de fevereiro de 1945. Diário Oficial da União, Poder Executivo, Rio de Janeiro, 01/03/1945, Seção 1, p. 3313, 1945a.

BRASIL. Decreto-lei $\mathrm{n}^{\mathrm{o}} 7.586$, de 28 de maio de 1945. Diário Oficial da União, Poder Executivo, Rio de Janeiro, 28/05/1945, Seção 1, p. 9436, 1945 b.

BRASIL. Decreto-lei $\mathrm{n}^{\circ}$ 9.258, de 14 de maio de 1946. Diário Oficial da União, Poder Executivo, Rio de Janeiro, 16/05/1946, Seção 1, p. 7223, 1946.

BRASIL. Constituição dos Estados Unidos do Brasil de 1946. Diário Oficial da União, Poder Executivo, Rio de Janeiro, 16/09/1946, Seção 1, p. 13059, 1946 b.

SENADO FEDERAL. Decretos legislativos: volume I (1946-1948). Brasília: Senado Federal, 1974

c) Tribunal Superior Eleitoral

Partido Social Democrático. Programa de 1945. 14 de junho de 1945.

Partido Social Democrático. Compromisso. 18 de julho de 1945.

Partido Social Democrático. Estatuto de 1945. 6 de agosto de 1945.

Partido Trabalhista Brasileiro. Estatuto de 1947. 26 de julho de 1947.

TRIBUNAL SUPERIOR ELEITORAL. Dados estatísticos: eleições federal, estadual e municipal realizadas no Brasil a partir de 1945. v. 1. Rio de Janeiro: Departamento de Imprensa Nacional, 1950. 
TRIBUNAL SUPERIOR ELEITORAL. Dados estatísticos: eleições federais e estaduais realizadas no Brasil em 1950. v. 2. Rio de Janeiro: Departamento de Imprensa Nacional, 1952.

União Democrática Nacional. Estatuto de 1945. 20 de agosto de 1945.

União Democrática Nacional. Programa de 1945. 20 de agosto de 1945.

União Democrática Nacional. Compromisso. 26 de agosto de 1945.

d) Foreign Relations of the United States

123 Hurley, Patrick J: The Ambassador in China (Hurley) to President Truman. Washington, 26 de novembro de 1945.

832.24/1-446: The Secretary of State to the Ambassador in Brazil (Berle). Washington, 7 de fevereiro de 1946.

Telegrama 740.32112A/5-846: The Chargé in Brazil (Daniels) to the Secretary of State, 8 de maio de 1946.

Telegrama 840.00/6-1647: The Chargé in the United Kingdom (Gallman) to the Secretary of State. Londres, 16 de junho de 1947.

Telegrama 732.61/10-947: The Chargé in Brazil (Key) to the Secretary of State. Rio de Janeiro, 9 de outubro de 1947.

Telegrama 501.BB/10-947: The Acting Secretary of State to the Embassy in Brazil. Washington, 11 de outubro de 1947.

851.51/10-2447: The Ambassador in France (Caffery) to the Secretary of State. Paris, 24 de outubro de 1947.

832.6363/8-1948: Memorandum by Mr. I. G. Harman, Petroleum Division, to the Chief of That Division (Eakens). Washington, 19 de agosto de 1948.

Memorando 611.35/5-150: Memorandum by the Secretary of State to the President. Washington, 1 de maio de 1950.

Telegrama 832.00/1-1551: The Ambassador in Brazil (Johnson) to the Secretary of State. Rio de Janeiro, 15 de janeiro de 1951.

Memorando 832.00/1-2551: Memorandum by the Assistant Secretary of State for InterAmerican Affairs (Miller) to the Secretary of State. Washington, 25 de janeiro de 1951.

Telegrama 832.131/1-552: The Ambassador in Brazil (Johnson) to the Department of State. Rio de Janeiro, 5 de janeiro de 1952. 
Telegrama 832.00 TA/5-653: The Secretary of State to the Embassy in Brazil. Washington, 08 de maio de 1953.

S/S-NSC files, lot 63 D 251, NSC 162: Report to the National Security Council by the Executive Secretary (Lay). Washingotn, 30 de outubro de 1953.

S/S-NSC files, lot 63 D 351, NSC 144 Series: Memorandum by the Under Secretary of State (Smith) to the Executive of the National Council (Lay). Washington, 20 de novembro de 1953.

INR-NIE files, NIE-86: National Intelligence Estimate. Washington, 4 de dezembro de 1953.

Hagerty Diary, July 27, 1954: Eisenhower Library, James C. Hagerty papers (FRUS: 1952-1954, XV). Washington, 27 de julho de 1954.

e) Outras

Discurso de Dwight Eisenhower, chefe de Estado-Maior. do Exército dos Estados Unidos, proferido na Assembleia Constituinte do Brasil, em 9 de agosto de 1946. Diário da Assembleia. ano I, n. 125, 09/08/19946, p. 3966, 1946.

Dwight D. Eisenhower, "Text of Eisenhower Address on 'Famine or Feast' Defense Policy," in New York Times, September 26, 1952, Sec. A, 12. New York Times, edição de 26 de setembro de 1952, p. 12.

Harry Truman, "Recommendation for assistance to Greece and Turkey" (12 de março de 1947).

Harry Truman, "Rear platform and other informal remarks in Ohio" (11 de outubro de 1948).

Harry Truman, "The president's farewell address to the American people" (15 de janeiro de 1953).

João Neves da Fontoura a João Batista Luzardo, telegrama, Rio de Janeiro, 15 jun. 1946, AHMRE-B, 600(41), Cx. 216, Maços Temáticos Secretos.

MINISTÉRIO DAS RELAÇÕES EXTERIORES. Relatório. 1949.

MINISTÉRIO DAS RELAÇÕES EXTERIORES. Relatório. 1951.

MINISTÉRIO DAS RELAÇÕES EXTERIORES. Relatório. 1952.

UNITED NATIONS, General Assembly, Fifth Session, Official Records, 1950. 
ANEXO 01: formas de Estado semissoberano (MELLO, 2004, p. 381-385)

\section{Estado vassalo}

Etapa intermediária pelo qual passavam as províncias de um império antes de alcançarem independência. Entre as características do Estado vassalo, estavam a de respeitar os tratados internacionais acordados pelo Estado suserano e o fato de que, em geral, o Estado vassalo não participam das relações internacionais.

Exemplo: Romênia (1856-1878) como Estado vassalo do Império Otomano.

\section{Protetorado}

Há, nesse caso, a subordinação de um Estado (protegido) a outro (protetor). A capacidade de o Estado protegido atuar no âmbito internacional é determinada pelo instrumento jurídico que fixou o regime de protetorado.

Exemplo: Tunísia em relação à França (1881).

\section{Estado cliente}

Denominação utilizada para caracterizar os países da América Central que concederam, voluntária ou forçosamente, aos Estados Unidos a administração de um serviço público próprio a um Estado soberano, como alfândega, exército. Os Estados clientes não gozavam de plena liberdade para determinar sua política externa.

Exemplo: Haiti (1915).

\section{Estado satélite}

Situação semelhante à dos Estados clientes, mas em relação à União Soviética. As democracias populares sofriam servidões em prol da União Soviética, como armamentos e exército. Além disso, a União Soviética controlava a política externa dos Estados clientes.

Exemplo: Polônia (1952).

\section{Estado associado}

Figura jurídica que emerge de um processo de descolonização incompleto. Assim, Estados pequenos e subdesenvolvidos alcançam a independência, mas não têm meios para mantê-la. Dessa forma, mantêm alguma associação com o Estado do qual se separaram. Este encarrega-se da defesa e da política externa do Estado associado.

Exemplo: Ilhas Cook (1965) em relação à Nova Zelândia. 
ANEXO 02: lista de fundadores da sociedade "Amigos da América"

\section{NOME}

PROFISSÃO

\begin{tabular}{|c|c|}
\hline A. B. Cavalcanti & engenheiro \\
\hline A. Marlins Viana Estigarribia & engenheiro \\
\hline Augusto Tasso Fragoso & militar: General de Divisão \\
\hline Antônio Bastos & militar: Major \\
\hline Cândido Mariano da Silva Rondou & militar: General de Divisão \\
\hline Delso Mendes da Fonseca & militar: Tenente-Coronel \\
\hline Esther de Viveiros & profissão não identificada \\
\hline Fransisca Xavier Rondon & profissão não identificada \\
\hline Fernando de Melo Viana & advogado \\
\hline Heloísa Alberto Torres & profissão não identificada \\
\hline J. C. Horta Barbosa & militar: General de Divisão \\
\hline José Pio Borges de Castro & militar: Coronel \\
\hline João Marinho & médico \\
\hline João Marques dos Reis & advogado \\
\hline João Guedes da Fontoura & militar: General de Divisão \\
\hline Jefferson de Lemos & médico \\
\hline Joaquim B. Cavalcanti & dentista \\
\hline Ignácio Azevedo Amaral & professor, matemático, militar honorário \\
\hline Lafayette Cortes & professor \\
\hline Mario M. Fabião & médico \\
\hline Manoel Rabello & militar: General de Divisão \\
\hline Nilo Colonna dos Santos & engenheiro \\
\hline Odilon Braga & advogado \\
\hline Pedro Renault Castanheira & funcionário público \\
\hline Raymundo Sampaio & militar: General de Brigada \\
\hline Renato Barbosa Rodrigues Pereira & militar: Coronel \\
\hline Saint-Clair Antonino de Miranda Carvalho & médico \\
\hline
\end{tabular}




\begin{tabular}{|l|l|}
\hline Tarcilo Fabião Filho & funcionário público \\
\hline Vicente de Paulo Vasconcellos & militar: Coronel \\
\hline Washington Barbosa Rodrigues Pereira & engenheiro \\
\hline $\begin{array}{l}\text { Fonte: quadro elaborado pelo autor a partir da ata de registro oficial da sociedade "Amigos da América", } \\
\text { publicada no Diário Oficial [da União] de } 28 \text { de novembro de 1942, seção 1, p. 45-46. }\end{array}$
\end{tabular}

